Historic, Archive Document

Do not assume content reflects current scientific knowledge, policies, or practices. 


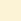




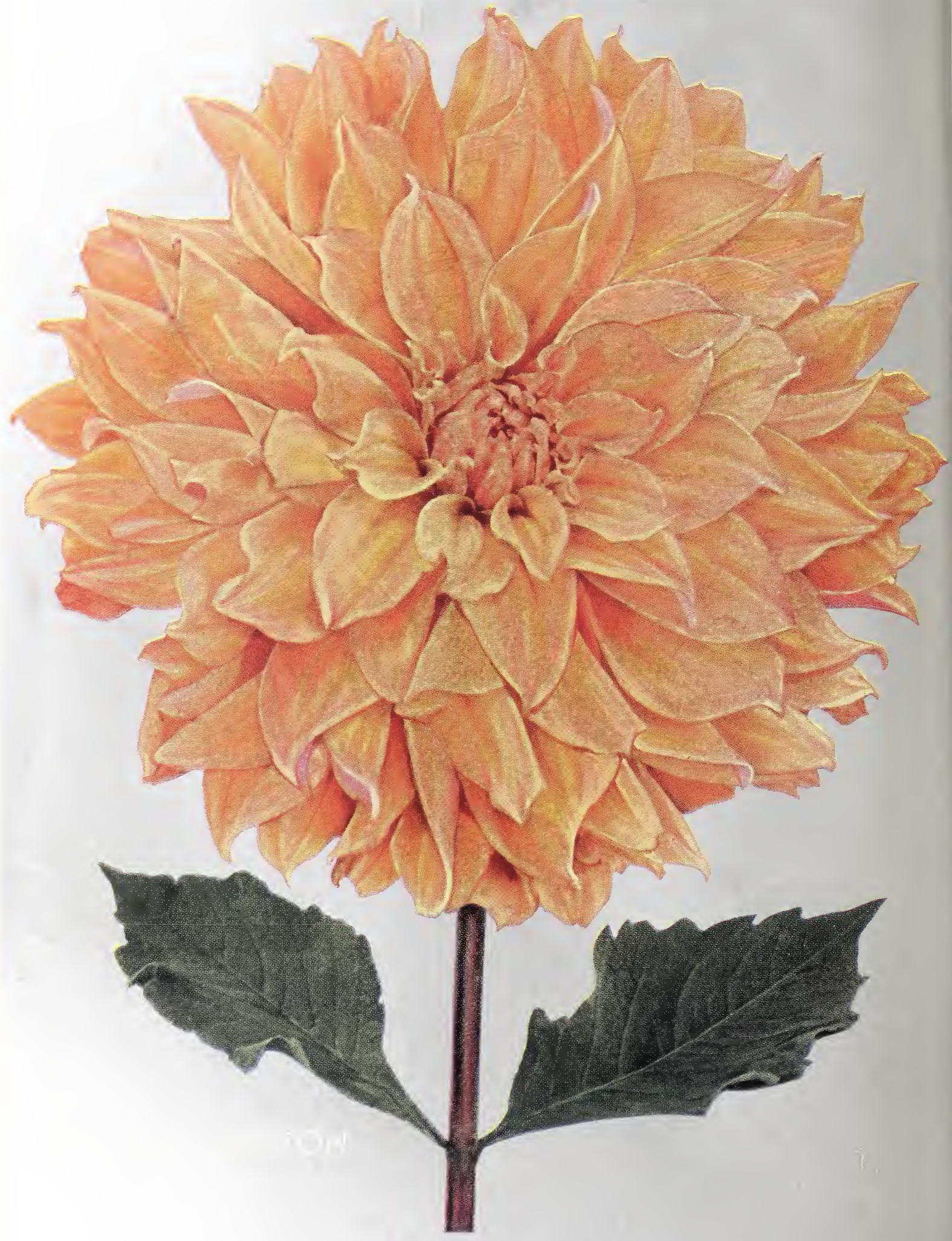




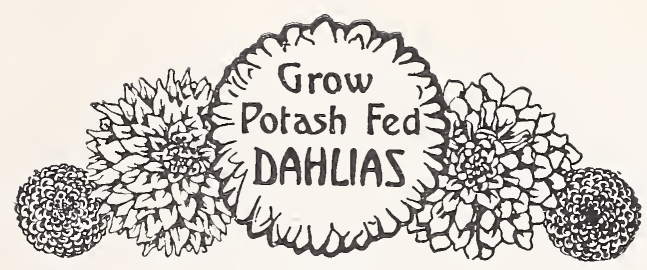

We certainly appreciate all the letters we have received telling us of the wonderful results our customers have had growing Potash Fed Dahlias. If testimonials were in keeping with our sales policy, we could fill a book, but we feel fully repaid for our effort in producing a super stock which is manifest by the universal satisfaction of our customers.

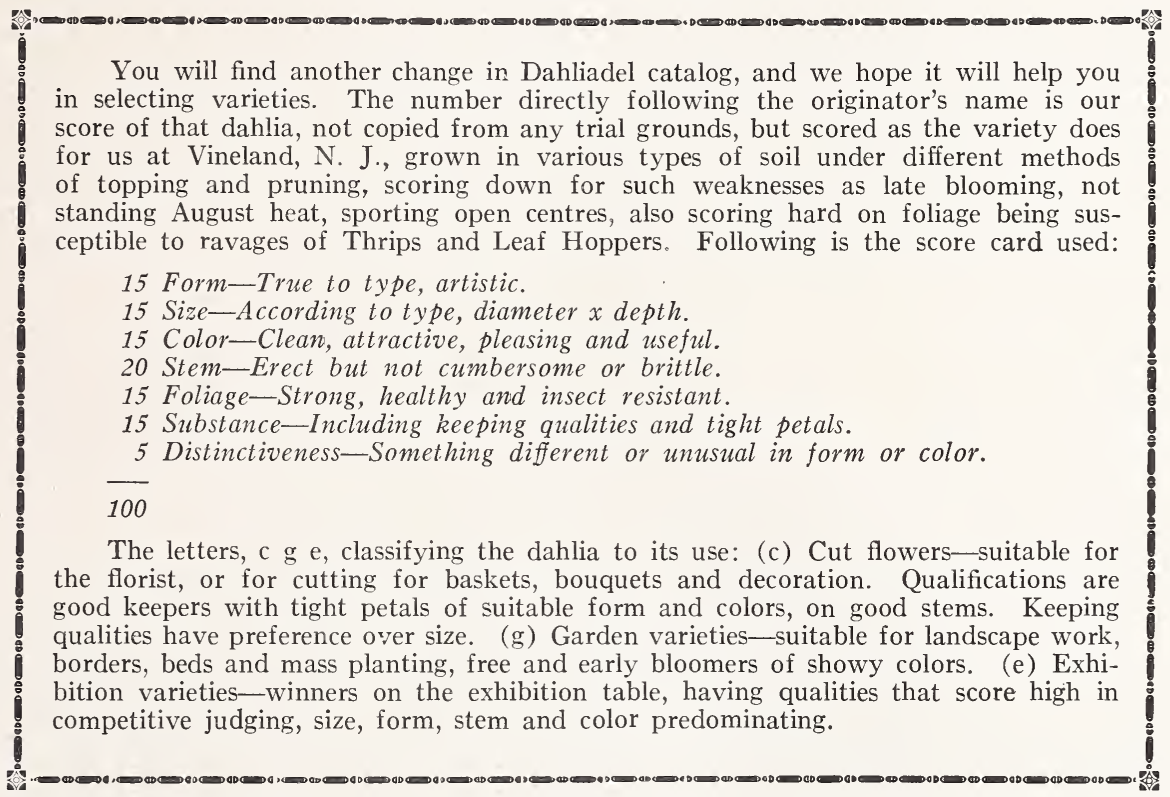

"Potash Fed Dahlias" is not a secret or just a trade name, but a modern method of growing dahlias so that they are literally alive with energy, making failure well-nigh impossible. Our whole object in producing such stock is so that you may reap the harvest of blooms, and our cultural directions scattered through the catalog are to aid you in growing them successfully.

The application of Potash in combination with the other elements necessary for proper plant growth (See Fertilizer), accompanied with the following conditions, will produce Potash Fed Dahlias.

First: Cultivation to aerate and sweeten the soil to keep the plant in a steady, healthy, growing condition. See Cultivating.

Second: Watering when necessary to make and keep the plant food available at all times. See Irrigation.

Third: Most important of all is the health of the stock from which your plants or tubers were grown. This condition has its ärect effect on the results obtained, for an unhealthy plant, whether stunted or diseased, cannot take up potash or any other element of plant food in sufficient quantities while in this debilitated condition. Hence, unhealthy or diseased plants cannot be "Potash Fed" even if grown in the midst of plenty.

If we were to say "Corn. Fed Pork," at once we would see the pig eating corn, but when we say "Potash Fed Dahlias," it is hard to visualize a dahlia feeding on potash, as it is something we cannot see. It is necessary to have the right food available when it is needed, and the animal or plant must be in a healthy state to make proper use of the food and give the results you are looking for.

CITY OF TRENTON (Prentice-Dahliadel). For description see page 6 . 


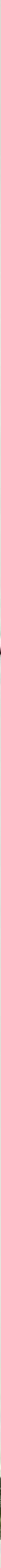

THOMAS A. EDISON

(DAHLIADEL) 


\section{Dahliadel Recommendations}

AMERICAN TRIUMPH (Nuneviller 85), 1930, c ge, Bloom $8 \times 4$, Bush $5 \mathrm{ft}$. Large Incurved Cactus of Oriental or bright, clear, rich red. Blooms are held rigid on long, straight stems, with high, full centres. Petals are decidedly incurved. Good garden and cut flower, as it is an exceptionally good keeper. Winner of The American Home Achievement Medal at New York.

Tubers, \$10.00; Plants, $\$ 5.00$

BOB WHITE (Dahliadel 89). See page 44.

CARDINALIS (Jas. Kennedy), 1930. Formal Decorative similar in form to Elite Glory. Color, brilliant cardinal red, that holds its color in the sunshine. Winner as best Undisseminated Seedling at Trenton and also a winner at Red Bank. One of the outstanding dahlias of the year.

Plants, $\$ 5.00$

CORA BUTTERWORTH (Chapman), 1930, $c g$ e. An Informal Decorative very similar to Waldheim Sunshine in form. Color, clear primrose yellow. Well-formed flowers produced on long, erect stems, a good, strong grower. Winner of best Undisseminated Seedling Decorative at New York. Tuber stock limited.

Tubers, $\$ 10.00 ;$ Plants, $\$ 5.00$

DAYLO (Nuneviller), 1930, $\mathrm{g}$ ge, Bloom $8 \times 4$, Bush 41/2 ft. This fine Formal Decorative scored 86 at Storrs this year, winning a Certificate of Merit. It is an open, vigorous grower with dark, leathery foliage. Color, a blending of cadmium yellow and orange.

Plants, $\$ 5.00$

DOROTHY STONE (F. \& M.), 1930, $c g$ e. This Informal Decorative is a true pink, a shade brighter than Kathleen Norris. It is distinct and a splendid exhibition companion for the latter. These very full blooms with thick petals are borne on strong, upright stems above deep green leathery foliage.

Tubers, $\$ 10.00 ;$ Plants, $\$ 5.00$

DOT (Dahliadel 89). See page 44.

ELIZA LONDON SHEPARD (Peacock 86), 1930, c g e, Bloom $9 \times 4$, Bush $51 \frac{1}{2} \mathrm{ft}$. Informal Decorative of a bright golden orange apricot so blended, making a one-tone spectacular flower. Blooms of good substance with full centres are borne on long, stiff stems. Strong, upright grower and free bloomer.

Plants, $\$ 10.00$

GOLDEN SONNE (De Wilde), $c \boldsymbol{g} \boldsymbol{e}$, Bloom $7 \times 4$. This Cactus is being introduced as a Holland Introduction, but we are quoting good authority when we say it was originated in New Jersey as Golden Sun. It is, however, a fine dahlia, especially as a cut flower and for exhibiting, where it has been a popular winner. Color, clear golden yellow, shading to soft salmon rose on the outside petals. A dahlia we can heartily recommend.

Plants, \$1.25

GOLD IMPERIAL (Hall), 1930, $g$ e. This Formal Decorative is a rich gold color with just a - tint of lavender on reverse. Petals heavy with a waxy appearance. Deep, graceful flowers with high, perfect centres. Vigorous grower. Won gold medal at Camden for best Undisseminated Seedling.

Plants, $\$ 5.00$

GOV. MORGAN F. LARSON (Hall), 1930, $g$ e. Won Governor's Cup at New Jersey State Show at Trenton as Most Worthy Undisseminated Dahlia. Also won as best yellow, cream or buff at Camden. Color, clear golden yellow with slight apricot blush on reverse. Very impressive Formal Decorative medium to tall growth, but sturdy plant. Plants, $\$ 5.00$ net

THOMAS A. EDISON (Dahliadel 88), 1930, g e, Bloom $9 \times 4 \frac{1}{2}$, Bush $4 \mathrm{ft}$. This gorgeous Formal Decorative, selected and named by permission of the famous electrical wizard, met with his complete approval when viewed at his West Orange estate. Furthermore, it has met with universal approval in the dahlia shows of 1929 and at our nursery in Vineland. The staghorn petal formation, the dark green insect-resistant foliage, the cane-stiff stems, and its thrifty growing habit leave nothing to be desired. In introducing it to a dahlia-loving public for 1930 , we do so with the knowledge that it is worthy of and will carry the usual Dahliadel guarantee, insuring its performance in your garden.

Plants only, $\$ 10.00$ 
HELEN IVINS (F. \& M.), 1930, $g e$, Bloom $9 \times 5$. This attractive Formal Decorative is a lively orchid lavender or deep orchid, holding its color throughout the season. It is a very free bloomer on good stems with tough leathery foliage.

Tubers, \$7.50; Plants, \$3.75

JERSEY'S TRIUMPH (Waite), 1930, c $g$ e, Bloom $8 \times 4$, Bush $5 \mathrm{ft}$. An attractive Formal Decorative Dahlia with fine, long stems for cutting. Color, bright copper suffused with salmonbronze. A seedling from Jersey's Beauty and a very attractive dahlia in the garden, having Beauty type bush, but more compact. Won in Seedling Class Open to All at Red Bank.

Tubers, \$10.00; Plants, $\$ 5.00$

LILAC GLORY (Ballego). A Holland variety that bids fair to be very popular, as it is a wellformed Incurved Cactus on exceptionally good stems. In color it is an even shade of bright rosy lilac.

Plants, $\$ 2.50$

MABEL DOUGLAS (Thompson), 1930. An Informal Decorative of Canadian Introduction that bids fair to become popular in the largest bloom class. Pastel lavender with long petals which curl gracefully. A variety that comes to us highly recommended.

Plants, $\$ 5.00$

MARGARET WYLIE (Fraser), 1930. Very artistic Informal Decorative. Immense loose-petaled blooms are beautiful shade of rose red, reverse of petals rose pink and silver. Profuse bloomer on long, stiff stems. Won at Connecticut Horticultural Society Show, Hartford, Conn., for Outstanding Seedling.

Tubers, $\$ 10.00$; Plants, $\$ 5.00$

MARIE (Peacock 81), 1930, c g e, Bloom 6 × 3, Bush 3 ft. A pink Formal Decorative with good centres. Medium dwarf grower and a splendid keeper when cut. Blooms are produced freely on strong, straight stems. This dahlia might be described as being the pastel counterpart of Pride of San Francisco.

Tubers, $\$ 5.00$; Plants, $\$ 2.50$

ORINDA (Newberry), 1930. Rich mauve pink without shadings or suffusion. Immense Formal Decorative held gracefully on long, stiff stems. Healthy grower and apparently insect and disease proof. Won the American Home Achievement Medal and Dahlia Society of New England Gold Medal at Boston for best New Dahlia and two other firsts.

Plants, $\$ 7.50$

PENN CHARTER (Hall), 1930, $g$ e. This Formal Decorative is a strong grower with heavy foliage. Blooms have great depth and beauty. Rich gold, tinted with reddish apricot. Massive, graceful flowers are held on long stems. A bright spot in your garden or home. Won as best Established Seedling at Philadelphia Show.

Plants, $\$ 5.00$

ROBERT E. LEE (Peacock 85), 1930, c g e, Bloom $81 / 2 x 4$, Bush $5 \mathrm{ft}$. A rich red that does not fade is decidedly uncommon and that is what attracts you to this Semi-Cactus Dahlia, along with its good form, erect stems, and free-blooming habits, making it an ideal cut flower and exhibition dahlia. Winner in Open to All Class at Camden as Best Red. Plants, \$10.00

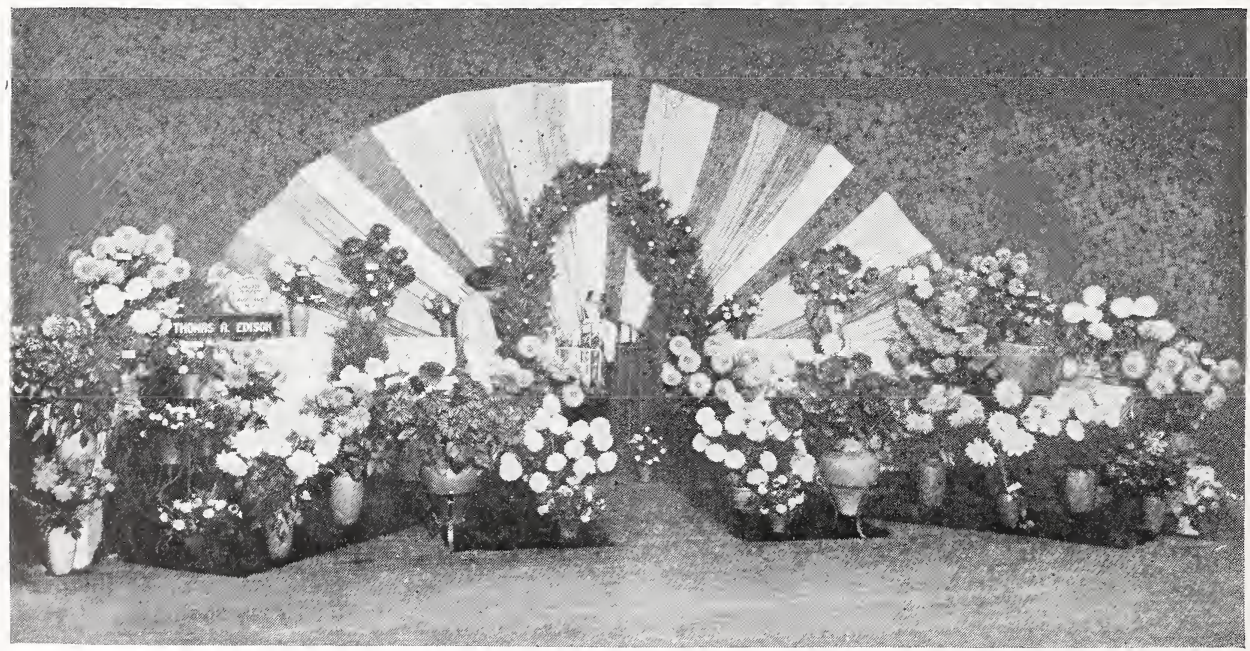




\section{DAHLIADEL NEWS}

The past year has marked more advancement than any year in Dahlia History. The scoring system is fast coming in favor from the elaborate system worked out by $\mathrm{Mr}$. Sweeney for trial grounds and seedlings, which is more for use of the professional than the novice, to the more simplified systems, such as explained on page 1 of this catalog.

New varieties introduced last year were far above the average. They are being selected for strength of growth and stem as well as the rest of the dahlia virtues, making it easier to grow exhibition dahlias each year. Then again, thousands of fans are feeding and caring for their dahlias scientifically, thanks to news articles, Dahlia Societies, catalogs and books on dahlias.

The National Association of Commercial Dahlia Growers, Inc., are doing a great work with their slogan, "Square Deal." This organization is stabilizing the dahlia industry with a systematic credit system and looking after complaints. Growers with a clean slate are hereby invited to send to Thomas Leavitt, Assinippi, Mass., for application blank for membership.

\section{DOINGS OF THE A. D. S.}

The American Dahlia Society have for once and all put an end to the argument of what is an Amateur. This has been solved by Classes A, B and C in the premium list of the 1929 New York Show, copy of these classes will be found on page 6 , as we believe they will be of interest to anyone exhibiting dahlias. Our Secretary, Wm. J. Rathgeber, 198 Norton Street, New Haven, Conn., will be glad to enroll you as a member of the A. D. S. Dues are $\$ 2.00$. The Bulletins issued quarterly are well worth the money.

On page 6 you will find a New Classification of the Dahlia made up by the Nomenclature Committee at a joint session with a Special Committee of the A. D. S., of which the writer had the pleasure of being a member. I personally believe it is a workable classification in which Class 1 has been opened to take in new types coming into prominence.

Classes 6, 7 and 8 divide the Cactus, very ably eliminating the word Hybrid, and making a rather definite line between Semi-Cactus and Informal Decorative. Where the majority of the floral rays are revolute or rolled back for less than half their length, we have a Semi-Cactus. When the floral rays are generally long, irregular in arrangement and usually twisted or pointed, we have the Informal Decorative. This classification should be interpreted to take dahlias that do not fit the Semi-Cactus Class.

The Miniature Decorative Class we favor very much and hope to soon have a set of Little Jewel in white, red, yellow and bronze.

Class 12 is for once rightly named Ball Dahlias, and Hybrid Show is no more.

\section{COMING EVENTS}

The movement is well under way to have one big Dahlia Bulletin or Magazine to cover the greater part of the United States. This seems to be the modern and logical solution to the excessive expense of each small society issuing their own. It will probably make uniform dues in all societies, and if you belong to your local society you will also belong to the A. D. S. through affiliation and receive the big Bulletin with the news of all the Societies. It is probable that each society will have space allotted for local news according to its membership or subscription, and that each society will be responsible for enough news to fill their allotment.

Another issue well worth considering is the use of a universal score card in Judging. It should not be at all complicated, so that the exhibitor as well as the Judge will fully understand it and one that can be used rapidly. No Judge is proficient until his mind is so organized to give each quality its right value. The score card should be kept in mind in all Judging and used in all close competition. Before installing this system be sure you have Judges who can use it.

\section{First National Atlantic City Flower and Garden Pageant}

\section{September 9 to 14,1930 , inclusive}

Atlantic City is this year staging a new sort of beauty pageant; a pageant of flowers; a pageant of beauty that promises to be the event of the year for garden lovers.

The first two days of the show will be devoted to the gladiolus as the feature flower, the second two days to garden flowers, while the final two days will glorify the dahlia. Commercial firms will maintain their exhibits for the entire six days, but the competitive exhibits will be staged on the days devoted to the respective flowers. The pageant will be held in the world's largest hall, the Atlantic City Auditorium, and will be financed and managed by the Auditorium, which is owned by the city.

Several State and local societies will make this the scene of their annual show, and while at this writing the plans for the pageant are not entirely complete, there is, however, at even this early date evidence enough that this will be the show of the year. Dahliadel will maintain the largest commercial exhibit in their history at this show during the six days and cordially invites their customers and friends to visit and compete for the many fine prizes that will be offered. It is expected that an advance premium list will be issued late in February, which may be had by writing J. W. Johnston, Director of the pageant, 383 Bourse Building, Philadelphia, Pa. 


\section{New Classification of the Dahlia}

CLASS 1. SINGLE DAHLIAS. Open-centred flowers with only one row of ray florets regardless of form or number of florets. For example, Newport Wonder, Fugi San, Eckford Century, Coltness Gem.

CLASS 2. ANEMONE DAHLIAS. Open-centred flowers with only one row of ray florets regardless of form or number of the florets, with the tubular disc florets elongated, forming a pin-cushion effect. For example, Ada Finch.

CLASS 3. COLLARETTE DAHLIAS. Open-centred flowers with only one row of ray florets with the addition of one or more rows of petaloids, usually of a different color, forming a collar around the disc. For example, Diadem, San Mateo Star, Ami Nonin, Geant de Lyon.

CLASS 4. DUPLEX DAHLIAS. Open-centred flowers with only two rows of ray florets regardless of form or number of florets. For example, Golden Sunshine, Mrs. J. Coissard.

CLASS 5. PEONY DAHLIAS. Open-centred flowers with not more than THREE rows of ray florets regardless of form or number of florets, with the addition of smaller curled or twisted floral rays around the disc. For example, Geisha, Gorgeous, City of Portland.

CLASS 6. INCURVED CACTUS DAHLIAS. Fully double flowers with the margins of the majority of the floral rays revolute for one-half or more of their length. The floral rays tending to curve toward the centre of the flower. For example, F. W. Fellows, Bearclaws, Farncot.

CLASS 7. RECURVED AND STRAIGHT CACTUS DAHLIAS. Fully double flowers with the margins of the majority of the floral rays revolute for one-half of their length or more, the floral rays being recurved or straight. For example, Ambassador.

CLASS 8. SEMI-CACTUS DAHLIAS. Fully double flowers with the margin of the majority of the floral rays revolute for less than one-half of their length. For example, Edna Ferber, Francis Lobdell, Sunkiss Alice Whittier.

CLASS 9. FORMAL DECORATIVE DAHLIAS. Fully double flowers, floral rays generally broad, either pointed or rounded at tips, with outer floral rays tending to recurve and central floral rays tending to be cupped; all floral rays in a somewhat regular arrangement. For example, Regal, Sagamore, Jersey's Beauty, Glory of Monmouth, Trentonian, Mrs. I. de Ver Warner, Judge Marean.

CLASS 10. INFORMAL DECORATIVE DAHLIAS. Fully double flowers, floral rays generally long, twisted or pointed and usually irregular in arrangement. For example, Ft. Monmouth, Jane Cowl, Barbara Redfern, Mrs. Alfred B. Seal, Insulinde, Kathleen Norris.

CLASS 11. MINIATURE DECORATIVE DAHLIAS. Fully double flowers, floral rays not revolute, conforming to the definitions for either the formal or informal decorative types, and less than three inches in diameter. For example, Little Jewel.

CLASS 12. BALL DAHLIAS. Fully double flowers, ball shape or slightly flattened, floral rays in spiral arrangement, blunt or rounded at tips and quilled or with markedly involute margins, two inches or more in diameter.

CLASS 13. POMPON DAHLIAS. Having same characteristics as Ball dahlias but less than two inches in diameter.

CLASS 14. UNCLASSIFIED DAHLIAS.

\section{Suggestions for Premium List Classifications}

SECTION A-For those other than professional gardeners who grow less than 100 hills exclusive of pompons and seedlings; do their garden work except soil preparation and do not sell tubers, plants or cut flowers.

SECTION B-For those other than professional gardeners who grow less than 250 hills exclusive of pompons and seedlings; do their own garden work except soil preparation and do not sell blooms or plants but are allowed to sell surplus tubers.

SECTION C-For those other than professional gardeners who grow Dahlias for pleasure, selling surplus stock, issuing none other than a non-descriptive price list and using the sales of the Dahlias as a side line and not posing as a commercial grower and buying at wholesale from other growers.

CITY OF TRENTON (Prentice-Dahliadel 86), $g$ e, Bloom $10 x 4, B$ sh $6 \mathrm{ft}$. This wonderful new decorative has all the qualifications of a first-class exhibition dahlia. It is impossible to portray the sheen and luster or the brightness in the color reproduction, but it will give you a general idea. The bush grows strong and robust, producing flowers with perfectly full centres on long, erect stems. A dahlia that will go beyond your expectation. D. S. of N. J. Cert. 


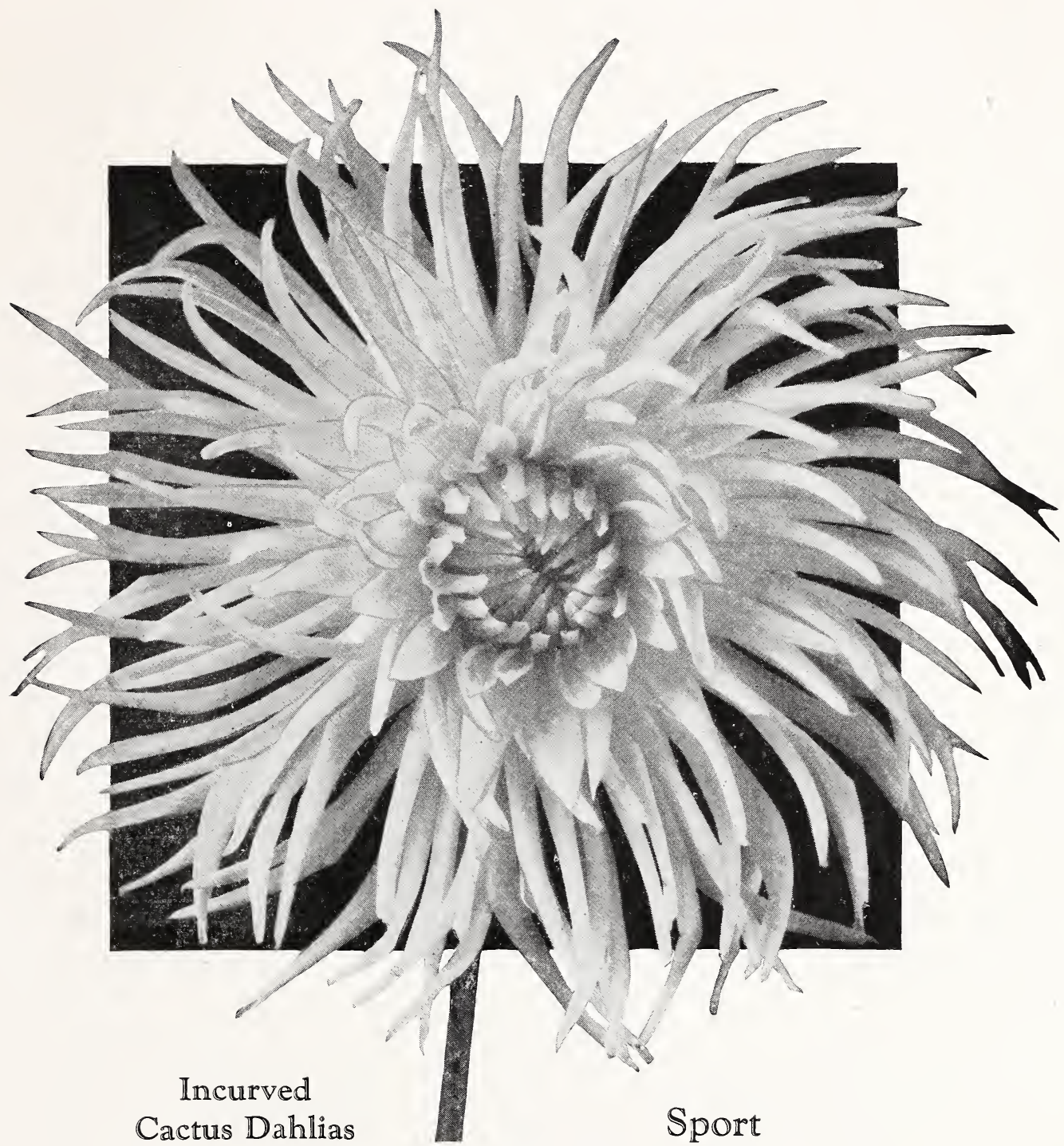

The dahlias in this group are commonly known as English Cactus. A characteristic of this type is a slender, wiry stem, not always holding the flower erect.

BALLET GIRL (Boston 78), $g$ e, Bloom $8 \times 3 \frac{1}{2}$, Bush 41/2 ft. Beautiful flowers of immense size. Color, orange, tipped white. Some flowers pure orange, with other variations on same bush. Early and free bloomer.

F. W. FELLOWS (Stredwick 80), g e, Bloom $8 \times 3 \frac{1}{2}$, Bush $51 / 2 \mathrm{ft}$. Still a favorite on the exhibition table. Flowers are of an ideal cactus form. Color, lively orange scarlet.

.75

SPORT (Dahliadel 82), $g$ e, Bloom $8 \times 3 \frac{1}{2}$, Bush $51 / 2 f t$. As its name indicates, it is a sport of F. W. Fellows with all its merits, but a pleasing shade of deep buttercup yellow with buff shadings at centre. This variety has never reverted to its parent. A wonderful exhibition flower and a favorite in the garden. 


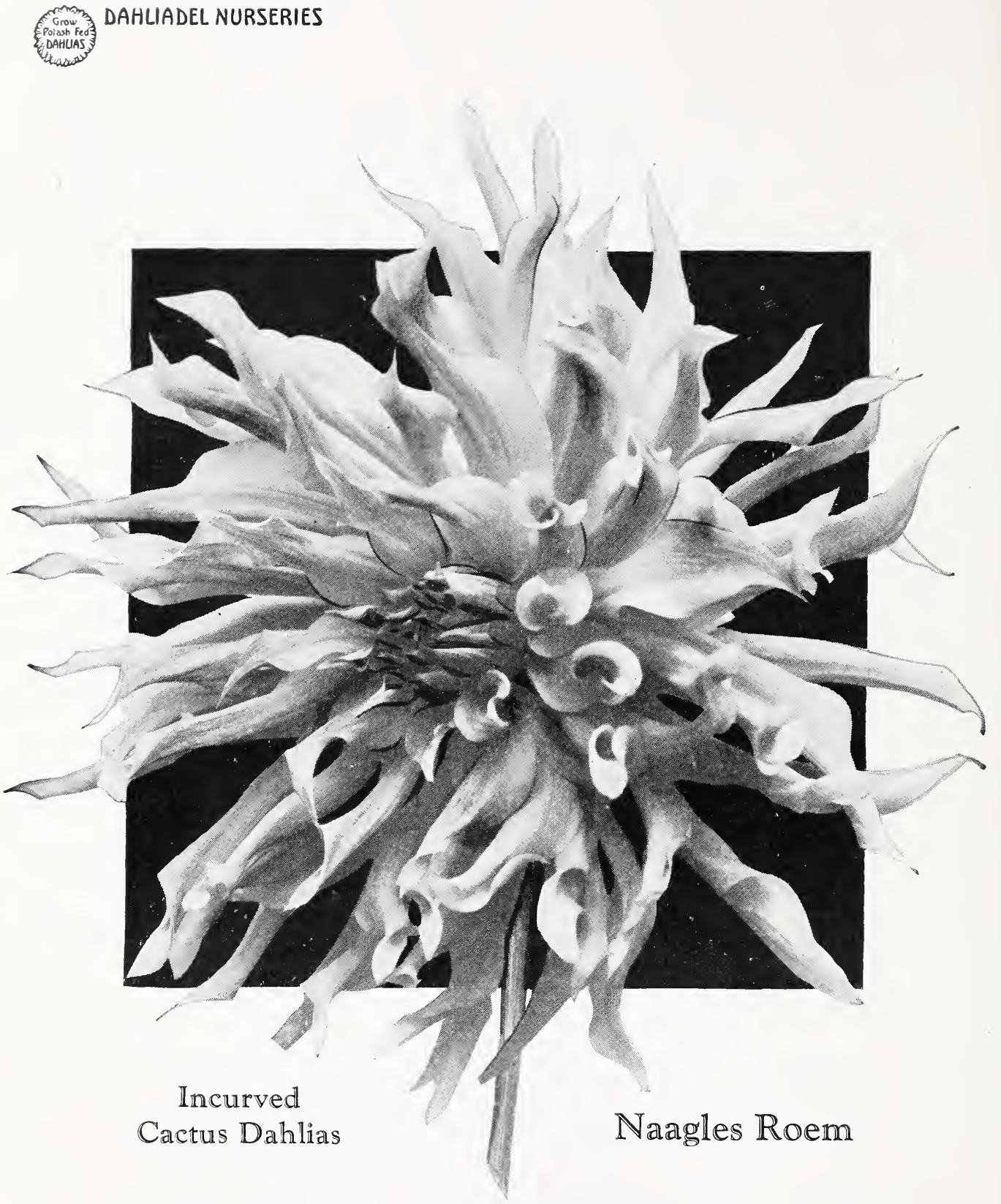

NAAGLES ROEM (Naagles 85), c g e, Bloom $7 \times 4$, Bush $51 / 2 f t$. The most popular of Europe's recent introductions. A distinctive cactus of regular formation. Excellent stems and one of the best keeping dahlias when cut, as it just goes on growing in water. Color, buff yellow, tipped rose.

$\$ 1.00$

EAGLE ROCK JEWEL (Broomall 83), $g$ e, Bloom $9 \times 4$, Bush $51 / 2 f t$. This is truly a beatitiful color combination of cream overlaid cameo pink. Flowers are large and borne on strong stems. Bush is healthy and upright. Centres full.

Tubers, $\$ 5.00$; Plants, $\$ 2.50$

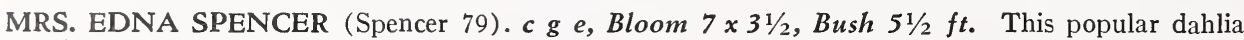
for shipping and keeping qualities is one of the very best. Flowers produced profusely on erect stems. Color, pale lilac, shading lighter at centre. 


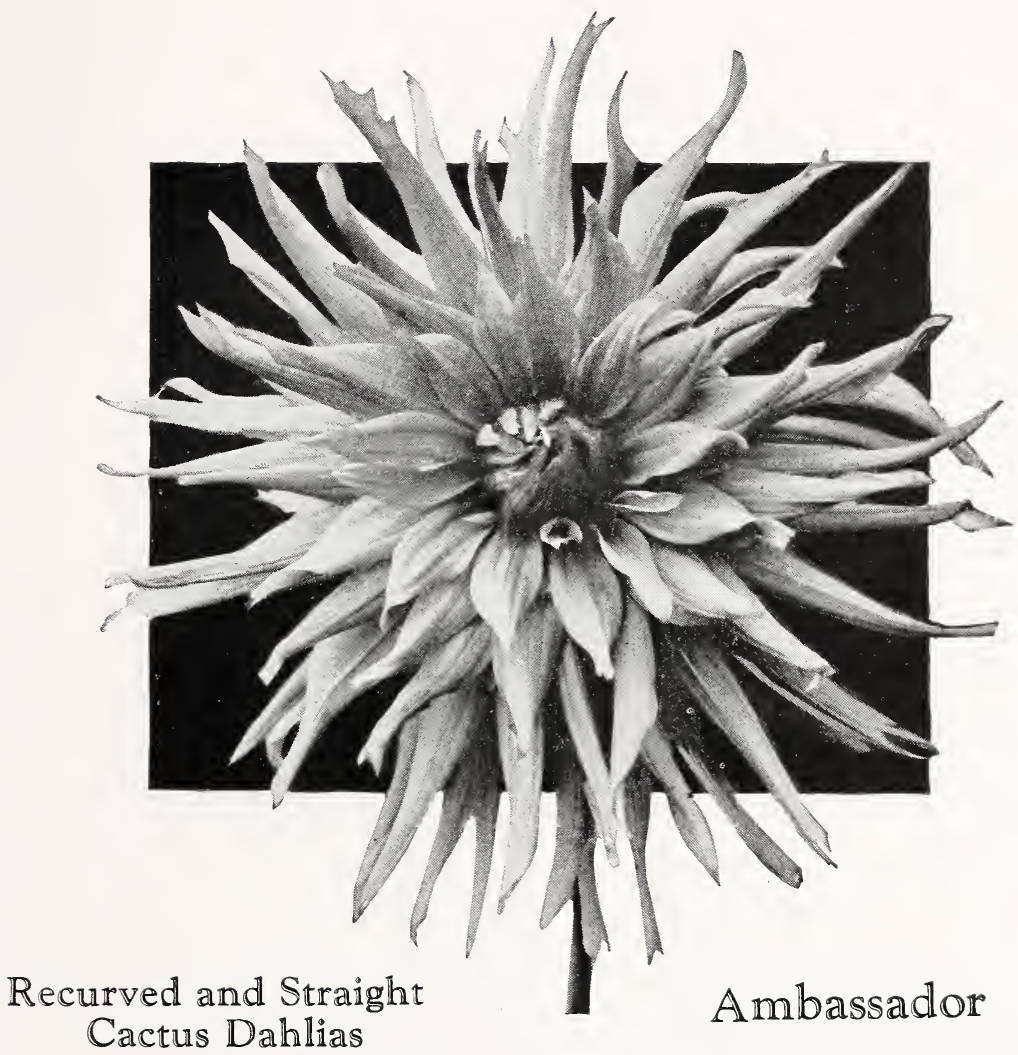

AMBASSADOR (Broomall 85), $\mathrm{c} g$ e, Bloom $8 \times 4$, Bush $5 \mathrm{ft}$. This fine flower is very popular at the dahlia shows. Color, soft yellow buff, shaded salmon pink. Well-formed flowers, held erect above the foliage. Bushes branch readily and produce a multitude of flowers. .75

ANDREAS HOFFER (Holland 80), c g, Bloom $6 \times 3$, Bush $4 \frac{1}{2} \mathrm{ft}$. Ideal form with narrow petals of a delicate pink with salmon suffusion, passing to a creamy white centre. A free bloomer on long, stiff, wiry stems.

$\$ 1.00$

CONQUISTADOR (Balley 88), 1929, g e, Bloom $10 \times 6$, Bush $6 \mathrm{ft}$. A massive dahlia with coarse, broad petals of a soft, creamy yellow shading to a glowing pink at base of petals. Pink coloring gives an illuminated effect from within. Plant is tall and vigorous. An improved and enlarged Ambassador with petals somewhat heavier.

Tubers, $\$ 7.50$; Plants, $\$ 3.75$

EAGLE ROCK GEM (Broomall 84), 1928, g e, Bloom $8 \times 4$, Bush $5 \mathrm{ft}$. This well-formed dahlia is unusual because of its color of maize yellow shaded orient pink. Long, erect stems. Good growing habits and an exceptionally free bloomer.

Tubers, $\$ 7.50$; Plants, $\$ 3.75$

MARIAN BROOMALL (Broomall 87), g, e, Bloom $10 \times 4 \frac{1}{2}$, Bush $5 \mathrm{ft}$. A truly beautiful dahlia. Color, clear light lilac, shading lighter at tips with white centre. Bush growth and stems very good. A dahlia you will like.

Tubers, $\$ 2.00$; Plants, $\$ 1.00$

MIRAFLORA (Broomall 80), $g$ e, Bloom $10 \times 4$, Bush 41/2 ft. Although this dahlia, owing to its light, graceful formation, looks frail, it is a wonderful keeper when cut. Bush is rather dwarf, with stems long and erect. Color, white tinted violet pink.

$\$ 1.00$

SILVERADO (Seal 83), g e, Bloom $9 \times 4$, Bush $6 \mathrm{ft}$. Immense blooms of white, gradually shading toward the centre to a delicate silvery lavender. The stems are extra long, but not always erect. The well-branched bushes are always covered with blooms. Tubers, \$3.00; Plants, \$1.50 


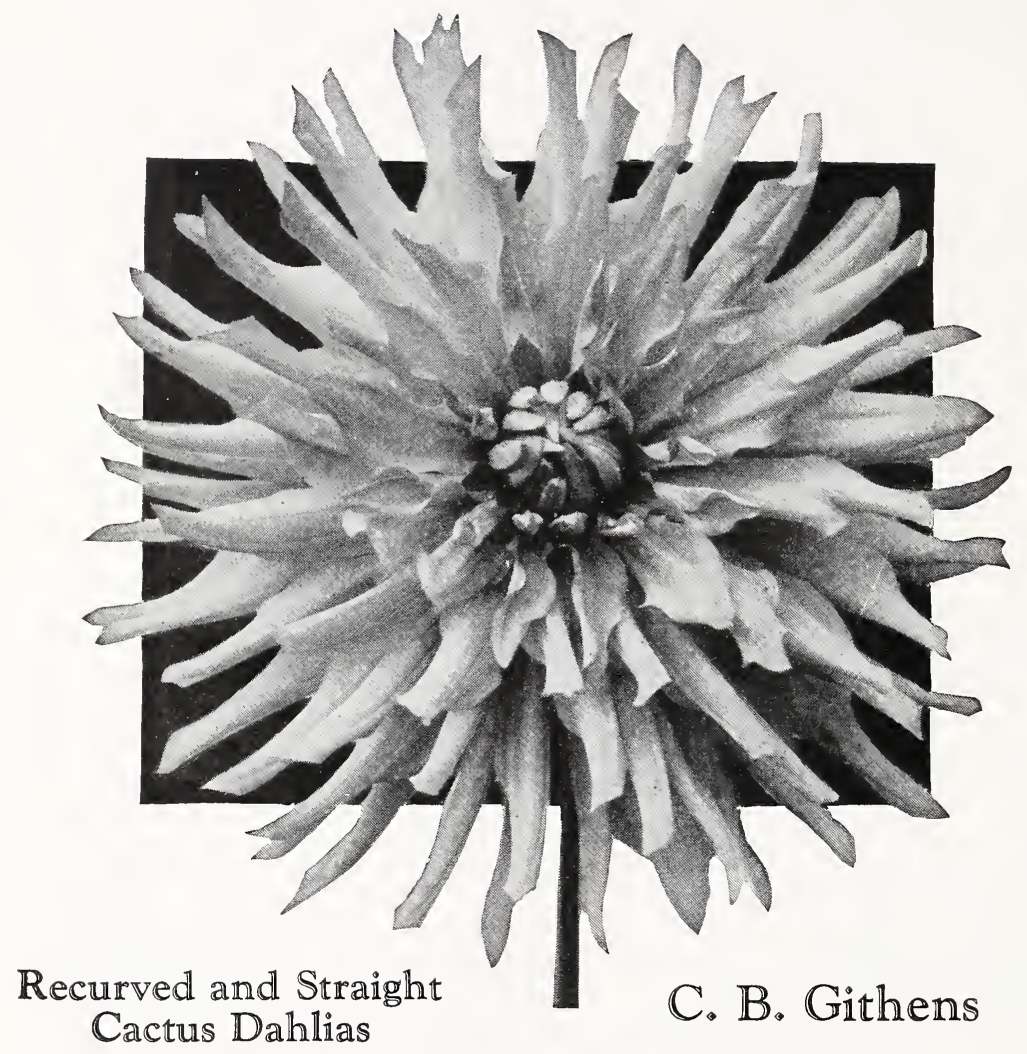

C. B. GITHENS (Peacock 80), c g e, Bloom $7 \times 3^{1 / 2}$, Bush $5 \frac{1}{2} f$ t. One of the best clear yellow cactus dahlias we grow. Produces well-formed flowers of good substance and keeping qualities, on long, slender but stiff stems. Valuable for exhibition and as a commercial.

ADDA PATTERSON (Kemp 82), c g e, Bloom $8 \times 4$, Bush $61 / 2 f t$. We believe it to be the best pure white of its type. Flowers are large, of a splendid, even form, on long, erect stems. A wonderful exhibition variety on account of its keeping qualities, along with its size, stem and form.

Tubers, \$2.50; Plants, $\$ 1.25$

CALIFORNIA BEAUTY (Broomall 81), c g e, Bloom $7 \times 3 \frac{1}{2}$, Bush $4 \frac{1}{2}$ ft. A pure copper in color. We have found this variety to be one of the best keepers as a cut flower, and we have never had enough for the market. Bush growth and stem excellent.

ELLA MAY (Prentice-Dahliadel 86), g e, Bloom $8 \times 5$, Bush $5 \mathrm{ft}$. We seldom find a pure cactus with a real good stem, but that is what we have in this dahlia. Flowers are large and deep, with full centres and a deep rich crimson carmine, dark and yet rich. Bush is a good open grower. A dahlia that is decidedly distinctive.

Tubers, $\$ 3.00$; Plants, $\$ 1.50$

FAIR ELAINE (Balley 84), 1929, $c$ g e, Bloom $9 \times 3$, Bush, 6 ft. This dahlia may be described as an improved Nibelungenhort. Delicate old rose with golden illumination. Numerous branches produce quantities of well-formed blooms.

Tubers, \$7.50; Plants, \$3.75

FORDHOOK CRAWFISH (Burpee 80), c g e, Bloom $7 \times 3 \frac{1}{2}$ Bush $6 \mathrm{ft}$. This appealing, wellformed flower is a violet rose, shading lighter, with a white centre, keeping well when cut. Stems are long and stiff, bush growth healthy. A. D. S. Cert. Tubers, $\$ 2.00 ;$ Plants, $\$ 1.00$ 


\section{RECURVED and STRAIGHT CACTUS DAHLIAS-Continued}

FORDHOOK PEARL (Burpee 80), $g$ e, Bloom $8 \times 4, B u s h ~ 41 / 2 f t$. This artistic hybrid cactus is an early, free and continuous bloomer, holding a full centre through the season. Outer petals are straight, while the centre petals twist gracefully. A clear primrose yellow, shading to a deep creamy white at the tips. Stems are long when disbudded. D. S. of N. J. Cert.

Tubers, $\$ 2.00 ;$ Plants, $\$ 1.00$

GLADYS BATES (Boston 81), c $g$ e, Bloom $8 \times 3 \frac{1}{2}$, Bush $4 \frac{1}{2} \mathrm{ft}$. A huge cut flower of perfect form. Color, tan with rose reverse. A dahlia of real merit, especially in the early season.

.50

IAN (Boston 82), $g$ e, Bloom $8 \times 4, B u s h 51 / 2 f t$. A giant of the incurved English form, but with heavier petals of unusual coloring and exceptionally good form. Color, very clear yellow, gradually shading to pink on the outer petals, while reverse of these petals reveals a golden suffusion. Flowers occasionally show a white tipping. Blooms freely on good stems, making it very desirable for cutting and exhibiting.

Tubers, $\$ 2.00$; Plants, $\$ 1.00$

JEAN CHAZOT (Cayeux 79), g, Bloom 71/2 $\times 4, B u s h ~ 51 / 2 ~ f t$. Flowers of graceful formation. Color, orange suffused gold, frequently tipped golden yellow. The tall, branching bushes hold the large blooms gracefully on straight stems.

.75

KALIF (G. \& K. 83), g e, Bloom $9 \times 4$, Bush 5 ft. Color, rich strawberry red or carmine. The mammoth flowers are borne in great profusion. An old favorite and a good cut flower. Base of petals broader than illustration.

MAHOGANY (Murphy 80), $g$ e, Bloom $9 \times 4, B$ Bsh 41/2 ft. A dark red American Cactus on a good, erect stem. Large flowers of good form with full centres. Dark velvety red with a lighter reverse.

MOTHER (Peacock 78), c g, Bloom 51/2 $\times 3$, Bush 41/2 ft. A fine white on erect stems, which are well supplied with healthy green foliage. Bush sturdy. A continuous bloomer. $\$ \mathbf{\$ 1 . 0 0}$

MRS. E. F. T. SMITH (Broomall 74), g, Bloom $91 / 2 \times 3$, Bush 6 ft. Immense flowers held well above the foliage on strong stems. Color, creamy white, shading to lemon tint at centre. Petals broader at the base than illustration. A strong grower.

NIBELUNGENHORT (G. \& K. 76), g, Bloom $7 \times 2 \frac{1}{2}$, Bush 5 ft. An old favorite violet rose suffused golden apricot. Very profuse, early and colorful.

SISKIYOU (Broomall 80), $g$ e, Bloom $10 \times 3, B$ sh $31 / 2 f t$. Here we have the dahlia that has won in the largest bloom class repeatedly, but on diameter, not considering depth. Flowers he,id erect on long, strong stems. Color, pink tinted mauve. Petals rather blunt and flat.

Tubers, \$1.50; Plants, $\$ 1.00$

\section{Green Plants}

Dahliadel plants are cuttings taken from stock of named varieties, grown in specially built greenhouses, rooted in sand benches in a special propagating house for that purpose, potted and grown inside until established, then moved to cold frames for hardening off, ready for shipping and field planting.

The popularity of Dahliadel Green Plants is growing fast, and we suggest that you give them a trial on your next order if you are buying the higher-priced varieties, as plants are one-half tuber price in most cases. Green plants, when properly grown from healthy stock, give equal or better blooms than from tubers, and make a nice clump in most varieties. The way the plant is grown has a lot to do with tuber production, but we believe by following our cultural instructions you will have tubers as well as blooms.

Where dahlia plants are grown without much fertilizer or water they are apt to make more tubers than when grown in the midst of plenty. To produce tubers on plants use a balanced plant food but not to excess, water only when necessary. After the plants are well started (or about six weeks after planting) or at least six weeks before you want blooms, cut bushes back severely, leaving about one-half the growth and not more than six laterals for the first blooms. This will give the plant an over-supply of feed roots, which will start tuber production at once. On digging in the fall you will find mature tubers, where on (check) plants not cut back you will find mostly fibrous or feed roots.

In growing Dahliadel Green Plants, only the strongest cuttings are potted, and again the best plants are selected for filling orders. This assures you of the best stock procurable. 


\section{DAHLIADEL NURSERIES}

Eotanh Fed

DAHUASY

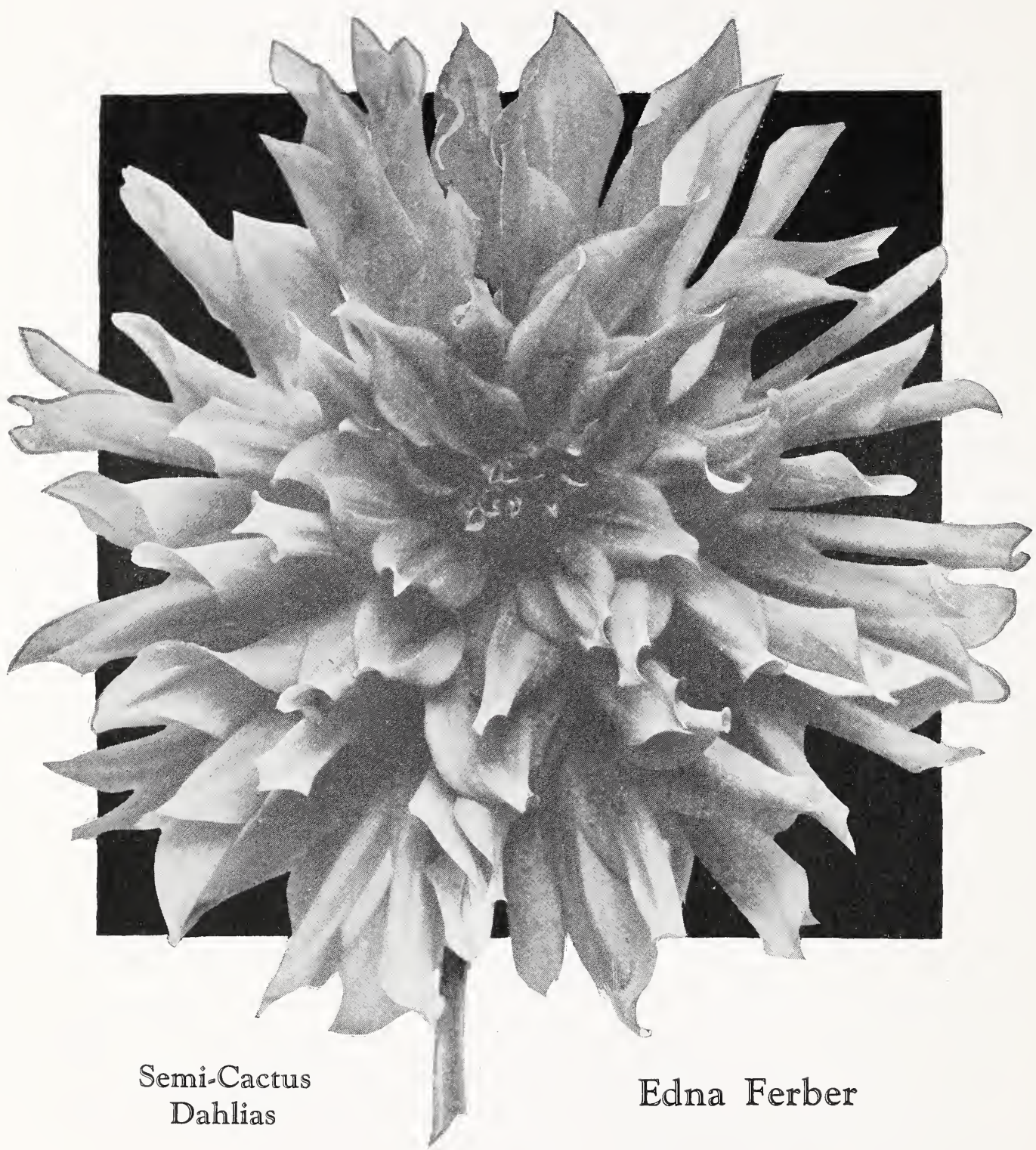

EDNA FERBER (F. \& M. 89), c g e, Bloom $9 \times 4$, Bush 5 ft. The extreme size and beauty of this flower attract attention wherever shown. The petals are curled and twisted, forming an extremely full flower held erect on fine stems. Color, glistening coral, shading to old gold at base of petals. A good, strong grower with dark green foliage. D. S. of N. J. Cert.

Tubers, $\$ 3.00$; Plants, $\$ 1.50$

A. A. STIVERS (Boston), 1929, $g$ e, Blooms $8 x 3$, Bush $51 / 2 ~ f t$. Amber-shaded rose with creamy tan centre. A Semi-Cactus with incurved petals, somewhat distinctive in coloring, of good form on long stems, keeping well when cut.

Plants, $\$ 5.00$ 


\section{SEMI-CACTUS DAHLIAS-Continued}

ALICE WHITTIER (Reed 82), $g$ e, Bloom $10 \times 5$, Bush $7 \mathrm{ft}$. One of the largest and finest primrose yellow semi-cactus dahlias for exhibition, on good stems. A. D. S. and The D. S. of N. J. Cert.

Tubers, $\$ 2.00$; Plants, $\$ 1.00$

DADDY BUTLER (Boston 80), g e, Bloom $7 \times 4$, Bush $6 \mathrm{ft}$. An early, profuse bloomer and good keeper on perfect stems. Color, rosy carmine, reverse of petals lighter.

MARIPOSA (Boston 83), c g e, Bloom $8 \times 4$, Bush $6 \mathrm{ft}$. This popular flower is of great depth, perfect form, with incurved petals. A beautiful pink, shading darker at the centre with a violet suffusion, which adds to the effect. A sturdy grower and great favorite.

.75

PAULINA (Hall 80), g e, Bloom $8 \times 3 \frac{1}{2}$, Bush $51 / 2 f t$. This dahlia grows to exhibition size on long, strong stems. It is an early and abundant bloomer with full-centred flowers. Color is a light orange suffused with amaranth pink on the reverse.

Tubers, $\$ 2.00$; Plants, $\$ 1.00$

SANTA ANNA (Pelicano 83), $g$ e, Bloom $9 \times 4$, Bush $6 f t$. This fine variety is of an artistic formation with petals curled and twisted, while the color is a beautiful salmon rose suffused with old gold. Plant is a good grower with large flowers held well above the foliage on good stems. Classified as a Hybrid Cactus in the West, but very similar to the accompanying illustration for us.

Tubers, $\$ 2.50$; Plants, $\$ 1.25$

SUNKISS (Yezek 82), c g, Bloom $8 \times 4$, Bush 51/2 ft. A truly pastel combination of straw yellow with a heavy fawn suffusion on the outer edge, making it a universal favorite. A free and early bloomer on fine stems, making it very desirable for cutting.

$\$ 1.00$

\section{ALL THE ABOVE VARIETIES ARE THE SAME FORM AS ILLUSTRATION}

\section{Planting Directions}

The following directions are based upon years of practical experience and may be of value in solving some of your cultural problems. These suggestions should be changed to suit the local requirements. However, we sincerely believe that the fundamental principles. involved will apply throughout the country.

\section{Care of Green Plants}

After removing moss and paper pots from plants that have been shipped, plant them with the top of the ball of dirt about 3 inches below the ground level and cover the top of the ball of dirt about 1 inch. Fill in gradually as the plant develops. In locations where there is danger of flooding, or poor drainage, do not plant as deep.

Cut all plants back to 2 or 3 pairs of leaves above the ground or at least pinch out the top to cause the plant to branc?.

Water thoroughly and then protect with open basket or open crate for a few days as a partial protection from the sun and wind. For cut worms, scatter Poison Bait the evening of planting. See "Cut Worms."

Dahliadel Green Plants are properly grown and hardened for shipment and in our specially designed shipping box have been successfully sent all over the U.S.

WHEN TO PLANT. One of the common errors in dahlia culture is planting too early. In the latitude of Philadelphia they should be planted between May 15th and June 15th. Farther north, where hot summers are less harmful and early frosts are prevalent, plant as soon as danger of frost is over.

Where seasons are still shorter in the north, start tubers or plants in cold frames in pots or in squares of inverted sod so they can be planted in your garden without disturbing the feed roots. This will give you two to three weeks longer growing season.

The further south you are and the earlier you plant the more you will have to cut back, thin out and disbud to get large blooms the end of the season.

DIVIDING CLUMPS. It requires a little judgment to divide dahlia roots properly, as some varieties are more compact than others. The eyes will be found around the stem or crown, and never on the tuber itself, like a potato. Hence a tuber without a piece of the crown is worthless. A division consisting of a good tuber with one good eye is all that is necessary; more are of no advantage. Large clumps should never be planted whole. 


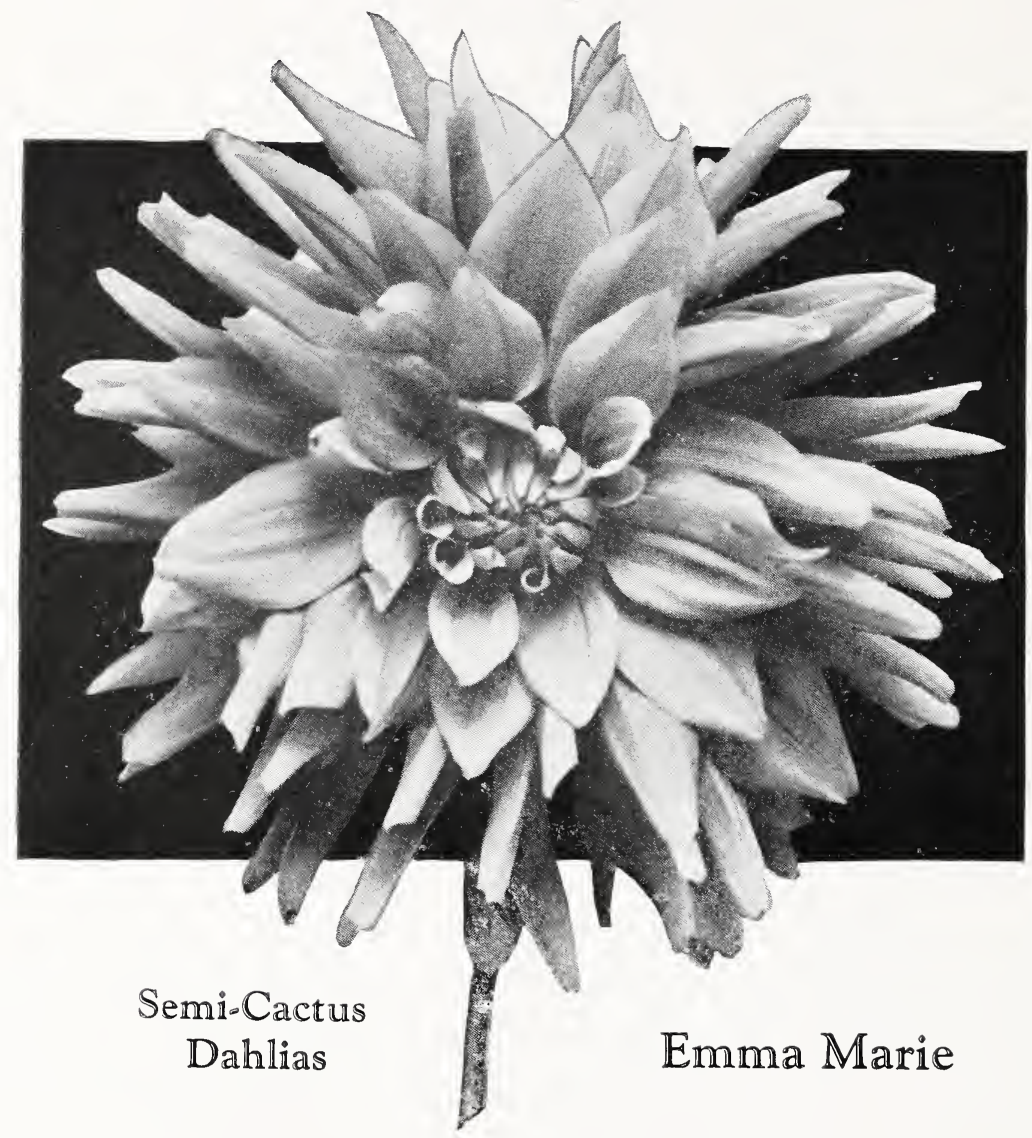

EMMA MARIE (Dahliadel 83), c $g$ e, Bloom $71 / 2 \times 3$, Bush $6 \mathrm{ft}$. A favorite because of its pleasing shade of clear pink with a creamy white centre and its combination of exhibition and commercial qualities. It is a robust grower, producing deep, full-centred blooms on three to four foot stems in ordinary field culture.

Tubers, $\$ 1.00$; Plants, .50

ELSIE DANIELS (M. \& S. 83), g e, Bloom $9 \times 4, B$ sh $41 / 2 f t$. The color of this wonderful dahlia is pale violet orchid with long, wavy white centre petals. Bushes grow well with immense exhibition blooms held well out of the foliage on strong stems.

FRANCIS LOBDELL (Waite 80), $\boldsymbol{g} \boldsymbol{e}$, Bloom $7 \times 5, \boldsymbol{B}$ s $\boldsymbol{h} 5 \mathrm{ft}$. Flowers large and of perfect form, mallow pink, shading to white in the centre. Wonderful free and early bloomer, splendid bedding variety as well as exhibition.

JEAN HARE (F. \& M. 80), g e, Bloom $9 \times 4 \frac{1}{2}$, Bush $4 \frac{1}{2} f t$. A very attractive autumn-shade dahlia on account of its size and beauty. Color, buff apricot, with the outer petals of a golden bronze. Stems upright and perfectly stiff. Bush rather compact, but a free bloomer.

Tubers, $\$ 5.00$; Plants, \$2.50

JERSEY'S SWEETHEART (Waite 82), c g, Bloom $7 \times 3 \frac{1}{2}$, Bush $31 \frac{1}{2} \mathrm{ft}$. A dainty, attractive variety for cutting. Delice pink, shading to white in the centre. Flowers produced in great quantities on slender, stiff stems.

Tubers, \$1.00; Plants, .50

SOLE MIO (Pelicano 78), g e, Bloom $9 \times 4$, Bush $31 / 2$ ft. A bright spot in your garden. Color, deep yellow suffused apricot. Flowers are of good substance and held well on excellent stems. Not thrip-proof. 


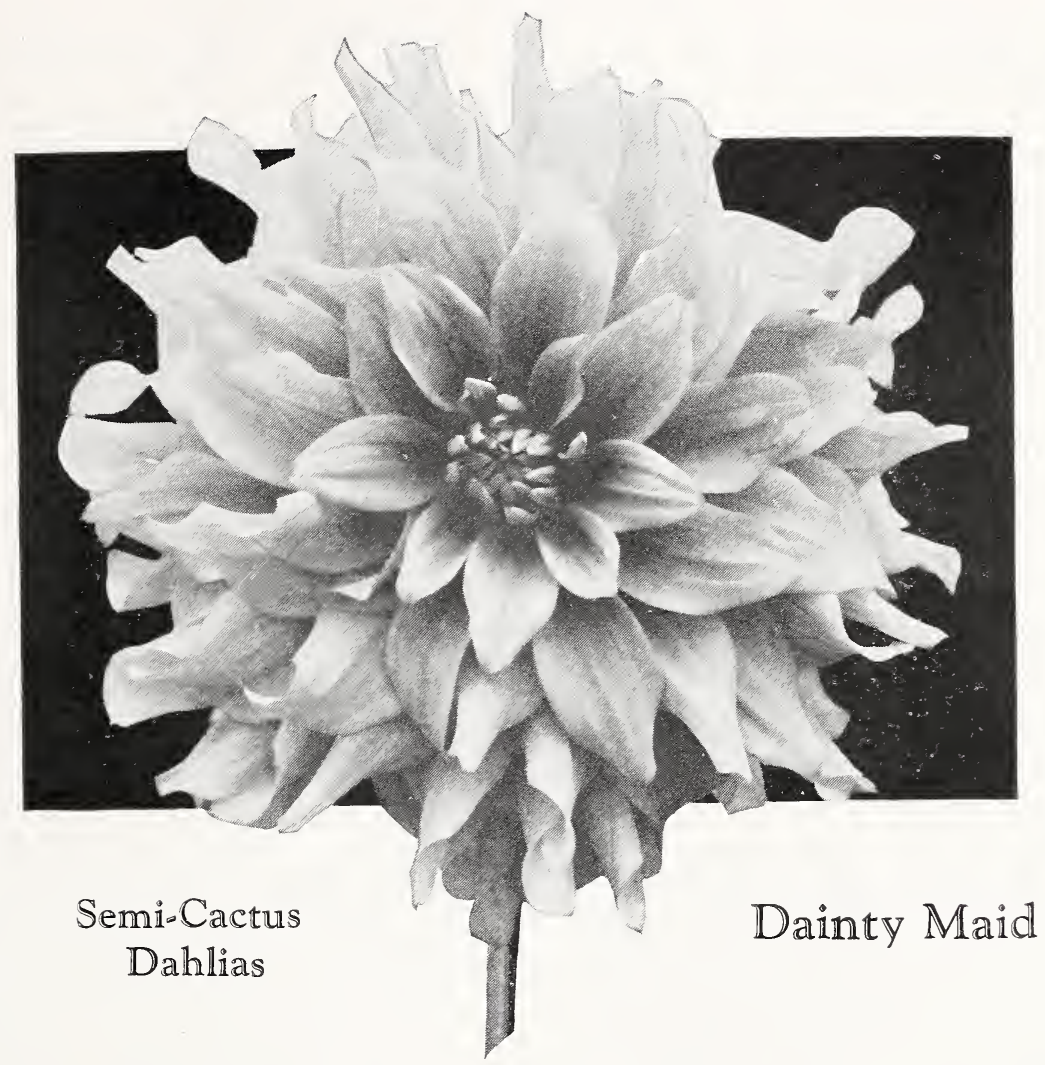

DAINTY MAID (Kemp 85), c $g$, Bloom $6 \times 4, B$ ush $51 / 2 f t$. This is the dahlia for those desiring beauty and grace, and not size. It is an early and profuse bloomer on upright bushes. Color, light sulphur yellow, a little deeper than Break O'Day. Blooms and stems are perfect. Its wonderful keeping qualities make it an ideal cut flower.

$\$ 1.00$

BREAK O'DAY (Dahliadel 76), g, Bloom $7 \times 4$, Bush 6 ft. A popular standard variety. The color is a delicate clear sulphur yellow, shading to sulphur white at tips, illuminated by a satiny sheen, giving the flower a waxy appearance. A. D. S. Cert. A strong grower and profuse bloomer.

CIGARETTE (Boston 81), c g, Bloom $7 \times 4$, Bush $61 / 2 f t$. Creamy white, heavily edged orange with color variations. Some flowers come all orange red. Petals are long and narrow, inclined to roll. Blooms large, of good substance on excellent stems. Good for cutting. .75

EAGLE ROCK BEAUTY (Broomall 84), $g$ e, Bloom $9 \times 31 / 2$, Bush 5 ft. This fine, impressive dahlia certainly is a pretty combination of pastel pink with ivory or creamy white centre. Petals long and gracefully twisted. A pleasing and satisfactory variety.

Tubers, \$3.50; Plants, $\$ 1.75$

\section{ALL THE ABOVE VARIETIES ARE THE SAME FORM AS ILLUSTRATION}

JERSEY GROWN DAHLIA SEED-Owing to advance orders and adverse growing conditions for the development of seed last season, we are unable to book any further orders for Jersey Grown Seed. 


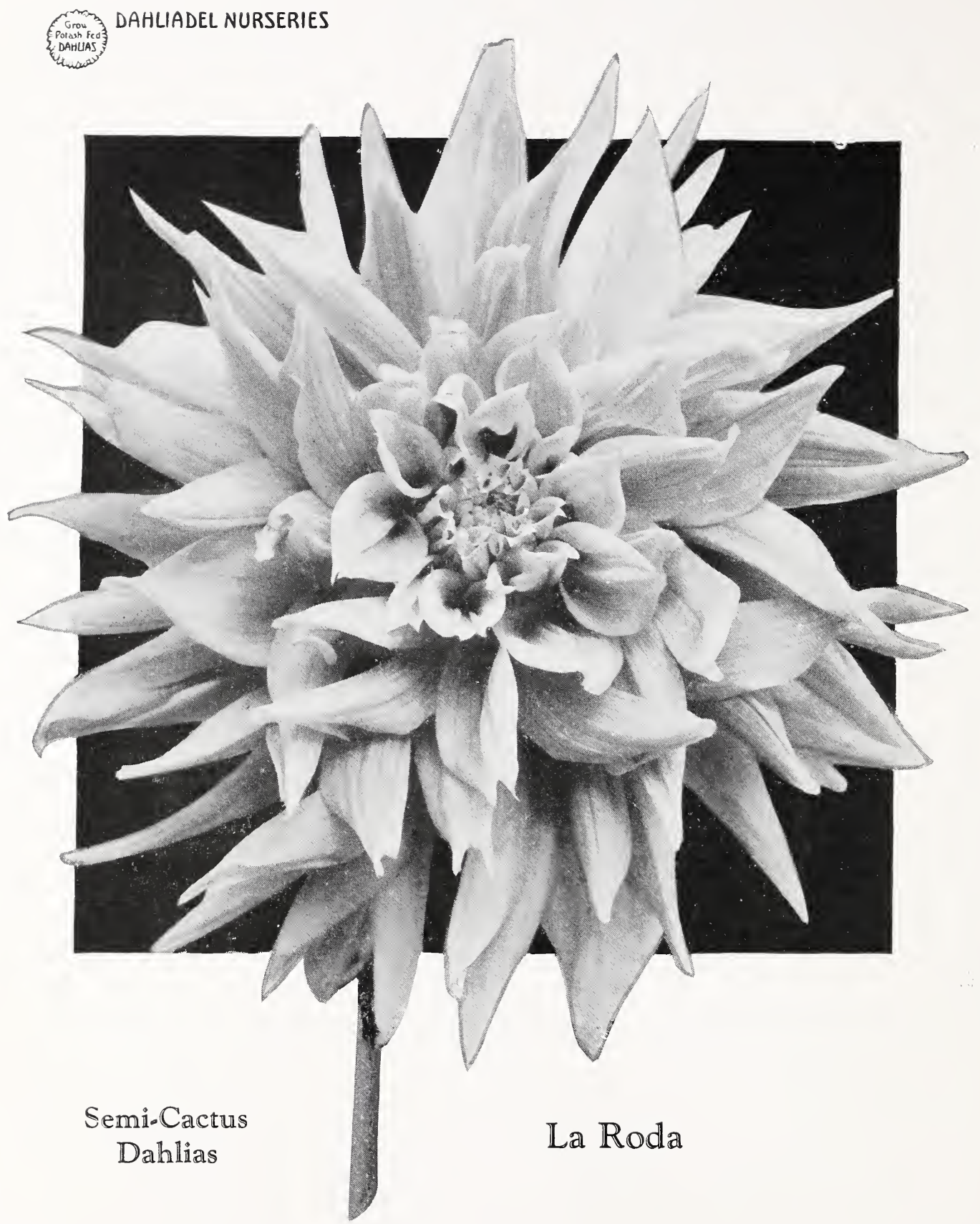

LA RODA (Broomall 89), c $g$ e, Bloom $10 \times 4$, Bush 5 ft. This beautiful new variety is an unusual silver rose pink with large, well-formed flowers held erect on strong stems. The formation is somewhat irregular, with numerous petals at the centre. Listed as a Hybrid Decorative by the originator, but a wonderful Hybrid Cactus for us. A good keeper for cutting. It is a shy tuber maker either from tubers or green plants.

Tubers, \$7.50; Plants, \$3.75 


\section{SEMI.CACTUS DAHLIAS-Continued}

CITY OF NEW YORK (Harding 86), 1929, $g$ e, Bloom $10 \times 5$, Bush 41/2 ft. A very attractive and distinctive dahlia. Color, pale golden amber at centre, softly overshaded light salmon passing to a rich salmon rose on the edges of the petals. This unusual coloring, along with its graceful form, good-keeping qualities, and growing habits make it very desirable. Plants, $\$ 5.00$

LA MEXICANA (F. \& M. 85), 1928, g e, Bloom $8 \times 4$, Bush 41/2 ft. This dahlia will appeal to those who liked the color of The U. S. A. Its form is very similar to illustration, while its color is a blending of burnt orange and copper tinged with gold. Blooms freely on slender, stiff stems.

Tubers, \$2.50; Plants, \$1.25

META SCAMMEL (Andrews 82), 1929, g e, Blooms $9 \times 41 / 2, B$ sh $5 \mathrm{ft}$. Centre pale amaranth pink shading to deep amaranth pink. Artistic because of its irregularly placed petals and pointed tips, which curl and twist, giving depth to the flower. Held high above dark green foliage on long, slender stems. Good growing habits.

Tubers, \$5.00; Plants, $\$ 2.50$

MINNIE EASTMAN (Eastman), $c g$ e, Bloom $8 \times 4, B u s h 6 f t$. This fine introduction has been a popular winner at both the Baltimore and Maryland Dahlia Society Shows for the past three years. It is a very pretty hybrid cactus of a bright flame color with undershadings of deep yellow. Stems, long and erect. Bush growth healthy, with smooth, glossy foliage.

Tubers, \$7.50; Plants, \$3.75

MY MARYLAND (Downs 83), c $g$ e, Bloom $8 \times 4, B u s h 5 f t$. This graceful, broad-petaled dahlia is a rich bright pink, each petal tipped with ivory. Flowers are large on strong stems. This dahlia reminds one of a glorified Attraction with more pink in its make-up, larger and with a better centre. A. D. S. Cert.

Tubers, $\$ 7.50$; Plants, $\$ 3.75$

ALL THE ABOVE VARIETIES ARE THE SAME FORM AS ILLUSTRATION

\section{FERTILIZERS}

Of the ten elements considered absolutely necessary to plant growth, we find nitrogen, phos. phorus and potassium the prime essentials and the ones most lacking.

Nitrogen stimulates the growth above ground, producing large bushes and flowers, but if used to excess the flowers will be soft, wilting readily, and the bushes will be overgrown and lower the vitality of the tubers.

Phosphoric acid increases the root development, especially the lateral and fibrous roots, strengthens the plant growth and gives substance to the bush and flowers. It also aids in ripening the tubers. This element is found in bone meal, with a small amount available in manures.

Potash is the balancing agent for nitrogen and phosphoric acid. It gives color to the flowers and foliage, and vigor and tone to the plant in general. It is an essential in starch formation and aids in the maturing of well-nourished tubers.

FERTILIZER to be applied before planting.

Scatter broadcast after spading and mix thoroughly into the top soil to every 100 square feet of ground or to each 10 dahlia hills.

5 lbs. Raw Bone Meal

10 lbs. Unleached Wood Ashes or

$1 \mathrm{lb}$. Muriate or Sulphate of

Potash, not both

Bone meal may be doubled if soil is very poor.

\author{
FERTILIZER or TOP DRESSING to be \\ applied about August 15. \\ Scatter broadcast over ground not closer \\ than 6 inches nor more than 18 inches \\ from the stalk and rake in, to every 10 \\ hills. \\ 11/2 lbs. Raw Bone Flour \\ $11 / 2$ lbs. Animal Tankage or \\ 4 lbs. Sheep Manure, not both \\ 5 lbs. Unleached Wood Ashes or \\ $1 / 2$ lb. Muriate or Sulphate of
}

Potash, not both

HOW TO PLANT. Tubers should be planted in trenches or holes 6 inches deep, laid flat down (not on end) and covered with earth not over 2 inches in depth, filling in as the plant develops. Where drainage is poor, do not plant so deep and keep a furrow open between rows to facilitate drainage in wet weather.

Do not plant the roots in or over any quantity of compost or hot manure. The rows should be from 4 to 5 feet apart and the plants in the row from 2 to 3 feet apart, or from 6 to 10 square feet should be allowed for each plant. A novel way to plant is to place your stakes $4 \times 5$ feet apart, and plant a tuber or plant on each side of the stake, giving you room to walk between and care for your plants, and also get as many in a given area as if planted twice as close. Different varieties will not mix by growing them together. Also, should one plant fail, there will be no blank places. 


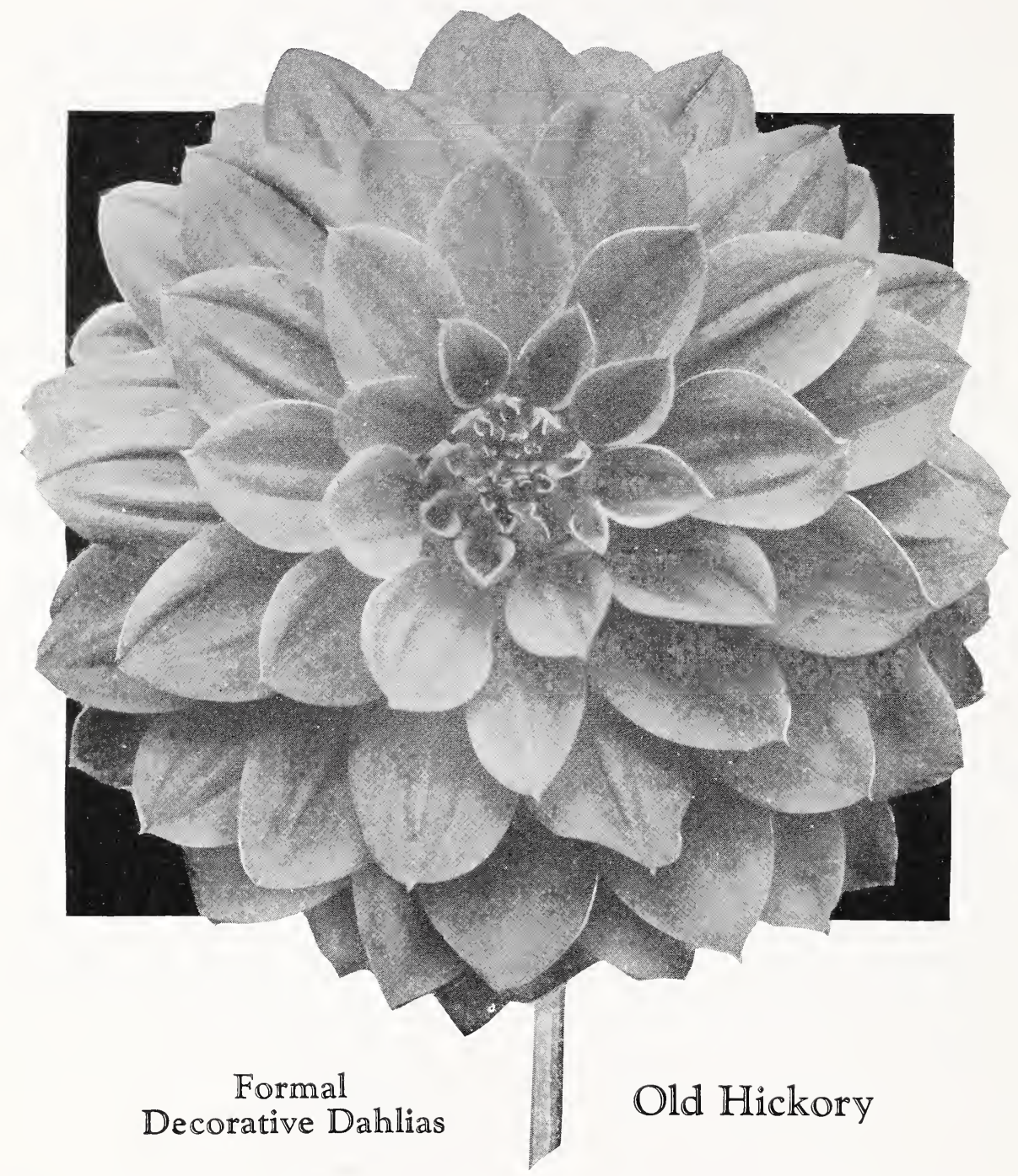

OLD HICKORY (Dahliadel 85), $\boldsymbol{c} g$ e, Bloom $7 \times 5$, Bush $31 / 2 f t$. The dahlia that is easy to grow. A rough-and-ready, rugged plant, semi-dwarf with each branch bearing a large bloom which is almost a ball with centers always full. Stems are ideal for basket arrangement, and the blooms are wonderful keepers. Color, madder red with apricot suffusions.

Tubers, $\$ 5.00$; Plants, $\$ 2.50$

AMUN RA (Seal 79), g, Bloom $9 \times 3$, Bush 6 ft. Described as resembling a setting sun. Outer petals are a gorgeous shade of copper and orange, shading to gold and amber and deepening in the center to a reddish bronze. Some flowers show green at centre.

BARBARA REDFERN (Redfern 80), g e, Bloom $10 \times 4 \frac{1}{2}$, Bush $51 / 2 \mathrm{ft}$. This dahlia is a beautiful combination of old rose and gold. Petals are long, with a slight twist, showing both colors. Deep flowers are held on long stems. A continuous bloomer and healthy grower.

Tubers, \$3.50; Plants, \$1.75 


\section{FORMAL DECORATIVE DAHLIAS-Continued}

CHEMAR'S EUREKA (Chemar 88), 1929, c $g$ e, Blooms $8 \times 3$, Bush $6 \mathrm{ft}$. A dahlia that is decidedly outstanding. The average blooms are 95 per cent white, with a touch of lavender pink disappearing as the flower becomes fully open. A strong, healthy grower with long, stiff stems. One of the best whites on the market today.

Tubers, $\$ 10.00$; Plants, $\$ 5.00$

ELITE GLORY (Kennedy 85), g e, Bloom $10 \times 4$, Bush $41 / 2 \mathrm{ft}$. Sensational rich red decorative, which is usually found on the exhibition table. Blooms are unquestionably massive with good substance on strong stems.

Tubers, \$2.50; Plants, $\$ 1.25$

FAITH GARIBALDI (Boston 85), $g$ e, Bloom $9 \times 3, B u s h 5 f t$. This large exhibition dahlia is deep rose, shading lighter on outer petals held on good stems. A strong grower and free bloomer.

$\$ 1.00$

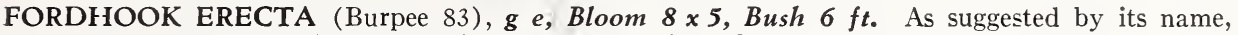
stems are strong and erect. Bright amaranth pink blossoms, shading lighter at the base of petals, produced freely on ideal bush.

Tubers, $\$ 2.00 ;$ Plants, $\$ 1.00$

FORDHOOK MARVEL (Burpee 80), 1929, $g$ e, Bloom $8 \times 4$, Bush $51 / 2$ ft. Lovely salmon shading to reddish copper. This dahlia is a strong, healthy grower with large, heavy foliage.

Tubers, \$7.50; Plants, \$3.75

F. T. D. (F. \& M. 83), c g e, Bloom $7 \times 4$, Bush 6 ft. A sport of Trentonian and an exact counterpart of its parent except in color, which is a rich Tyrian rose. This variety was named for the Florists' Telegraph Delivery. Flowers are held well above the foliage on rigid stems. A prize winner. Reacts good on severe pruning. D. S. of N. J. Cert.

Tubers, \$2.00; Plants, $\$ 1.00$

JUDGE LEON McCORD (Boston), 1929, $g$ e. An enormous, regular-formed dahlia of the deepest shade of gold, with a reverse of old gold. Stems are upright, long and stiff, holding blooms well above foliage. It keeps well on the bush or when cut. Profuse bloomer.

Plants, $\$ 7.50$

MARDI GRAS (Diggle 80), 1929, $g$ e, Bloom $9 \times 4, B u s h ~ 7 f t$. A bold flower of the American Beauty shade. Blooms are held on long stems well above the foliage. Bush tall and rugged and stands good culture.

Tubers, \$7.50; Plants, $\$ 3.75$

MARGARET MASSON (F. \& M. 83), $g$ e, Bloom $8 \times 31 \frac{1}{2}$, Bush $41 / 2 \mathrm{ft}$. Wonderful exhibition variety of a beautiful silvery pink of regular form. It is an excellent keeper, and flowers are produced abundantly on stiff stems.

$\$ 1.00$

MR. C. H. DRESSELHUYS (Sluis \& Groot 79), c g, Bloom $6 \times 21 / 2, B u s h ~ f t$. Popular with the commercial grower because of its productiveness and keeping qualities. Medium-sized blooms on long stems. Similar to Delice in color. Soft rose pink, shading lighter.

.35

PINK FLAMINGO (Flamingo 74), c g, Bloom $6 \times 3, B$ sh $41 / 2 \mathrm{ft}$. One of our best keepers as a cut flower. An occasional open-centre flower does not taboo the variety as a profitable commercial flower. Color, violet rose, overlaid soft Tyrian rose.

.25

SALBACH'S WHITE (Salbach 85), c $g$ e, Bloom $8 \times 3, B u s h 6 f t$. We have in this variety an ivory white dahlia of good substance and keeping qualities, borne profusely on long, stiff stems, making it ideal for all uses. Bushes are healthy.

Tubers, $\$ 2.00 ;$ Plants, $\$ 1.00$

SALEM PRIDE (Sickler 83), 1929, g e, Bloom $10 \times 5$, Bush $4 \mathrm{f}$. A rather spectacular dahlia. Color, reddish violet suffused, streaked and lightly tipped white. Blooms are large and deep on good stems when disbudded. Bush rather compact and of nice growth for the front of your garden.

Plants, \$3.75

SENATOR BAIRD (Peacock 76), g, Bloom $8 \times 31 / 2, B u s h 5 f t$. One of the strongest and best growing rich deep red dahlias. Large, full-centred flowers are held on strong stems. .75

THE WORLD (Dahliadel 90), 1929, c ge, Bloom $9 \times 41 / 2$, Bush 5 ft. This wonderful new dahlia was selected at the A. D. S. Show in New York to bear the name of the New York World. The coloring is an unusually rich, deep, rosy magenta overlaid garnet with silver shadings on edges of petals. A rich and beautiful combination of colors. Perfect, full centres. Stems are strong and erect. Foliage leathery and repellent to insect injury. A good, sturdy grower and a real prize winner that has gone far ahead of expectations all over the country. This dahlia has more substance than any other dahlia we have. Tubers, $\$ 7.50$; Plants, $\$ 3.75$

TRENTONIAN (F. \& M. 81), ge, Bloom $7 \times 31 / 2, B u s h 6 f t$. A blending of old gold, amber and coppery bronze, with a centre zone of reddish bronze. Petals are well placed, making a flower of good lasting qualities. D. S. of N. J. Cert. 


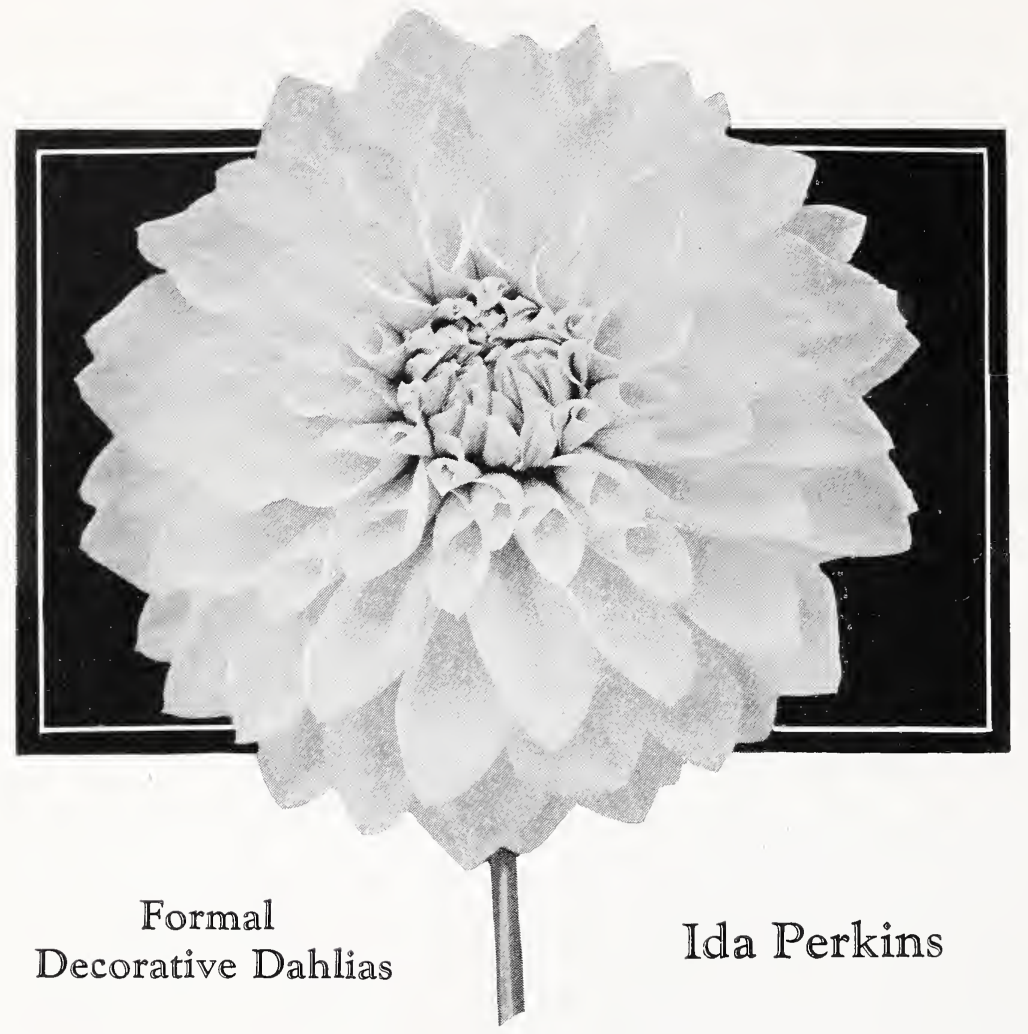

IDA PERKINS (Montrose 88), $g$ e, Bloom $8 \times 4$, Bush $51 / 2 f t$. One of the finest large white dahlias grown, of fine form and full centres, on strong and erect stems. Blooms early and continuous. Dark, leathery foliage. A coming prize winner. Tubers, $\$ 5.00$; Plants, $\$ 2.50$

D. M. MOORE (Wilmore 77), g, Bloom $6 \times 3 \frac{1}{2}$, Bush $4 \mathrm{ft}$. Rich dark velvety maroon, almost black. A most popular dark dahlia. Bush of medium height. Early and profuse.

ELSIE JANE (Schmidt 82), g, Bloom $8 \times 4$, Bush $6 \mathrm{ft}$. Flowers are of good size with full centres. It is a healthy, vigorous grower and prolific bloomer. Color, pale lilac rose, shading to white at the center and distinctly tipped with bright violet mauve. A beautiful flower. Stems at times are a little weak.

Tubers, $\$ 1.50$; Plants, .75

GLORY OF ARGONNE (Dahliadel 79), g, Bloom 61/2 $\times 3 \frac{1}{2}$, Bush 41/2 ft. Color, delicate violet rose, shading to white at centre. Perfect, even form, on erect stems.

JEAN KERR (Burpee 79), c g, Bloom $5 \times 3$, Bush $4 \mathrm{ft}$. This white dahlia of medium size is always in bloom. Bush compact. Flowers well above the foliage on good stems. Fine for bedding and a good keeper for cutting.

PEACOCK (Peacock 80), g, Bloom $6 \times 4$, Bush $31 / 2 f t$. One of the finest variegated dark red and white dahlias grown. Flowers borne erect, well above the foliage, of even form with full, deep centres, evenly marked as much white as reddish purple, a characteristic uncommon in variegated dahlias.

$\$ 1.50$

SHELIKOFF (Tyler 78), g, Bloom $61 / 2 \times 4$, Bush $5 \mathrm{ft}$. One of the best dark dahlias for your garden. Large, well-formed flowers of good substance on erect stems. Color, deep garnet.
A. D. S. Cert. 
SOIL PREPARATION AND CONDITIONING. The dahlia will grow and produce excellent results in a wide range of soils. It is not as much a matter of soil type as it is conditioning. To grow exhibition blooms to perfection, the nearer soil can be to ideal the better your results will be. Soil should contain enough clay to keep the fertility from leaching and also enough sand or stones to facilitate drainage. The primary factor, however, in growing dahlias is that of drainage, which in sandy soils is well taken care of, but in heavy soils dig in and thoroughly mix a quantity of coarse coal ashes into the subsoil.

We might suggest ditching 18 or more inches deep where the row is to be planted, running the ditch with the slope if possible. Fill in with coarse ashes, clinkers or any coarse material that will not rot, keeping it below spading depth, then fill in top with a mixture of soil and peat moss, probably 15 per cent to 20 per cent peat moss. This, although quite a task, will enable you to grow what your neighbors cannot, unless they do likewise.

The use of peat moss broadcast and mixed well into the top soil is an advantage on heavy soil to open it up and on light soil it will conserve moisture and hold fertilizer.

As soon as the soil can be worked in the spring it may be further improved by a cover crop of oats and Canada field peas. Or, better still, sow rye in September or October. Tha green crop will do no harm during the late blooming season, will winter over, and should be turned under about two weeks before planting. This will add organic matter, supplying humus and further adjusting soil conditions. If soil is poor, the oats or rye may be top dressed with stable or hen manure, the sooner after planting the better.

IRRIGATION. When your dahlias need water, wet the ground so it will penetrate about a foot deep when growing in light soil. In heavy soil, watering need not be as heavy, as it may be followed by a rain and overwatering may result. Cultivate as soon as sufficient drainage has taken place, and do not water again until necessary, which will be a week or more.

Do not spray your dahlia bushes, and sprinkle the surface of the ground every night or so, for this will only pack the surface, preventing air circulation and causing the soil to crust and dry rapidly in the sunshine. This also draws the feed roots to the surface, to be sickened by the heat of the sun's rays. The flowers obtained are soft and the root development very poor, low in vitality and hard to winter.

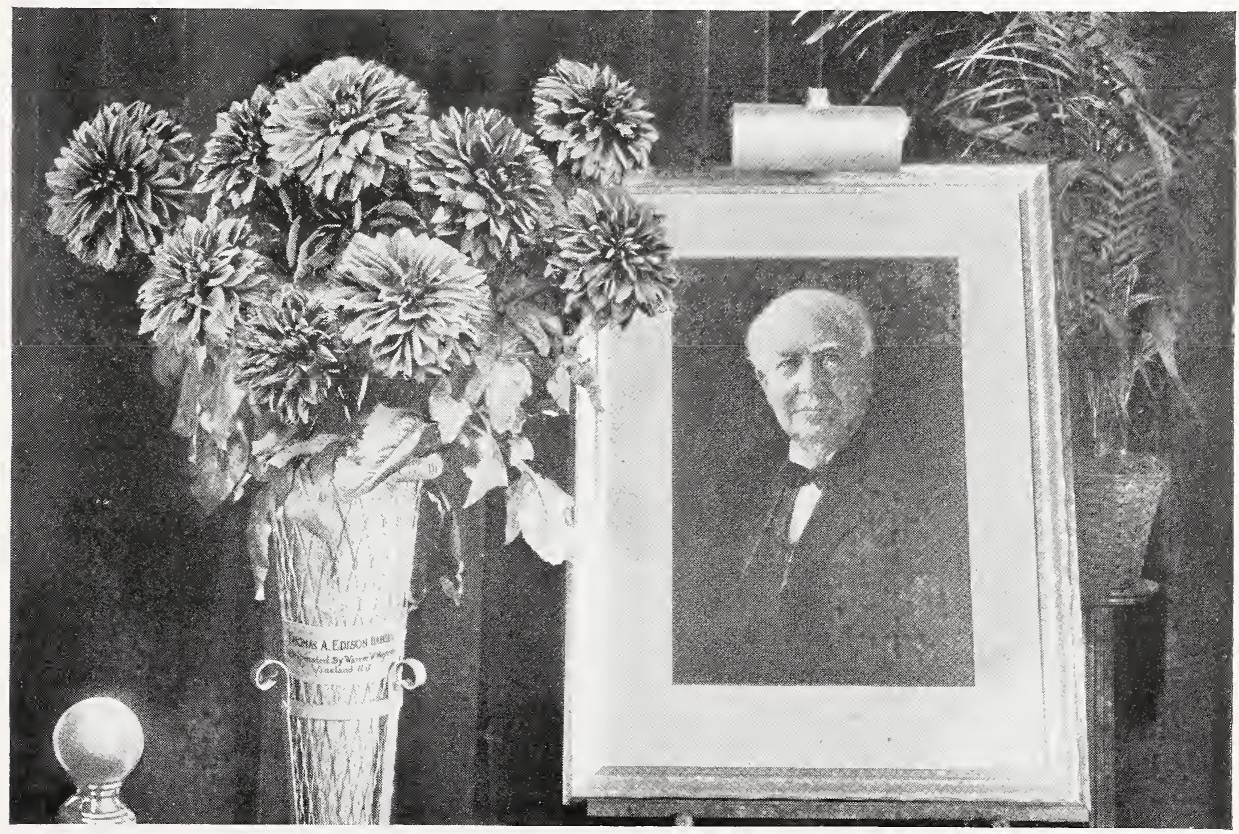

DISPLAY AT THE NEW YORK EXPOSITION-THE FIRST ELECTRIC BULB-THE DAHLIA NAMED IN HIS HONOR-AND AN OIL PAINTING OF MR. EDISON 


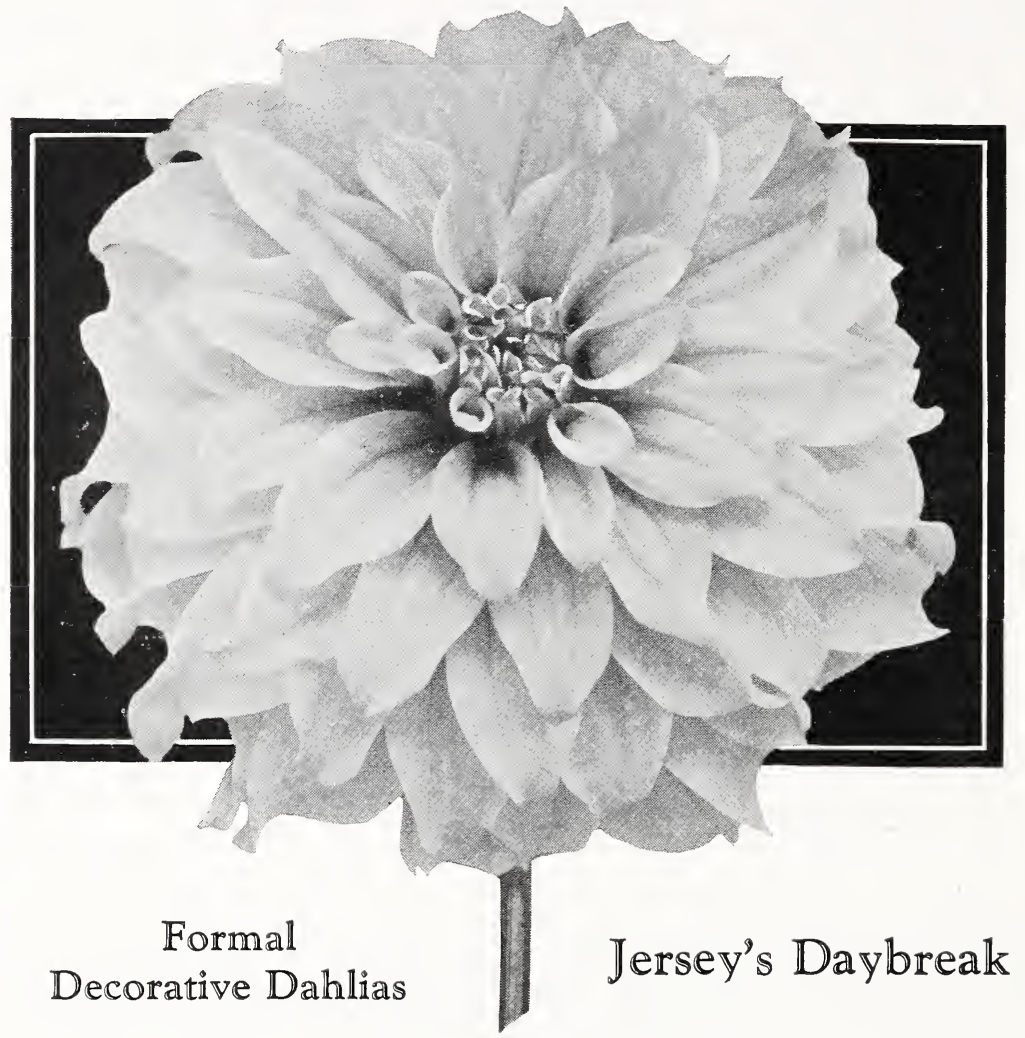

JERSEY'S DAYBREAK (Waite 84), $g$ e, Bloom $8 \times 4$, Bush $6 \mathrm{ft}$. This much-admired dahlia is Hermosa pink, shading to creamy yellow in the centre. Flowers of good size with high pointed centres; hold their splendid form throughout the season. The stems are rigid and the foliage is of a leathery texture.

Tubers, $\$ 3.00 ;$ Plants, $\$ 1.50$

GRACE (Bibbs 87), 1929, c g e, Bloom $6 \times 2 \frac{1 / 2}{2}$, Bush $6 \mathrm{ft}$. This dahlia will remind you a lot of Jersey's Beauty in form, not quite as deep a flower, but will give you twice as many blooms. It might be called a blooming fool, from early to late with centres perfectly full, stems long and stiff, but not clumsy. Color, pure white tipped and suffused lavender. As a cut flower it is going to be a money-maker.

Tubers, \$7.50; Plants, \$3.75

IVORY (Boston 86), 1929, g e, Bloom 91/2 x 5, Bush $5 \mathrm{ft}$. Beautifully formed dahlia with long, pointed, wavy petals. Deep cream at base of petals and a shade lighter at outer edges, except for a tiny tip of deep cream. Color does not vary during season and centres are always full. Blooms profusely on stiff stems.

Plants, $\$ 7.50$

HALVELLA (McWhirter 79), $g$ e, Bloom $8 \times 4$, Bush $61 \frac{1}{2} f t$. A massive dahlia on long stems. Flowers are a beautiful shade of rose pink, a little darker than Jersey's Beauty. Profuse early bloomer.

JERSEY'S BEAUTY (Waite 89), c g e, Bloom $6 \times 4$, Bush $61 / 2 \mathrm{ft}$. Probably the most popular of any dahlia especially as a cut flower. The ideal pink for exhibition or florist use. Large, deep flowers of perfect form on long stems. Free, early bloomer with exceptional keeping qualities.

Tubers, .75; Plants, .50

JERSEY'S GEM (Waite 84), c $g$ e, Bloom $8 \times 3$, Bush 6 ft. Large, well-formed flowers of lavender pink on long, erect stems. A good grower and bloomer. A. D. S. Cert. 


\section{FORMAL DECORATIVE DAHLIAS-Continued}

KENTUCKY (Castlewood 87), 1929, c g e, Bloom $7 \times 5$, Bush $6 \mathrm{ft}$. This dahlia has the same ideal characteristics as Jersey's Beauty, of which it is a sport, and apparently a stronger grower. Its color is the Jersey Beauty's pink, with a lot of yellow and gold blended in, making it more of a salmon pink. Good for cutting.

Tubers, \$10.00; Plants, \$5.00

M. H. DE YOUNG (Boston 86), c $g$ e, Bloom $7 \times 3, B$ sh 5 ft. Pure gold with the centre illuminated with a brighter shade. Large blooms are held high on stiff stems well above the foliage. An excellent autumn shade cut flower or exhibition variety.

Tubers, $\$ 1.50$; Plants, $\$ 1.00$

MISS SAN FRANCISCO (Pelicano 83), c $g$ e, Bloom $8 \times 5$, Bush $41 / 2 f t$. One of the best Western introductions for 1928. True orchid shade suffused with deep rose. Flowers of good form and substance held well above the foliage on strong, erect stems, centres full. A sturdy grower with heavy foliage.

Tubers, \$2.50; Plants, $\$ 1.25$

MRS. CARL SALBACH (Salbach 78), $g$ e, Bloom $71 / 2 x 3$, Bush $7 \mathrm{ft}$. Although not as deep as Jersey's Beauty, this dahlia is very similar in petal formation, stem and keeping qualities, all of which are ideal. Color, lilac rose, shading to white at base of petals, giving it a general tone of soft rose.

PRES. WILSON (Jones 84), g, Bloom $7 \frac{1}{2} \times 3 \frac{1}{2}$, Bush $4 \frac{1}{2} \mathrm{ft}$. One of the most striking variegated dahlias. Crimson carmine tipped white; a few flowers all red. Bush dwarf; flowers numerous on good stems. Its one fault-a poor root maker. Tubers, $\$ 1.50 ;$ Plants, $\$ 1.00$

PRIDE OF CALIFORNIA (Lohrman 78), c g, Bloom $6 \times 3 \frac{1}{2}$, Bush $51 / 2 \mathrm{ft}$. A large crimson red shading darker at the center, which is very full; petals notched. Profuse bloomer on good stems.

PRIDE OF SAN FRANCISCO (McWhirter 78), c $g$, Bloom 71/2 $x$ 4, Bush 4 ft. Another bedding variety when grown naturally, but nice stems can be produced by disbudding. A beautiful combination of salmon pink, suffused soft rose, shading to gold at base of petals. .75

ROBERT SCOTT (Brock 80), $g$ e, Bloom $8 \times 3 \frac{1}{2}$, Bush $5 \mathrm{ft}$. This fine new dahlia is of a bright apricot yellow with shades of rose. Flowers are large and deep, of good form, on excellent stems. The bush is of stocky growth.

Tubers, $\$ 1.50 ;$ Plants, $\$ 1.00$

SAGAMORE (Kirby 84), c $g$ e, Bloom $7 \times 3 \frac{1}{2}$, Bush $51 / 2 f t$. This dahlia is a wonderful commercial and exhibition variety. Color, amber gold, elusively shaded with a warm salmon rose and orange buff. An open, strong grower with good stems, of uniform large size.

Tubers, \$1.00; Plants, .50

SANHICAN'S PRINCESS (F. \& M. 83), c g, Bloom $61 / 2 \times 31 / 2$, Bush $51 / 2 f t$. This fine dahlia is for those of artistic temperament, beauty rather than size, specially suited for cutting and indoor decorating. Color, true shrimp pink. An early and profuse bloomer on stiff stems. D. S. of N. J. Cert.

$\$ 1.00$

WATCHUNG SUNRISE (Smith 86), $g$ e, Bloom $9 \times 5$, Bush 6 ft. This fine variety differs from the accompanying illustration, as the petals are longer and somewhat curled or twisted. In color it is a golden amber, with the reverse of petals showing rose pink and each petal distinctly edged rose pink, making it very distinctive. Flowers are massive on strong, erect stems.

Tubers, $\$ 5.00$; Plants, $\$ 2.50$

WHITE GLORY (Alling 80), c g, Bloom $8 \times 3 \frac{1}{2}$, Bush $4 \mathrm{ft}$. This fine, large white is an early and continuous bloomer. Flowers well formed, full centred on long, erect stems. A. D. S. Cert.

$\$ 1.00$

ALl THE ABOVE VARIETIES ARE THE SAME FORM AS ILLUSTRATION

CULTIVATION. By cultivating at least once a week, and as soon after a rain as the ground can be worked, the weeds will be held in check and a soil mulch formed which will conserve the moisture and lessen the need of irrigation.

As the piant aevelops and the feed roots come toward the surface, the ground should be worked rather shallow around the hill for the radius of at least a foot. Still work the balance of the ground rather deep and bring some fresh soil to the plant at each cultivation, giving the plant a new supply of food and protecting the surface roots from the heat of the sun. Have the hills mounted 5 or more inches by the middle of September. This will help support the stalks. 


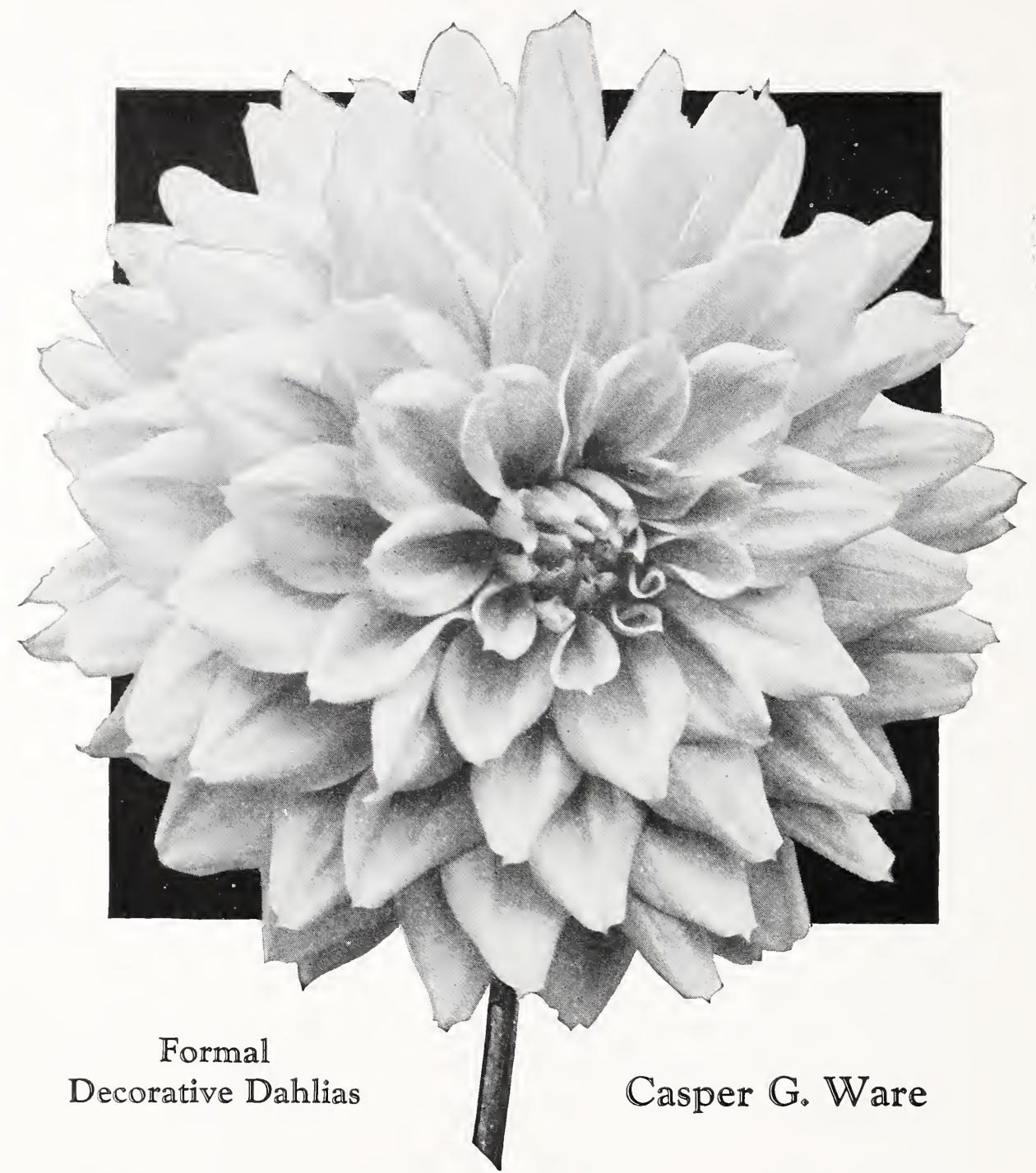

CASPER G. WARE (Bowen-Dahliadel 85), c $g$ e, Bloom $8 \times 4, B$ sh 4 ft. This is truly a dahlia of many uses. When grown naturally without disbudding, you have an ideal flower for bedding or hedge effect with a mass of blooms throughout the season. For exhibition or cut flowers, prune out, leaving only four to eight shoots, and by disbudding you will have blooms up to 10 inches in diameter with full centres until frost. It is one of the best and outstanding varieties, especially for its keeping qualities. Color, a pleasing shade of bright silvery violet rose. D. S. of N. J. Cert.

Tubers, \$1.50; Plants, .75

A. H. S. '23 (Peacock 79), g e, Bloom $8 \times 4, B$ sh 41/2 ft. A very attractive and well-formed deep sulphur yellow dahlia with rather short stems, but good when disbudded. Bush growth, stocky and healthy.

Tubers, \$2.00; Plants, \$1.00

DR. JOHN CARMAN (Dixon 88), 1929, g e, Blooms $11 \times 5$, Bush $5 \mathrm{ft}$. A dahlia you will have to admire, as it is large and attractive, but not coarse. Color, Tyrian rose, tipped silver, similar to Robert Treat, and greatly improved if grown in partial shade, as this softens the coloring. Its score denotes a dahlia of exceptional growing and blooming qualities and general habits.

Tubers, $\$ 7.50$; Plants, $\$ 3.75$ 


\section{FORMAL DECORATIVE DAHLIAS-Continued}

ELLINOR VANDERVEER (Seal 81), $g$ e, Bloom $8 \times 4$, Bush $51 / 2 f t$. A universal favorite of great size, depth and substance, on excellent stems. Glowing rose-pink with darker shadings

FORT WASHINGTON (Rindfleisch-Jost 85), $\mathrm{g}$ e, Bloom $10 \times 4, \boldsymbol{B}$ ush $7 \mathrm{ft}$. This is at present the best and largest dark red exhibition decorative. The bushes as well as the flowers are giants with long, strong stems. A dark mahogany red which does not fade.

Tubers, \$2.00; Plants, $\$ 1.00$

JERSEY'S GLORY (Waite 80), 1929, $g$ e, Bloom $8 \times 4$, Bush 5 ft. These large, well-formed dahlias are well placed on long and stiff stems, which sometimes arch gracefully. Color a yellow hue or orange, shaded orange buff and copper orange. Robust grower with thick, leathery leaves, producing very freely. Tubers, \$7.50; Plants, \$3.75

MARCELLA (Gill 76), $\boldsymbol{c} g$, Bloom $5 \times 2$, Bush $5 \mathrm{ft}$. A delightful clear, soft pink of perfect form, held erect on individual stems. Exceptionally free bloomer of medium size which is fine for cutting. Scores well as a cut flower.

MONMOUTH JEWEL (Kemp 83), $g$ e, Bloom $8 \times 3$, Bush $61 / 2 f t$. A seedling of Amun Ra. Color, bitter-sweet orange, shading lemon chrome at base of petals. Large, well-formed flowers held well above the foliage on strong, stiff stems. Plants are strong and healthy growers resistant to leaf-hoppers.

Tubers, $\$ 3.50$; Plants, $\$ 1.75$

MR. CROWLEY (Broomall 77), g, Bloom 61/2 $x 3$, Bush $41 / 2 \mathrm{ft}$. A bright colored garden dahlia of glowing salmon pink with base of petals yellow. Although a compact grower, good stems can be produced by disbudding. Fine for color effect when grown naturally.

.75

MRS. I. DE VER WARNER (Marean 84), c g e, Bloom $10 \times 3$, Bush $6 \mathrm{ft}$. No dahlia planting should be without this universal favorite. Color, a clear, bright lilac rose. The plant is a strong open grower, and the giant flowers can be produced on stems up to 5 feet in length by pruning and disbudding.

SANHICAN'S QUEEN (F. \& M. 85), 1929, c g e, Bloom $8 \times 4, B$ sh 41/2 ft. Most unusual coloring. A blending of apricot with a faint blush of carmine rose deepening toward the tight centres, which are always full. Attractive blooms are held high above dark green foliage on straight, stiff stems. Good growing habits and good keeper.

Tubers, $\$ 5.00 ;$ Plants, $\$ 2.50$

SNOWDRIFT (Broomall 75), g, Bloom $9 \times 3, B u s h 4 \frac{1}{2} f t$. Large pure white with broad, rather flat waxy petals. Has a good stem by disbudding. A good bloomer and easy to grow.

SPOTSWOOD BEAUTY (Rigler 85), c $g$ e, Bloom $8 \times 4$, Bush 5 ft. A beautiful, soft combination of Chatenay pink with yellow shadings at the base of petals. Flowers are of good form on long, erect stems well above the foliage. Plants are strong, healthy growers of good branching habits.

Tubers, $\$ 5.00$; Plants, $\$ 2.50$

TREASURE ISLAND (Dahliadel 88), 1929, c g e, Bloom $9 \times 5$, Bush $6 \mathrm{ft}$. One of the brightest autumn shade dahlias we have seen. Color, bright apricot with gold, and rose suffusion and shadings. Bush growth is strong, branches readily from the ground, giving 5-foot stems. Flowers are held erect, with full centres throughout the season. Won in 25 Bloom Basket Class in Trenton. Also won in 9 Bloom Decorative and 25 Bloom Basket at Camden. A dahlia that will score high both early and late in season. See color illustration on back cover of this catalog.

Tubers, \$7.50; Plants, \$3.75

UNCLE TOM (Reed-Adams 83), g e, Bloom $71 / 2 \times 3$, Bush $51 / 2 f t$. This is one of our best deep garnets, almost black, yet rich and artistic. Flowers are good keepers, held erect on strong stems. A color needed in your collection.

Tubers, \$1.50; Plants, .75

YELLOW BEAUTY (Wood), 1929, c g e, Bloom $7 \times 4$, Bush 6 ft. A yellow dahlia resembling Jersey's Beauty, with similar characteristics of growth. Good commercial and exhibition dahlias with slender but stiff stems, always holding flowers erect. Tubers, $\$ 10.00 ;$ Plants, $\$ 5.00$

\section{ALL THE ABOVE VARIETIES ARE THE SAME FORM AS ILLUSTRATION}

Don't use nitrate of soda as a fertilizer. Don't try to grow exhibition blooms by forcing the life out of your stock with sheep or any other manure, without balancing your plani food with phosphoric acid and potash. 


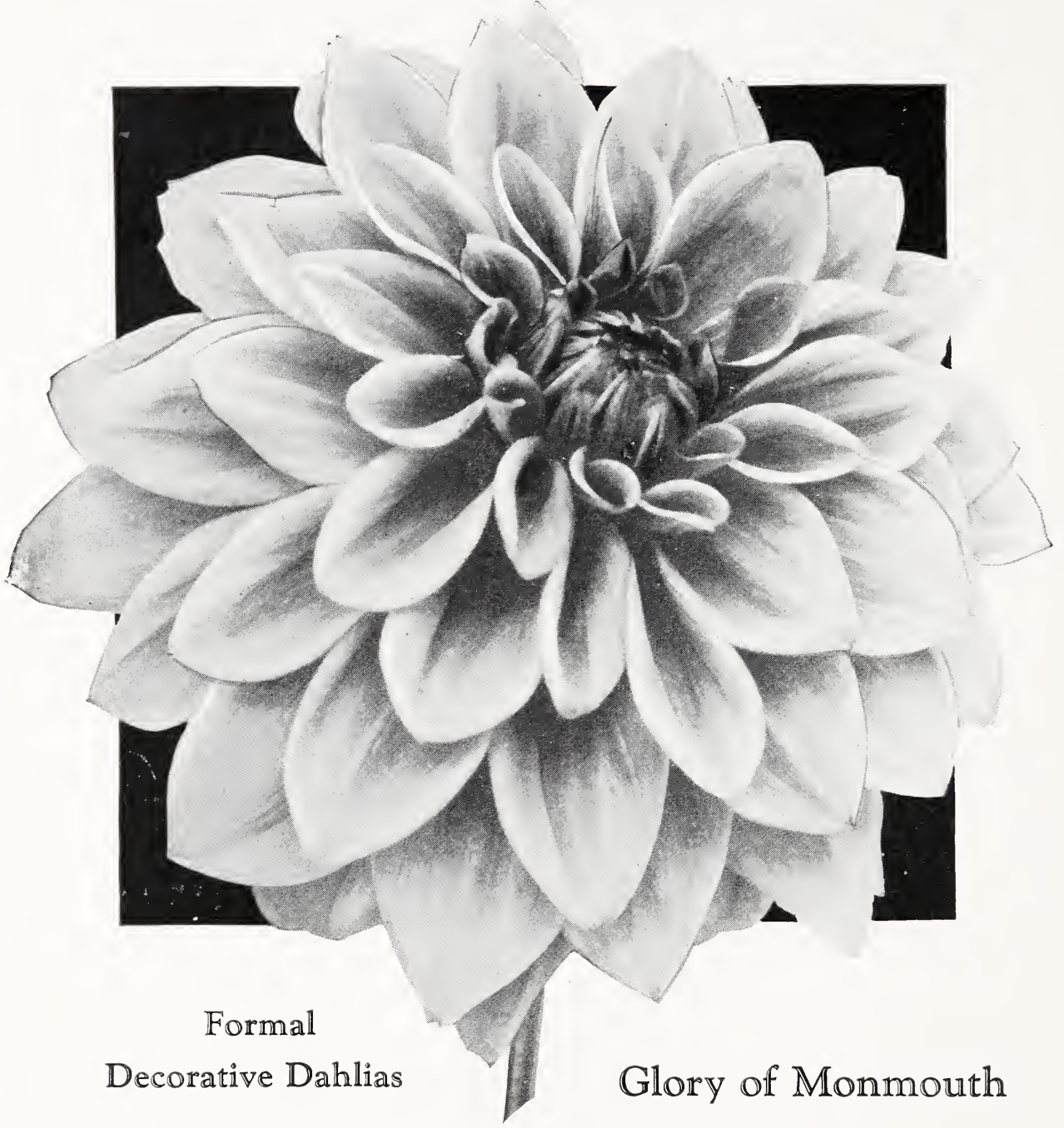

GLORY OF MONMOUTH (Kemp 85), g e, Bloom $8 \times 5$, Bush $5 \mathrm{ft}$. A beautiful salmon pink with light orange at the base of petals. The bush is of rather compact branching habit, literally covered with hlooms, making it a beautiful specimen. Flowers are of a heavy texture produced on long, sturdy stems. Good substance and artistic coloring make it a wonderful dahlia.

Tubers, \$2.50; Plants, $\$ 1.25$

CHAMPAGNE (Boston 83), $g$ e, Bloom $8 \times 4$, Bush $6 \mathrm{ft}$. A popular dahlia in the autumn shades. Color, golden champagne with chamois shadings. A good grower and free bloomer on erect stems.

$\$ 1.00$

HARRY MAYER (Reed 87), g e, Bloom $9 \times 4$, Bush $4 \mathrm{ft}$. A fine exhibition dahlia that holds an even full centre, has size, depth and strong stem. Bush grows sturdy but rather compact. Color, beautiful silvery pink with a rose pink reverse. An attractive and satisfactory dahlia.

Tubers, \$2.50; Plants, \$1.25

JANE HALL (Peacock 83), $c$ g, Bloom $6 \times 4$, Bush 41/2 ft. A full, high-centred decorative with petals reflexing to stem and keeping well when cut. Blooms well above the foliage on stout stems. Color, buff yellow with bronzy suffusion. 


\section{FORMAL DECORATIVE DAHLIAS-Continued}

KEMP'S LAVENDER (Kemp 83), $g$ e, Bloom $71 / 2 \times 4$, Bush $5 \mathrm{ft}$. Another free-blooming variety of regular form and good substance. The violet mauve flowers are large with full centres.

Tubers, \$2.50; Plants, \$1.25

M. F. HEAPHY (Murphy 79), g, Bloom $71 / 2 \times 4, B$ sh $5 \mathrm{ft}$. Large, deep flowers of velvety crimson carmine with reddish purple shadings. An early bloomer with good stems.

Tubers, \$1.50; Plants, $\$ 1.00$

MORDELLA (Kemp 75), g e, Bloom $9 \times 4$, Bush 7 ft. Apricot buff, beautiful under artificial light. Flowers large and gracefully formed on long stems.

$\$ 1.00$

ROMAN EAGLE (F. \& M. 87), c $g$ e, Bloom $10 \times 3$, Bush $5 \mathrm{ft}$. This popular dahlia is an uncoinmon autumn shade decorative of a brilliant burnished copper. A dahlia that does exceptionally well in medium to light soil. D. S. of N. J. Cert. A real winner on the exhibition table.

Tubers, $\$ 1.50 ;$ Plants, $\$ 1.00$

SUNNY JERSEY (Dahliadel 78), $g$, Bloom $7 \times 3 \frac{1}{2}$, Bush $4 \frac{1}{2} \mathrm{ft}$. An exceptionally free bloomer with flowers a foot or more above the foliage on erect stems. Color, lemon yellow, with golden suffusion.

ALL THE ABOVE VARIETIES ARE THE SAME FORM AS ILLUSTRATION

BRANCHING. Allow only one stalk to grow (never more than two). Pinch out the crown or centre above the second pair of leaves or eyes. The principle of taking out the centre is to develop the eyes, which are located at the base of the leaves between the stem and leaf. The top pair of eyes will make themselves evident in surprisingly short time, and these shoots or laterals on most varieties should be pinched back again, leaving one pair of eyes on each branch. By the time these get a start, the second or lower set of eyes on the main stalk will have developed along with the four above. These six stems should bear the first six flowers.

DISBUDDING. When the terminal bud on each of these stems is about the size of a small acorn, or as soon as the side shoots are large enough to pull out, disbud by taking out all the side buds and shoots except the lower pair on each of the six branches. Leave only one side shoot on each, should you desire very large flowers. These new branches should be handled as the previous set. All of the disbudded stem should be cut with the flower. This early disbudding and pruning is not solely for the benefit of the first six flowers, but mainly to keep the bush low and properly branched for the future crop.

Care should be exercised with late topping or cutting back not to open hollow stems so that water can get in and start stem rot. Should water get into the stalk, slit the stalk just above the ground with the point of a sharp knife, and by twisting the knife let the water out.

Certain varieties branch to excess. These should be thinned out at intervals of two weeks, and not more than six shoots allowed to come into bloom for the first flowers. This affords the plant better air circulation and sunlight.

STEM BORER. This black-and-white striped worm enters the stem above the ground and usually works upward and will be noticed in the early season by the shortening of the internodes, later on by wilting. Cut the plant off near the ground and get the borer with your knife. If the borer is below where you want to cut back, use a hooked wire from the top. A plant cut back not later than July 15th should be in full bloom early in September.

Should a plant be too large to cut back when borer is discovered, use Pyrethrol at strength of 4 ounces to gallon and inject with ear syringe. This will kill the borer or drive it out. Drain stalk out by slitting at the bottom to prevent stem rot. 


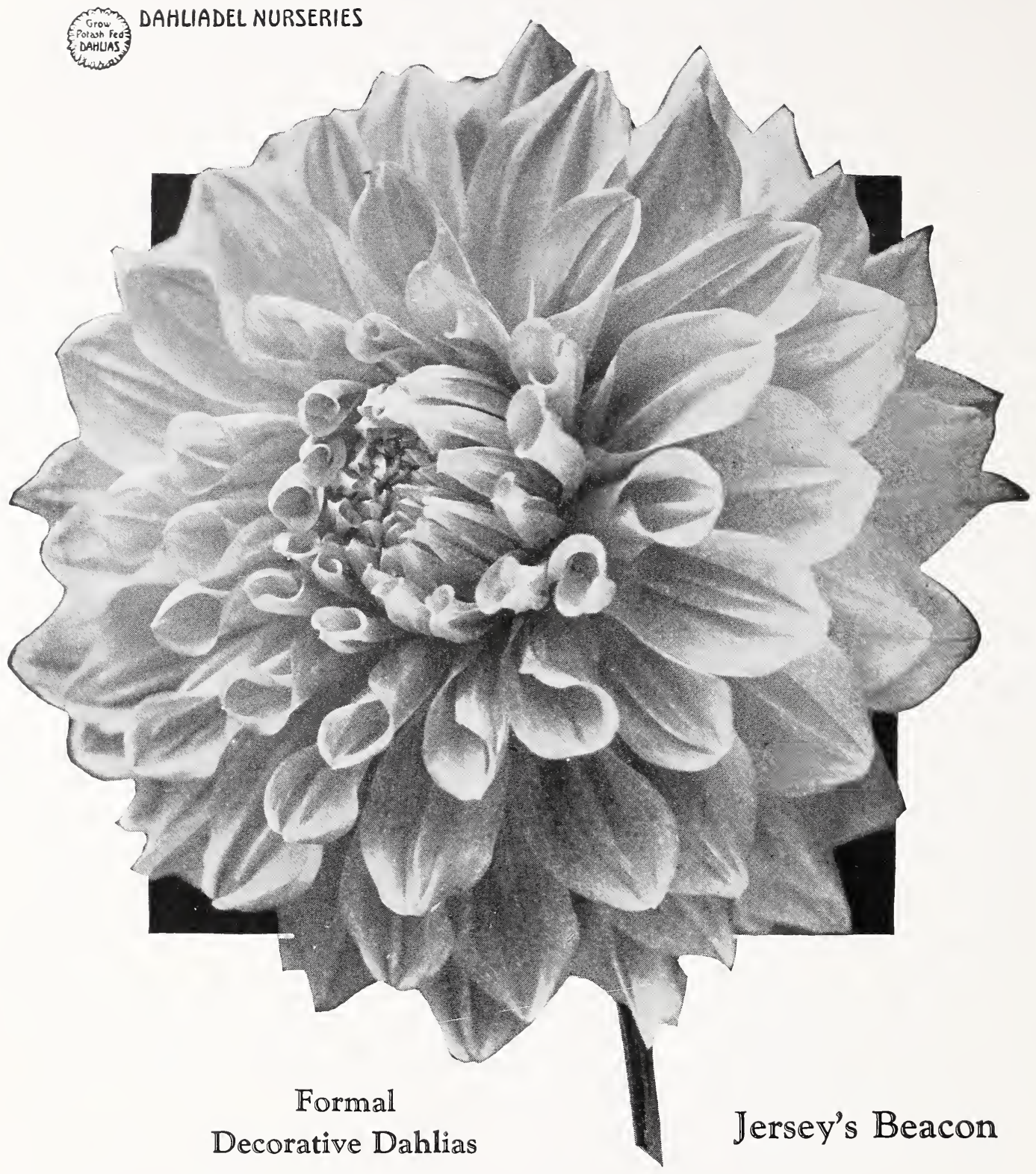

JERSEY'S BEACON (Waite 85), $g$ e, Bloom $9 \times 4$, Bush $41 / 2 f t$. The most spectacular of the Jersey family. Color, bright scarlet with a buff reflex, giving a two-tone effect. A free, early bloomer of extremely massive proportions with sturdy stems.

Tubers, $\$ 1.00 ;$ Plants, .50

EL DORADO (Boston 80), $c g$ e, Bloom $8 \times 4, B$ sh 41/2 ft. An all-purpose dahlia. Pure gold, deepening at the centre. Large, well-formed flowers held well above the foliage on good stems. A profuse and early bloomer.

$\$ 1.00$

ELIZA CLARKE BULL (Boston 82), $g$ e, Bloom $8 \times 4$, Bush $41 / 2 f t$. The largest white decorative from the West. A free bloomer, of perfect form and good substance that does not burn in extreme heat. Bush of medium height. A desirable variety with light green foliage.

Tubers, $\$ 2.00$; Plants, $\$ 1.00$ 


\section{FORMAL DECORATIVE DAHLIAS-Continued}

GRACE RICORDS (Ricords-Dahliadel), $c g e$, Bloom $8 \times 4 \frac{1}{2}$, Bush $51 / 2 f t$. This variety is outstanding, so different from anything else in form and color. Flowers are large, with full, high centres, tipped and suffused lavender on a white ground, petals numerous and decidedly cleft, giving the flower an artistic formation. A good strong grower and a variety that will stand extra feed and good culture for exhibition blooms.

Tubers, $\$ 10.00 ;$ Plants, $\$ 5.00$

NANAQUAKET (Richards 77), 1929, c g, Bloom $8 \times 4$, Bush $41 / 2 \mathrm{ft}$. This variety adds an orchid pink to this type of Decoratives and it certainly is a free bloomer, with flowers well above the foliage. A good garden variety.

Tubers, \$5.00; Plants, $\$ 2.50$

QUEEN OF THE GARDEN BEAUTIFUL (Burns 82), g e, Bloom $10 \times 4$, Bush 41/2 ft. This distinctive and interesting dahlia originated in the famous garden of the San Quentin Prison. An immense primrose yellow, facing upward on strong stems. An occasional bloom has a green centre, but it is so massive that we easily overlook the imperfection.

Tubers, $\$ 2.00 ;$ Plants, $\$ 1.00$

ROBERT TREAT (Muehler 80), $g$ e, Bloom $9 \times 4$, Bush $51 / 2 f t$. This dahlia, similar in color to the American Beauty Rose, is different from any other dahlia in shade or color. Plants are strong, healthy growers of spreading habit. Flowers produced freely on long, erect stems. \$1

THRIPS are tiny insects that enter the growing tip or shoot and chafe the newly formed leaves, injuring them so that they develop malformed and curled. These insects seem to enjoy the life blood of certain varieties on account of its flavor and do not molest the adjacent bush. If the attack is not checked it. will result in a stunted bush, which in reality is only debilitated by insect ravages.

LEAF-HOPPERS are larger than Thrips and of a pale yellowish green color, a little over $1 / 8$ of an inch in length. They fly when the bush is touched during the heat of the day. These sucking insects do much to keep a plant from getting a good start. They, as well as Thrips and Aphids, are common carriers of virus diseases and should be kept in control for this reason if for no other. During the windy weather when dust cannot be applied to advantage, overhead sprinklers used during the heat of the day will control red spider and check the LeafHoppers and Thrips.

We believe the best control of Thrips, Leaf-Hoppers and Aphids is by dusting with a good nicotine dust. Apply in sunshine with the temperature above 70 degrees at weekly intervals from the time the plants are set or tubers start to grow as a preventive, and if any should appear, then about every four days until they disappear.

Another good control method is to spray with Pyrethrol. This can be done at any time of day and regardless of weather conditions, except rain. We have found this very effective for Leaf-Hopper, Thrip, Red Spider and Aphids, 2 ounces to the gallon of water. For flea beetles, grasshoppers, ants and Japanese beetles, 4 ounces to the gallon. Should $a$ bush be infested with ants, spray bush and pour a teacupful of spray down the ant hill. This will do the dahlia no harm, but kill the ants.

By dusting or spraying before the presence of insects, it is doubtful if you will see any. As it is difficult to procure Nicotine Dust and Pyrethrol in most localities, we are listing them on page 42 of this catalog.

CUT WORMS are easily controlled by scattering about a teaspoonful of poison bran bait around the plant (but not touching it) as soon as plants are set or shoots appear from tubers. The early evening is the best time to apply it.

2 tablespoonfuls of molasses or brown sugar.

1 level teaspoonful paris green mixed in.

Juice of an orange or equivalent in water.

1 quart of bran or enough to make a reasonably dry mash. 


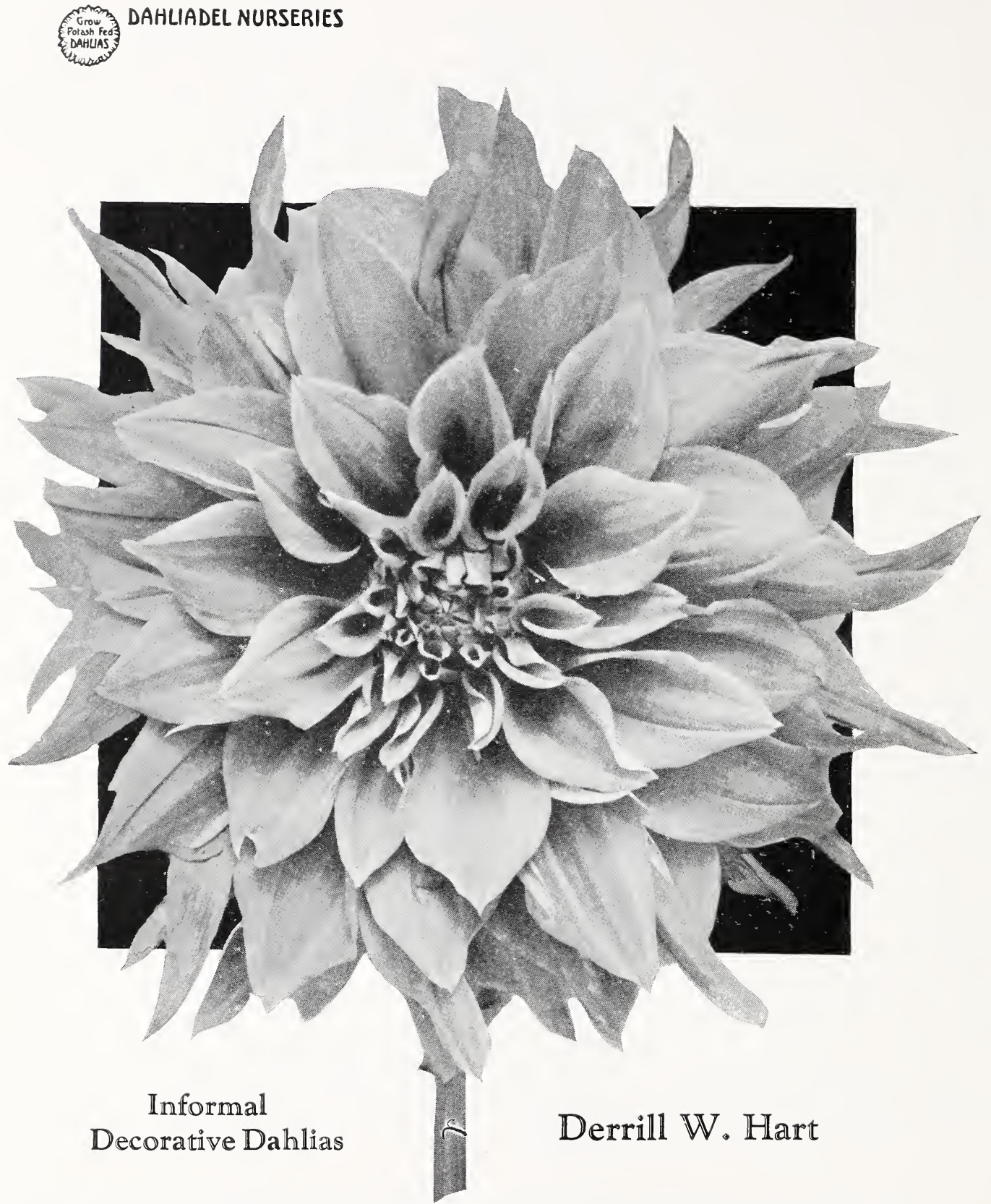

DERRILL W. HART (Broomall 89), 1929, c g e, Bloom 10 x 4, Bush 6 ft. We consider this the best dahlia Mr. Broomall has introduced. It is a wonderful grower, heavy, dark foliage and a free bloomer. Color, deep orange or copper, shading to henna brown. This dahlia is going to be a winner on the exhibition table, as it has a wonderful stem and keeps well when cut.

Tubers, $\$ 7.50$; Plants, $\$ 3.75$

AMARILLO GRANDE (Broomall 86), $g$ e, Bloom $11 \times 4$, Bush $5 \mathrm{ft}$. One of the large light yellow dahlias often found on the exhibition table. The flowers are well formed and held on strong, erect stems. A good grower.

Tubers, $\$ 2.00$; Plants, $\$ 1.00$

ANNA MARIE (Wiegand 85), g e, Bloom $6 \times 3$, Bush $6 \mathrm{ft}$. This dahlia's popularity is due to its attractive coloring of old gold suffused reddish salmon, distinctly tipped white. Flowers of good form on fine stems. This variety should be topped, as center crown blooms are apt to have green centres, but lateral blooms come good until frost. Tubers, \$2.50; Plants, \$1.25 


\section{INFORMAL DECORATIVE DAHLIAS-Contlnued}

COLOR SERGEANT (Hall 85), g e, Bloom $10 \times 4$, Bush 51/2 ft. This striking variety is becoming very popular. Color is unusual, being a rich, deep salmon bronze of one shade. A strong, upright grower with perfect stems. D. S. of N. J. Cert.

Tubers, $\$ 5.00 ;$ Plants, $\$ 2.50$

EARLE WILLIAMS (Doolittle 85), $c$ g e, Bloom $8 \times 4$, Bush $51 / 2 f t$. One of the best bi-colored dahlias. A pleasing scarlet distinctly tipped white with an occasional bloom solid red. Flowers deep and large with full centres of regular form on erect stems.

$\$ 1.00$

FORDHOOK BRIDESMAID (Burpee 85), 1929, c g e, Bloom $7 \times 4$, Bush $6 \mathrm{ft}$. This dahlia reminds you of Insulinde in form, with slightly broader and more irregular petals. Color, amaranth pink shading to a light pink at the base, with the centre of the flowers frosted silver.

Tubers, $\$ 3.50$; Plants, $\$ 1.75$

FAIRMONT (Kemp 80), 1929, c g, Bloom 71/2 x 3, Bush 51/2 ft. Pure pink, very similar to Delice in color. Well-formed dahlias are held well above the foliage on long, erect stems. Healthy and vigorous grower.

Tubers, $\$ 7.50$; Plants, $\$ 3.75$

GRANDOLA (Broomall 81), g e, Bloom $9 \times 4$, Bush $61 / 2 \mathrm{ft}$. This dahlia is very attractive, its color being a brilliant golden orange. The blooms are of good size held erect on fine stems, making a very desirable dahlia.

Tubers, \$2.00; Plants, $\$ 1.00$

HATHOR (Seal 80), g, Bloom $8 \times 3$, Bush $6 \mathrm{ft}$. A dahlia of vivid coloring, not red, but soft flame, shading to lemon yellow at the base of each petal. Blooms are large with pointed petals and artistic formation on erect stems.

Tubers, $\$ 2.00$; Plants, $\$ 1.00$

ISLAM PATROL (Davies 80), g, Bloom $7 \times 3 \frac{1}{2}$, Bush $51 / 2$ ft. The popularity of this unusual dahlia is due to its striking coloring. A very dark velvety scarlet tipped and flushed pure gold. Flowers are well formed on good erect stems, keeping well when cut.

$\$ 1.00$

JERSEY'S FIANCEE (Waite 80), $g$ e, Bloom $8 \times 4, B$ sh $6 \mathrm{ft}$. This variety will give you a lot of nice blooms. Color, rose pink with the points of the petals slightly tipped gold. A good, healthy grower, stems good.

Tubers, $\$ 1.50$; Plants, .75

KATHLEEN NORRIS (F. \& M.), c g e, Bloom $10 \times 5$, Bush $51 \frac{1}{2}$ ft. This outstanding exhibition dahlia is a true rose pink, deepening later to mallow pink with young central petals a lighter shade. Petals are broad and overlap each other with twisted tips. Blooms are held erect on long, strong stems. It is a healthy grower, having dark green leathery foliage, which is decidedly insect repellent.

Tubers, $\$ 10.00 ;$ Plants, $\$ 5.00$

LADY LYNDORA (Hall 84), g e, Bloom $9 \times 4$, Bush $31 \frac{1}{2} f$. This lovely dahlia is bound to become popular, especially in the pink class, as it is a pure pastel pink, with formation, size and stem to carry it through. Bush growth semi-dwarf, with exceptionally free blooming habits.

Tubers, $\$ 3.50$; Plants, $\$ 1.75$

MRS. D. M. RICHARDS (Wiegand 82), $g$ e, Bloom $8 \times 5$, Bush $5 \mathrm{ft}$. This new dahlia can be described as a Rose Nyron red or deep rose pink with golden apricot suffusion, which shows up well under artificial light. Bush strong, foliage leathery, stems long and erect. Blooms from early until late with full centres. A good keeper for cutting. Tubers, $\$ 2.50$; Plants, $\$ 1.25$

MRS. ELEANOR MARTIN (Pelicano 78), g e, Bloom $9 \times 3$, Bush $5 \mathrm{ft}$. A very striking and popular dahlia. A peculiar rose shade with reverse of violet, well described as "Mulberry." A profuse bloomer with good stems.

$\$ 1.50$

MRS. F. A. C. PERRINE (F. \& M. 78), g e, Bloom $9 \times 4$, Bush 6 ft. Another exhibition dahlia of the stag horn type. Petals curiously curled and twisted, terminating in sharp points.

$\$ 1.00$

NOBILIS (Doolittle 80), c $g$ e, Bloom $8 \times 3 \frac{1}{2}$, Bush $51 \frac{1}{2} f t$. Very similar to Earle Williams in form and color, except that the white predominates. Color, crimson and white. A real exhibition and commercial variety.

PRIDE OF DAHLIADEL (Dahliadel 78), $g$, Bloom $81 \frac{1}{2} \times 41 \frac{1}{2}$, Bush $51 / 2 \mathrm{ft}$. Color, a deep, non-fading carmine red somewhat similar to the Grizzly. Blooms are deep with full centres produced on strong, healthy bushes.

.75

WATCHUNG WONDER (Smith 88), 1929, g e, Bloom $10 \times 6$, Bush $5 \mathrm{ft}$. A spectacular dahlia of a rich royal red with a touch of gold at the centre of flowers, with an occasional yellow petaloid to enhance its beauty. Flowers might be described as being almost on the end of the stem and have unusual keeping qualities, for the back petals can be removed when withered and the centres will open out to perfect blooms.

Plants, $\$ 5.00$

A.l the above VARIETIES ARE THE SAME Form AS ILlustration 


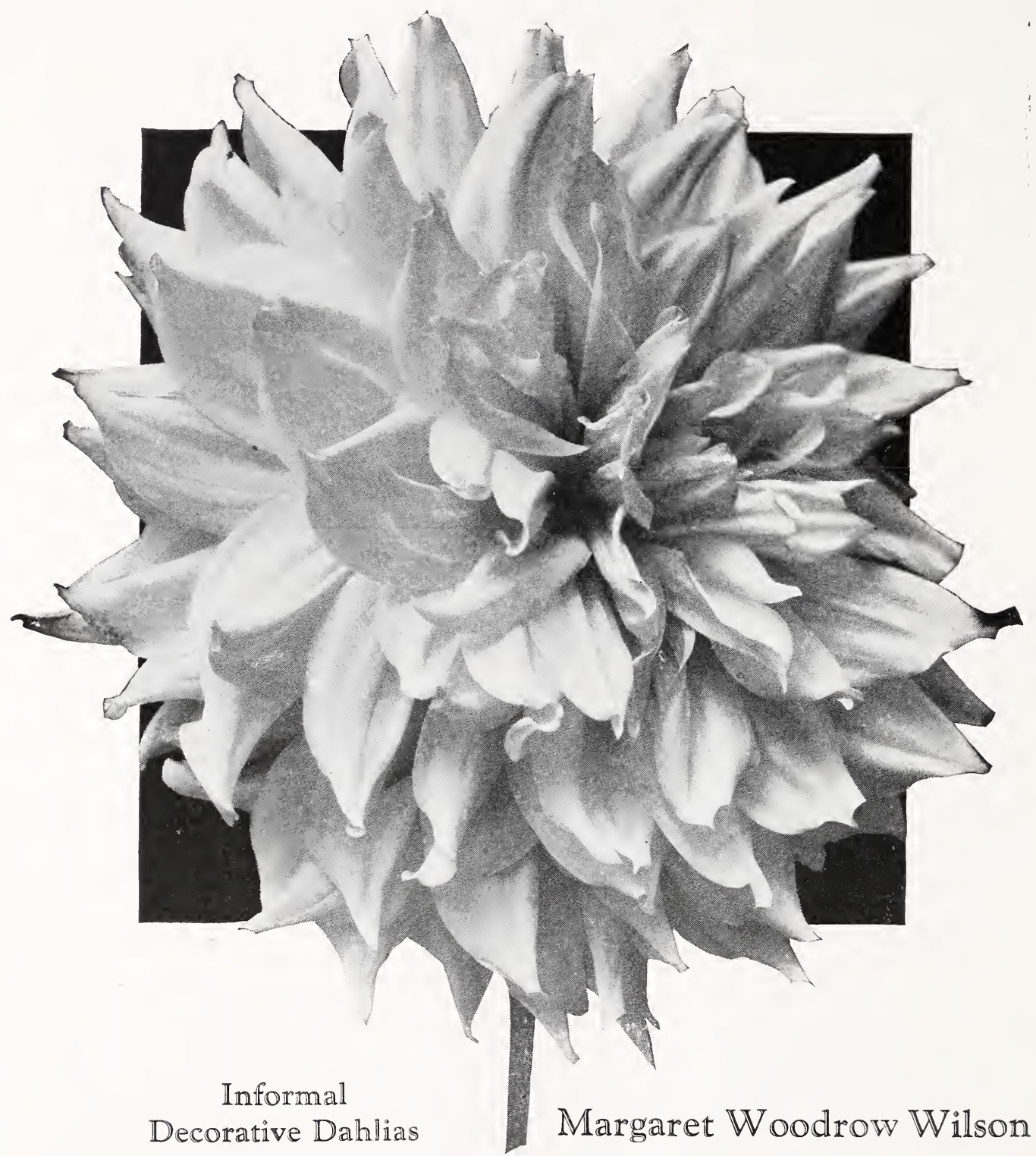

MARGARET WOODROW WILSON (F. \& M. 84), g e, Bloom $9 x 4$, Bush 41/2 ft. An exhibition decorative of immense size and wondrous beauty. Color, an opalescent pink. Face of petals creamy white with a phlox pink reverse. D. S. of N. J. Cert. A good grower and early and profuse bloomer.

Tubers, $\$ 1.50 ;$ Plants, $\$ 1.00$

AVALON (Broomall 80), c g e, Bloom $7 \times 3$, Bush $5 \mathrm{ft}$. This dahlia is good, although not new. Color, pure canary yellow on long, erect stems under normal culture. Excessive water and fertilizer will produce weak stems. Thinning out the bush is advisable shortly after topping.

AZTEC GLORY (Broomall 86), g e, Bloom $10 \times 5$, Bush $31 / 2 \mathrm{ft}$. We believe this to be the most spectacular yellow exhibition dahlia yet introduced. It is a clear picric yellow with deep, massive flowers of most artistic formation held on strong, erect stems. Foliage is glossy green, having somewhat the appearance of holly.

Tubers, \$5.00; Plants, \$2.50 


\section{INFORMAL DECORATIVE DAHLIAS-Continued}

BARBARA WEAR (Seal 83), $\boldsymbol{c} g$ e, Bloom $8 \times 4, B$ sh $51 / 2 f t$. A rather unique dahlia of artistic formation and good size. Color, soft violet rose with creamy white undershadings. Stems are long and erect. Bushes strong, healthy.

Tubers, \$5.00; Plants, $\$ 2.50$

CHAS. STRATTON (Stratton 83), g e, Bloom $9 \times 4 \frac{1}{2}$, Bush $61 / 2 \mathrm{ft}$. A blue ribbon winner in the largest bloom class. Flowers massive, keeping well when cut. Blooms early and profusely on strong stems. Color, pale gold shaded and tipped rose red.

$\$ 1.00$

FLORENCE KLEIN (F. \& M.), 1929, Bloom 7 x 4, Bush $31 / 2$ ft. Large, deep, full-centred dahlia of a salmon orange color shading deeper at centre. Flowers are held well above dark green leathery foliage on stiff stems. Free bloomer.

Tubers, $\$ 7.50 ;$ Plants, $\$ 3.75$

FORDHOOK VICTORY (Burpee 80), g, Bloom $8 \times 4$, Bush $4 \mathrm{ft}$. Blooms are large and graceful with full centers. Color, silvery Tyrian rose. Bush growth good with heavy foliage. Stems fair.

Tubers, $\$ 2.00$; Plants, $\$ 1.00$

JERSEY'S IDEAL (Waite 83), $\boldsymbol{g}$ e, Bloom $9 \times 5$, Bush $31 / 2 f t$. We consider this one of the best of the Jerseys. The flowers are held erect on strong stems. Leaves inclined to yellow in hot weather, but do well when dahlia weather comes on. Color varies between a lavender and Phlox pink overlaid with a decided silver sheen.

Tubers, \$1.50; Plants, .75

JERSEY'S SOVEREIGN (Waite 80), $g$ e, Bloom $71 / 2 \times 4$, Bush $6 \mathrm{ft}$. A dahlia worthy of anyone's growing. A good grower, early bloomer, of pleasing shade of salmon orange.

Tubers, .75; Plants, .50

KEMP'S VIOLET WONDER (Kemp 85), g e, Bloom $10 \times 5$, Bush $5 \mathrm{ft}$. The predominating color of this fine dahlia is Napthaline violet, with an undertone of royal purple, lightening to a faint bluish violet at the tips of petals. Deep flowers of perfect form. Stems are stiff, holding flowers a foot above the foliage. A truly outstanding variety, keeping well when cut. Plant is a prolific bloomer, strong grower, not susceptible to sucking insects. D. S. of N. J Cert. A. D. S. Gold Medal Ribbon.

Tubers, \$7.50; Plants, \$3.75

MRS. ALFRED B. SEAL (Seal 90), 1929, c g e, Bloom $11 \times 5$, Bush $6 \mathrm{ft}$. We believe this to be the finest dahlia of recent introduction from the West. Color, pure glowing old rose or violet rose, but wonderfully lighted without shadings or suffusion. It seems useless to tell all its virtues, as it seems to have them all and no faults, so we just know you will like it. It has the size, too, for exhibition.

Tubers, $\$ 15.00 ;$ Plants, $\$ 7.50$

NOTTINGHAM BEAUTY (80), $g$ e, Bloom $8 \times 3$, Bush $7 \mathrm{ft}$. A strong, vigorous grower. Color, true purple with white tips. Flowers of good form, size and very showy.

Tubers, \$2.50; Plants, \$1.25

OUR COUNTRY (Stillman 75), g, Bloom $8 \times 3 \frac{1}{2}$, Bush $51 / 2 \mathrm{ft}$. This deep, full-centred decorative is purplish red, tipped white. Stem semi-rigid but not erect, but even with this fault its coloring makes it popular.

$\$ 1.00$

POP STEWART (F. \& M. 84), $g$ e, Bloom $8 \times 3$, Bush $41 / 2 f t$. A very satisfactory dahlia, blooming early and late, on strong stems. A good grower, although not tall. Color, pure lilac pink and one $\mathrm{g}$ the best in thic rolor D. S. of N. J. Cert.

Tubers, $\$ 1.50$; Plants, $\$ 1.00$

SANHICAN'S BLUEBIRD (F. \& M. 80), $g$ e, Bloom $7 \frac{1}{2} \times 3 \frac{1}{2}$, Bush $41 / 2$ ft. A pleasing near to blue decorative with outer petals of bright violet blue, while the center petals retain the violet tint. An attractive flower on wiry stems.

Tubers, \$1.50; Plants, $\$ 1.00$

SANHICAN'S MAGNATE (F. \& M. 80), g e, Bloom $9 x$, Bush 3 ft. A splendid exhibition decorative of a pale amaranth pink, face of petals tinged with a deeper shade and the reverse of petals a solid claret color heavily veined. One of the "big fellows" on a dwarf bush. D. S. of N. J. Cert.

Tubers, $\$ 1.50$; Plants, $\$ 1.00$

SUSAN G. TEVIS (Boston 80), $g$ e, Bloom $8 \times 31 / 2, B u s h 5 f t$. This variety trends to the blue tones, but is a bright, rich lilac with bluish sheen. A vigorous grower, producing large, perfect blooms on fine stems through the season.

$\$ 1.00$

THE LEMONADE (Ward 80), $g$ e, Bloom $9 \times 4$, Bush $6 \mathrm{ft}$. Although we have a number of yellows, this dahlia is becoming very popular because of its beauty, size, erect stems, good habit of growth and wonderful keeping qualities. Color, clear sulphur yellow.

Tubers, \$2.00; Plants, \$1.00

WORLD'S BEST WHITE (Murphy 84), c $g$ e, Bloom $9 \times 3 \frac{1}{2}$, Bush $5 \frac{1}{2}$ ft. Although grown for a few years, this dahlia is still our best all-around commercial white and equally good for exhibition or the garden. The immense creamy white blooms are borne profusely on stiff stems.

$\$ 1.00$

ALL THE ABOVE VARIETIES ARE THE SAME FORM AS ILLUSTRATION 


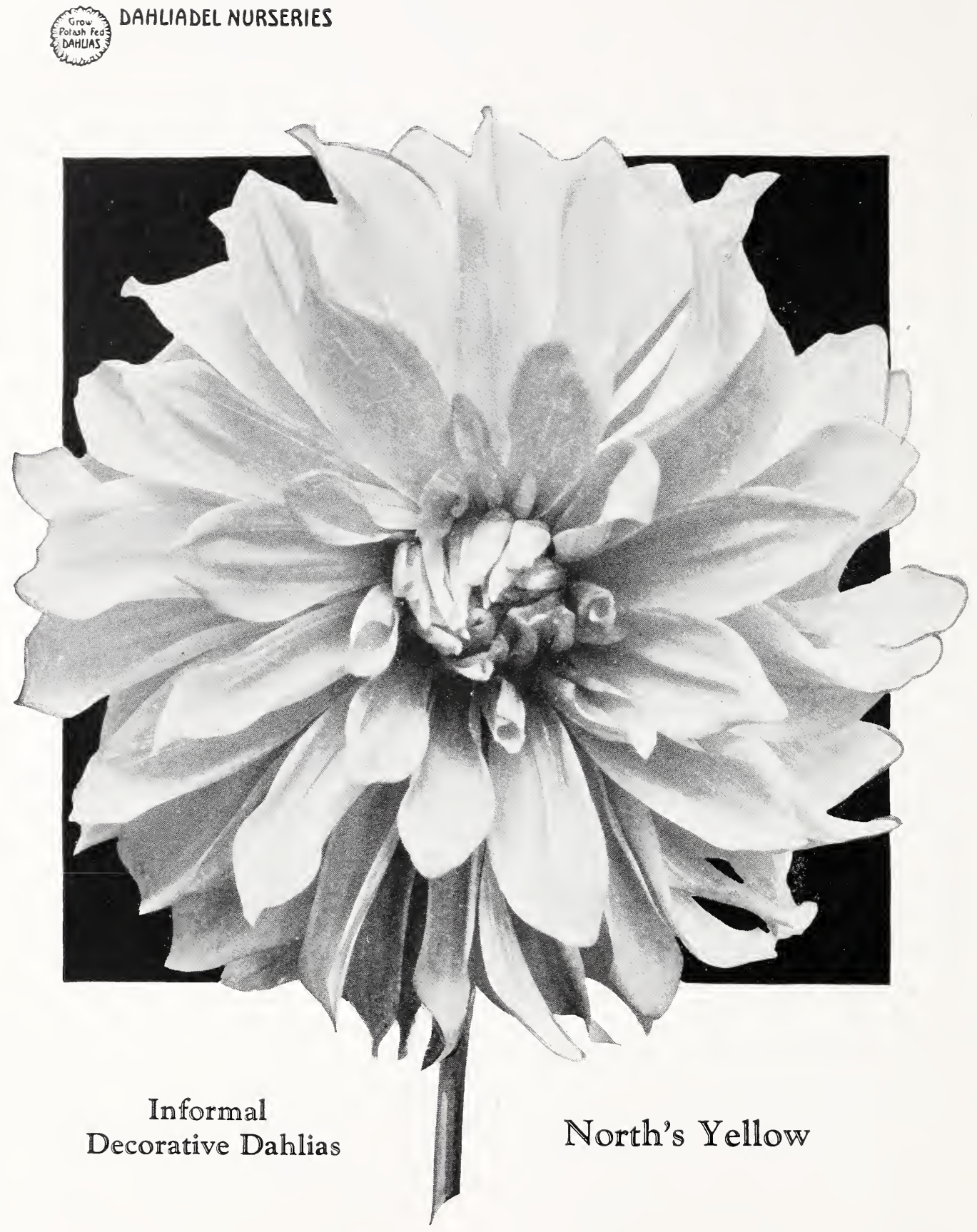

NORTH'S YELLOW (Peacock-Dahliadel 86), c $g$ e, Bloom $10 \times 4$, Bush $6 \mathrm{ft}$. This fine new 1929 introduction cannot help being a real favorite. It was in full bloom during August heat and seemed to like it, continued until frost and still had good-sized, full-centred blooms in quantities on long, slender yet strong stems. We can recommend it both South and North as a good grower. Flowers face nicely and form is good throughout the season. Color, a clear sulphur yellow without any shadings.

Tubers, \$5.00; Plants, \$2.50 


\section{INFORMAL DECORATIVE DAHLIAS - Continued}

CITY OF LAWRENCE (Reed 75), g, Bloom $81 / 2 \times 4, B$ sh $51 / 2 \mathrm{ft}$. A strong, growing variety, giving a lot of color in your garden. Flowers very large and deep, with full centres. Color, canary yellow. Stem fair.

COURONNE D'OR (Holland 80), c g, Bloom $7 \times 4 \frac{1}{2}$, Bush $6 \mathrm{ft}$. A dahlia that takes us back to Insulinde, for bush growth, stem and foliage are similar, even to color, which is rich golden apricot with reverse of petals rosy carmine, reflected through the flowers. A good keeper for cutting.

$\$ 1.50$

EVA COLE (Murphy 79), g e, Bloom $10 \times 4$, Bush $6 \mathrm{ft}$. The popular combination of red and gold. Exhibition flowers are large and artistic. Stem fair.

$\$ 1.50$

FLAMING METEOR(Baker 85), $g$ e, Bloom $8 \times 3, B u s h 5 f t$. This new dahlia is decidedly attractive owing to its unique form, bright color and good keeping qualities. The flowers have full centres and are borne in profusion on stiff, wiry stems. Color, deep cadmium yellow with heavy scarlet suffusion at the centre, the general effect being a flaming orange.

Tubers, \$2.00; Plants, $\$ 1.00$

GRACE JOCELYN (Kemp 80), $g$ e, Bloom $9 \times 4$, Bush 6 ft. This seedling of Mordella is an exquisite tone of Begonia rose and reddish salmon. Full-centred flowers with good stems. A healthy grower and prolific bloomer.

Tubers, \$5.00; Plants, $\$ 2.50$

INSULINDE (Kriest 79), $g e$, Bloom $8 \times 31 / 2, B u s h 6 f t$. An artistic dahlia of distinct form, with petals curled and twisted. Flowers mostly facing upward on long, strong stems. Color, a rich saffron yellow shaded russet orange.

JACK O'LANTERN (Reed 80), $g$ e, Bloom $9 \times 3, B$ sh $51 / 2 f t$. A bright spot in the garden. Petals are wide and twisted, of a brilliant orange-red, shading to a dark Spanish red near the centre. The petals that form the centre are tipped with gold, making the general effect very bold and brilliant. A good grower and bloomer.

Tubers, $\$ 2.50$; Plants, $\$ 1.25$

MARMION (Tyler 85), $g$ e, Bloom $11 \times 4, B$ sh $6 \mathrm{ft}$. A giant dahlia of lovely coloring. Pure golden yellow with a bronze centre, and reverse of petals reveals a bronze suffusion. The blooms are held on good stems well above the foliage of the sturdy, strong-growing plant. Good exhibition variety.

Tubers, $\$ 2.00$; Plants, $\$ 1.00$

PRIDE OF STRATFORD (M. \& S. 76), g e, Bloom $9 \times 4$, Bush $5 \mathrm{ft}$. A fine, large dahlia inclined to be a little bashful, the bloom tipping somewhat at the neck. Form is very good, centres full and color cadmium orange shaded light orange yellow at base of petals, reverse rose doree.

Tubers, $\$ 1.50 ;$ Plants, $\$ 1.00$

REGAL (Boston 86), 1928, $g$ e, Bloom $10 \times 5$, Bush 41/2 ft. Bronze heavily suffused with dull old rose, with gold shadings at base of petals, giving it a burnished copper effect. Blooms profusely on long, rigid stems well above the foliage. A dahlia we think a great deal of.

Tubers, \$10.00; Plants, $\$ 5.00$

ROOKWOOD (Boston 78), g e, Bloom $8 \times 3, B$ sh $4 \frac{1}{2}$ ft. Pure, bright cerise rose without any suggestion of magenta. Immense flowers of good depth held aloft on splendid straight stems. A free and early bloomer.

$\$ 1.00$

SEAL'S CALIFORNIAN (Seal 84), 1929, $g$ e, Bloom 91/2 $x$ 5, Bush $31 / 2$ ft. Broad petal beautifully formed with tiny petaloids of light yellow give flowers an artistic break. Bright golden yellow at centre, shading lighter toward outer petals; tips are suffused very lightly with a bronze rosy pink. Held proudly on strong cane-like stems. Tubers, $\$ 7.50$; Plants, $\$ 3.75$

WIZARD OF OZ (Doolittle 78), g, Bloom $9 \times 3$, Bush $6 \mathrm{ft}$. A pleasing shade of glowing amber pink, shaded salmon. Has good stems by disbudding.

$\$ 1.00$

STUNT. In our twenty years with dahlias, we have dug and destroyed all unhealthy stock as soon as detected, and the results are most gratifying. This is properly called roguing. As there are a number of causes for stunt, it is hard to tell the exact cause. However, we do know that roguing is the only practical way of eradication, and believe some of the causes of stunt may be attributed to one or more of the following conditions:

First: From lowered vitality as a result of poor culture, lack of cultivation, etc.

Second: The ravages of attacking insects, Thrips, Leaf-Hoppers, Stem Borers, etc.

Third: The rotting of the feed roots caused by too much water where drainage is poor, or water in the hollow part of the stem.

Regardless of cause, all stunt should be dug and destroyed. Our many years of this practice leaves us less than $1 \%$ to dig annually on most varieties. 


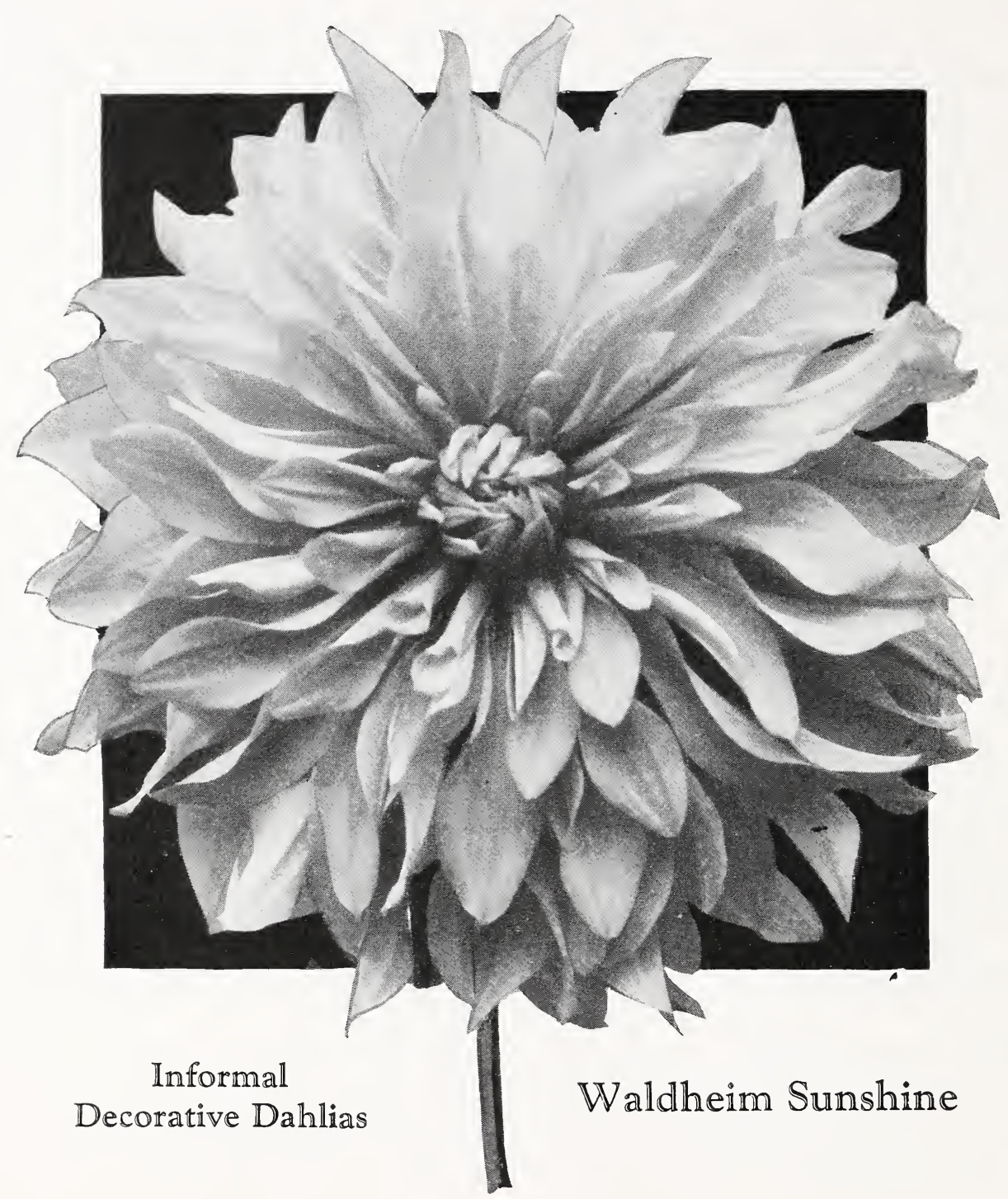

WALDHEIM SUNSHINE (Peacock 85), c g e, Bloom $10 \times 41 \frac{1}{2}$, Bush 51/2 ft. This giant yet graceful dahlia is one of the best. A true deep yellow that will show up yellow under artificial light. The reflex is darker, and there is a rich golden suffusion around the beautiful full, high centre. The bush growth is good, stems are strong and erect. It is a sturdy grower and free bloomer. The centres were perfectly full when killed by frost. Illustrated on inside back cover.

Tubers, \$7.50; Plants, $\$ 3.75$

ALTAMONT (Kemp 79), g e, Bloom $10 \times 4$, Bush $7 \mathrm{ft}$. Large, full flowers with long, slightly curved petals of artistic formation. Stems are long and slender but rigid. Flowers are good keepers and different enough to appeal to you. Color, rose pink, deepening to American Beauty rose at the centre of the flower. 


\section{INFORMAL DECORATIVE DAHIIAS-Continued}

BIG CHIEF (Reed 85), 1929, g e, Bloom $10 \times 5$, Bush 5 ft. A massive and yet rather attractive dahlia on strong, erect stems. Stands a good chance of winning in the largest bloom class. Color, salmon buff with rose shadings. Bush healthy and strong. Tubers, \$7.50; Plants, \$3.75

CHARLOTTE LAFRENZ (Seal 84), c g e, Bloom $10 \times 31 / 2$, Bush $6 \mathrm{ft}$. The petals are long, partially fluted and then twisted, which gives the flower an unusual form. Color, gold with rose red and apricot shadings. Flowers are held high on long stems, bush a strong grower.

Tubers, $\$ 5.00 ;$ Plants, $\$ 2.50$

EL GRANADA (Boston 80), $g$ e, Bloom $8 \times 3, B u s h 41 / 2 f t$. A beautiful, vivid orange dahlia with creamy white tips. Petals twist and interlace, giving it a very artistic form. Long stems hold the flowers well out of the foliage. Not an exceptionally early bloomer, but cannot be classed as late. A very attractive dahlia.

$\$ 1.00$

FRANCESCA (Carbone-Davis 83), 1928, $g$ e, Bloom $8 \times 31 / 2, B u s h 6 f t$. This artistic and perfectly formed dahlia is a combination of old gold and rose pink with violet suffusion, making it an interesting color combination. Long stems, healthy grower and free bloomer make it a very attractive dahlia. Tubers, \$4.00; Plants, \$2.00

JERSEY'S EMPRESS (Waite 82), g, Bloom $9 \times 31 / 2$, Bush $51 / 2 \mathrm{ft}$. A large anthracene violet dahlia of pleasing formation, having narrow and wavy petals. Good depth and substance. Color is almost sunproof. Stems fair.

Tubers, \$1.50; Plants, .75

JUDGE SHINN (Kemp 83), $g$ e, Bloom $8 \times 31 \frac{1}{2}$, Bush 7 ft. Color, a pleasing combination of gold and salmon, gold predominating at the centre and salmon in the outer petals. This dahlia was named for the Hon. C. C. Shinn, an ardent dahlia fan, of Atlantic City. It is fine for background planting, as it is a tall, vigorous grower.

Tubers, \$7.50; Plants, \$3.75

KING MIDAS (Peacock 85), 1929, $g$ e, Bloom $10 \times 4$, Bush $4 \mathrm{ft}$. We believe this to be one of the best pure golden yellow dahlias grown. It has a full, high centre to the end of the season. Stems erect and plant growth sturdy. A decidedly good exhibition or garden yellow.

Tubers, $\$ 10.00 ;$ Plants, $\$ 5.00$

MRS. GEO. W. ELKINS, JR. (Root 75), $g$ e, Bloom $8 \times 31 / 2, B u s h 4 f t$. The flowers are large and deep, with full centres, borne on good stems. It is a free and open grower. The color is beautiful old gold, suffused with salmon pink with a faint reflex of rosy pink.

.75

MRS. JAS. A. BABBITT (Root 82), c g, Bloom $9 \times 3 \frac{1}{2}$, Bush $51 \frac{1}{2}$ t. Flowers of immense size with incurved petals. Color, deep yellow with reverse of petals overlaid with crimson. A dahlia with many friends.

.75

PAPILLON (Boston 79), $g$ e, Bloom $8 \times 3 \frac{1}{2}$, Bush $51 / 2$ ft. Described as an improved George Walters, which it resembles, although quite different in coloring. Beautiful old rose illuminated with golden lights.

$\$ 1.00$

RODMAN WANAMAKER (Peacock 82), c $g$ e, Bloom $10 x 3$, Bush $51 / 2 f t$. One of our strongest growing varieties, producing large flowers on long, strong stems. Buds are a pale yellow, but as the flower expands develop into a bronzy salmon pink. This variety has a real peony centre, which does not detract from its beauty. Tubers, $\$ 1.50$; Plants, $\$ 1.00$

SANHICAN'S NYMPH (F. \& M. 84), $g$ e, Bloom $8 \times 4$, Bush 5 ft. A dahlia suitable for exhibition. It is a deep flower with a very full centre. Color, a beautiful primrose yellow with a shade of fawn rose on the reverse of petals, the latter color showing up more clearly at the centre of the flower. Flowers face upward on strong stems. Tubers, $\$ 5.00$; Plants, $\$ 2.50$

THE GRIZZLY (Burns 79), $g$ e, Bloom $8 \times 31 / 2, B$ sh 6 ft. One of the popular dark red decoratives. Tall-growing exhibition variety and a prize winner with long reflex petals. Color, velvety crimson maroon.

.75

TY COBB (Peacock 80), 1929, g, Bloom $8 \times 5$, Bush $5 \mathrm{ft}$. This well-formed dahlia is brilliant glowing garnet shading deeper with a lustrous sheen and reflex of reddish violet. Strong plant of dark green, glossy leaves. A showy garden variety producing an abundance of flowers on fairly good stems.

Plants, $\$ 2.50$

WHITE EMPRESS (Jost), c $g$ e, Bloom $8 \times 5, B u s h 51 / 2 f t$. This 1929 introduction bids fair to be the best all-around white yet introduced. It is a strong, healthy grower with flowers held well above the foliage on strong stems. It won the Darnell Cup at New York for the best keeper and should prove very popular for florists' use and on the exhibition table.

Tubers, \$7.50; Plants, \$3.75

WONDERLAND (Bissell 78), g, Bloom $10 \times 3$, Bush $6 \mathrm{ft}$. Flowers are of large exhibition type, deep, velvety garnet purple, reverse light rosy magenta. Petals are twisted and curled, making a two-toned effect.

Tubers, $\$ 2.00$; Plants, $\$ 1.00$ 


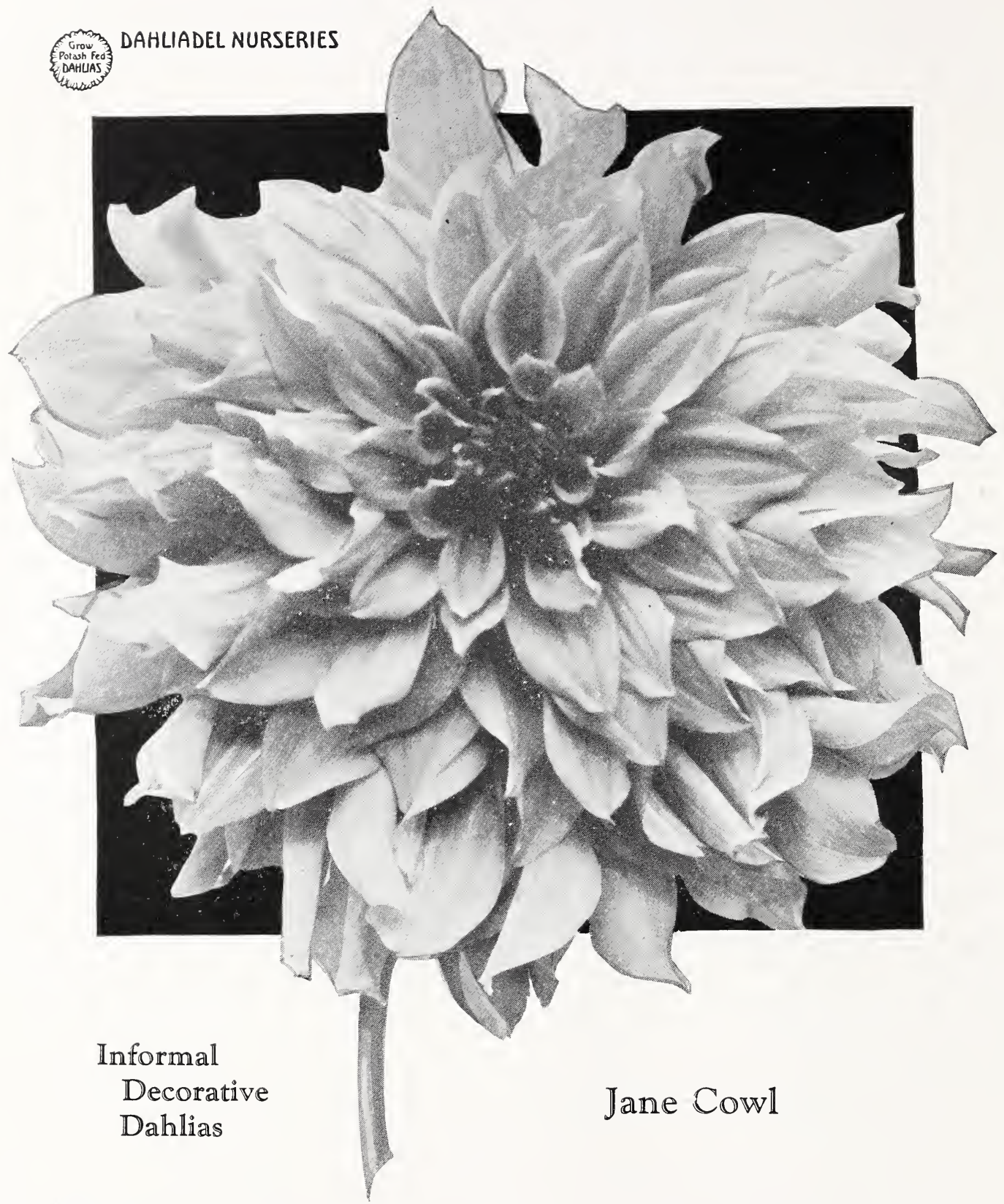

JANE COWL (Downs 90), $g$ e, Bloom $10 \times 6$, Bush 51/2 ft. This wonderful new dahlia has been a success wherever grown the past season and is one of the most talked of novelties. Color, a warm buff and old gold, blending to apricot and rose at the centre. Bush growth is ideal with strong stems holding the giant flowers upright. A dahlia that is sure to please you, for it is large and impressive. A. D. S. Cert.

Tubers, $\$ 7.50 ;$ Plants, $\$ 3.75$

COQUETTE (F. \& M. 86), 1929, c g, Bloom $10 \times 6$, Bush $5 \mathrm{ft}$. A very spectacular dahlia of Spanish coloring, bright red blending with gold. Petals twist and curl, showing the golden reflex. Blooms keep well if fully matured when cut. The heavy dark green foliage makes it insect-resistant. Free bloomer on long stems.

Tubers, $\$ 6.00$; Plants, $\$ 3.00$

MARTHA KEMP (Kemp 84), 1928, c $g$ e, Bloom $8 \times 5$, Bush 5 ft. A very pretty pastel combination of warm buff shading apricot yellow at base. Flowers deep and artistic, held on long, erect stems. A good grower and bloomer.

Tubers, \$7.50; Plants, \$3.75 


\section{INFORMAL DECORATIVE DAHLIAS-Continued}

MILDRED BROOKS HOOVER (Broomall 83), 1929, g e, Bloom 10 × 5, Bush 41/2 ft. This dahlia is distinctive because of its unusual formation. Color, reddish violet or described by some as Spinel red. Stems are strong and hold the blooms well out of the foliage. This variety will remind you of Rosa Nell, with larger blooms of a shaggy formation.

Tubers, \$7.50; Plants, \$3.75

MRS. KENYON (Harding 86), 1929, g e, Bloom $9 \times 4$, Bush 41/2 ft. A dahlia you will be pleased with, as it is a rich salmon to peach pink, shading to orchid at the tips. It is a strong, healthy grower with leathery foliage. Flowers held facing partially upward on strong stems.

Tubers, $\$ 7.50 ;$ Plants, $\$ 3.75$

SANHICAN'S PEACH (F. \& M. 80), g e, Bloom $81 / 2 \times 4$, Bush $4 \frac{1}{2} f t_{\text {. }}$ A charming, fluffy decorative. In color it is a reddish salmon with buttercup shadings, reminding one of a ripe California peach. Its attractiveness is further enhanced by the oddly twisted petals. Rich dark green foliage, upright stems and good habit of growth. Tubers, $\$ 3.00$; Plants, $\$ 1.50$

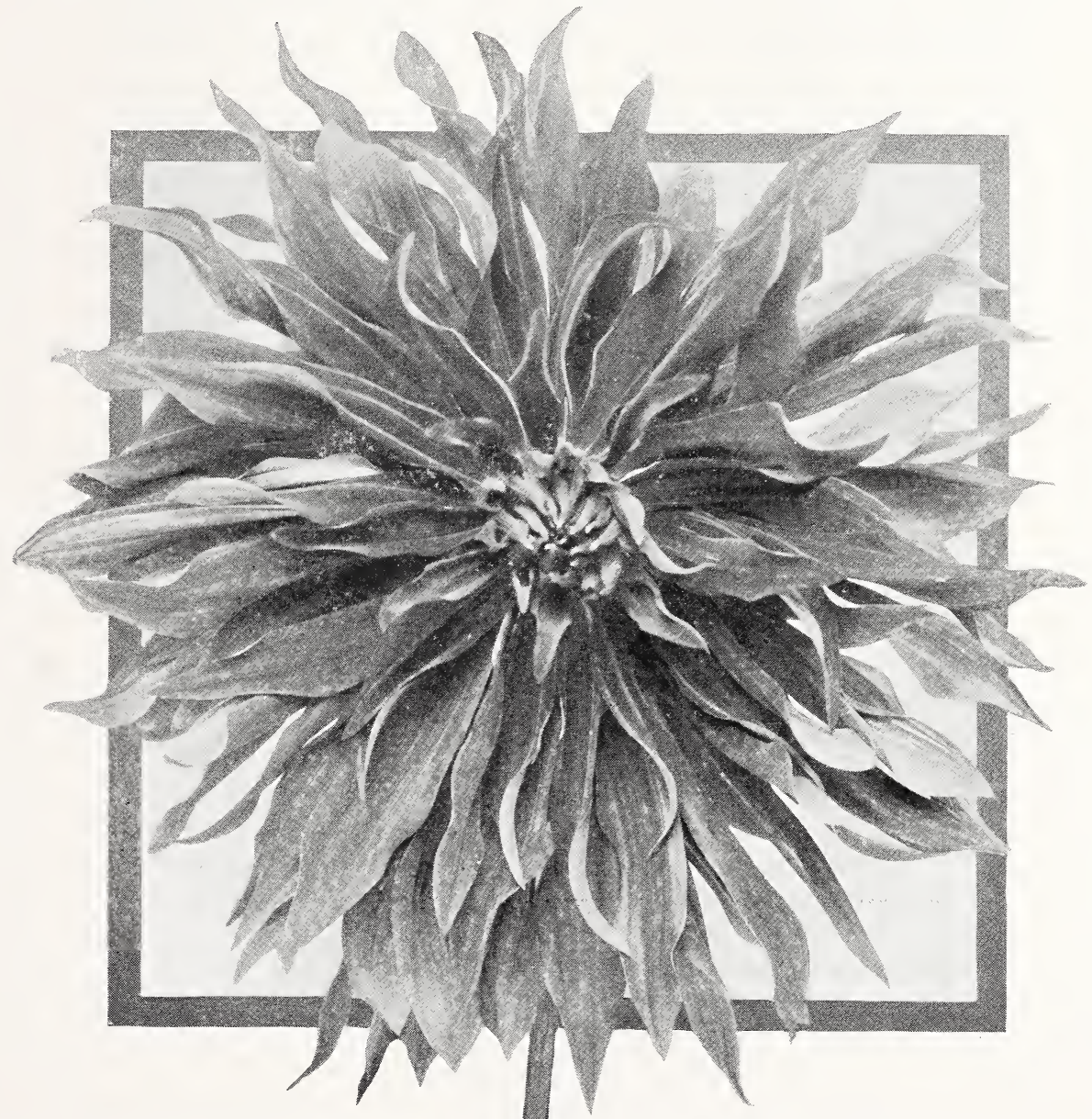

FORT MONMOUTH (Kemp 90), 1928, ge, Bloom $11 \times 4$, Bush 61/2 ft. This giant dahlia was even a greater winner at the shows this year than last. The predominating color is rich claret with brightness, unusual in darker tones. Flowers are full centred and well formed, borne on long, stiff stems high above the foliage. A very prolific grower and bloomer. The new classification has changed this dahlia to the Informal Decorative Class, but it will continue as a winner.

Tubers, \$7.50; Plants, \$3.75 


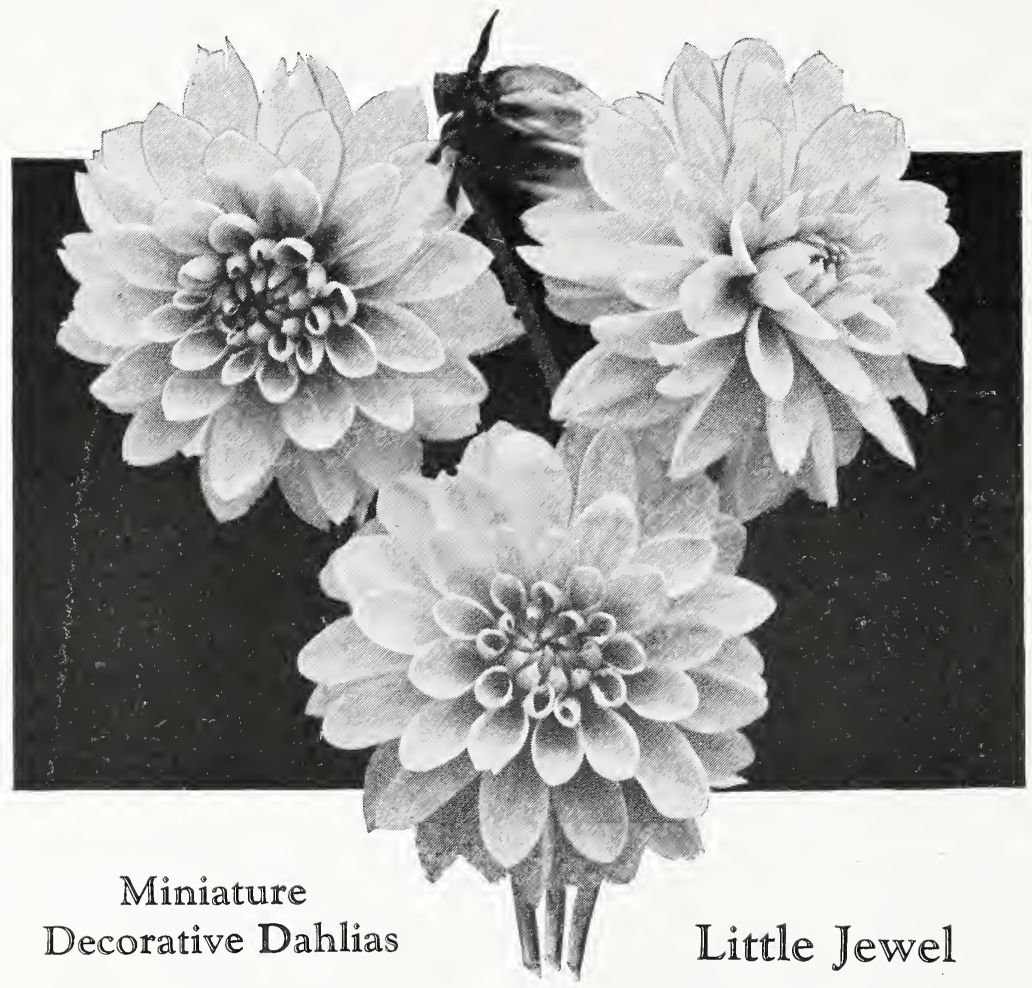

LITTLE JEWEL (Papendricht 86), $c$ g, Bloom $2 \times 1$, Bush 3 ft. A miniature decorative. Popular as a cut flower, especially for decorations. Color, a pleasing peach blossom pink. This dahlia is not a seedling, but a sport of Delice and very similar in color.

\section{Cut Flowers}

Dahlias should be cut in the evening or early morning, removing the lower leaves and all of the buds if not disbudded. Immediately put in water in a cool, dark place to freshen.

Hot-Water Treatment-Cut and freshen as above, then put stems in 1 to 2 inches of water almost boiling for 1 to 2 minutes, then place in deep cold water to cool. Flowers are then ready to ship by packing in a strong corrugated box lined with tissue paper. Fasten stems down by nailing a wooden strip in the center of the box or by tying down through the bottom. Flowers packed snugly will carry better than when packed loose and allowed to batter.

Flowers when wilted can be freshened by cutting end of stem and placing in hot water as above. Repeat until flower is freshened.

The hot-water treatment will do wonders in making your exhibition blooms keep fresh after staging, but do not cut off the discolored end of stem unless you are again going to treat it.

The physical action of a cut flower is to take water up into the stem which evaporates through the flower and foliage. The slower this action of evaporation or transpiration takes place, the longer the life of the flower. 


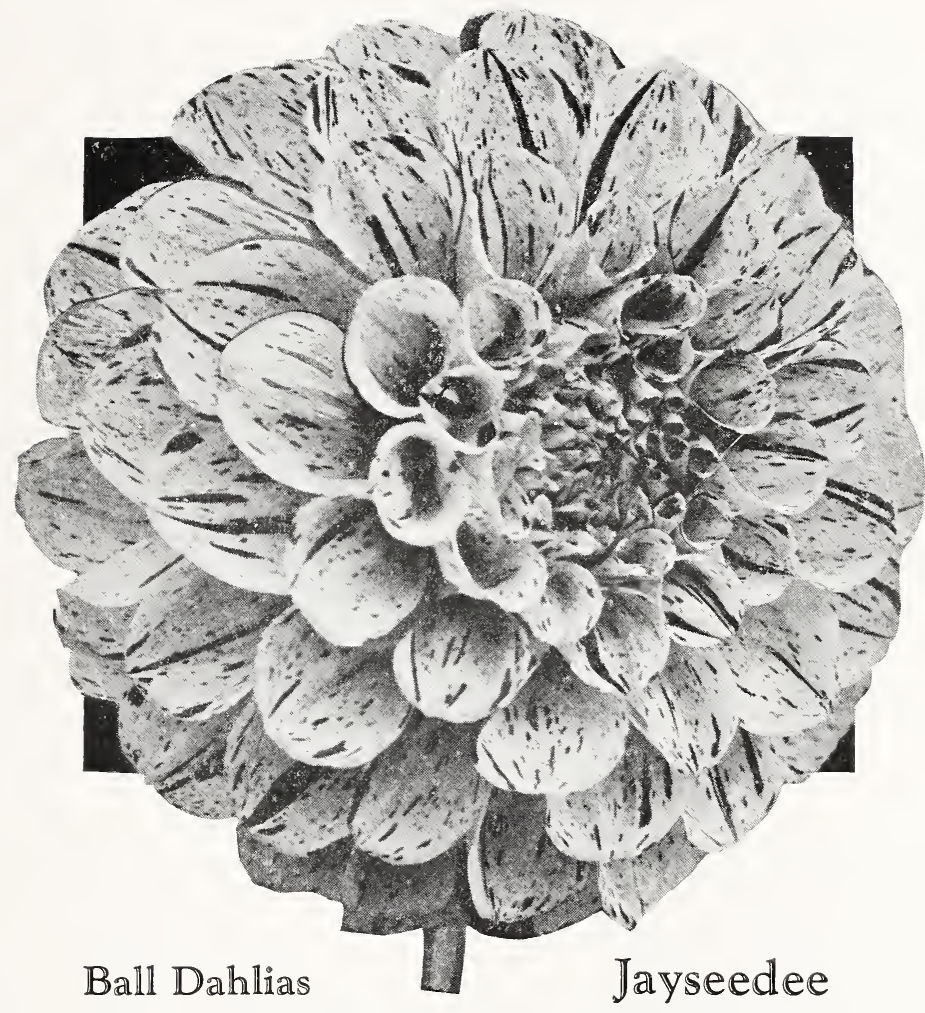

JAYSEEDEE (Draude 86), $g$ e, Bloom 41/2 $\times 3$ 1/2, Bush 41/2 ft. A beautiful ball-shaped dahlia of soft reddish violet striped and speckled rich deep red. A perfect ball. Bush compact, but fine stems can be produced by disbudding. A winner on the exhibition table.

CARL OWEN (Dahliadel 85), $g$ e, Bloom $5 \times 31 \frac{1}{2}$, Bush 5 ft. The best red show we have found. Rich, non-fading carmine red. Flowers of perfect form on erect stems. Good with disbudding.

DRAUDE (Draude 79), $g$ e, Bloom $5 \times 4$, Bush $4 \frac{1}{2} f t$. The finest dark red ball dahlia of perfect form. Bush rather dwarf with nodes very close; requires disbudding to produce long stems.

FLORENCE (Pfeiffer-Dahliadel 81), g e, Bloom $5 \times 3$, Bush $4 \frac{1 / 2}{f t}$. This variety is always a mass of blooms. Perfect form and good size. Color, a very pleasing shade of pale light lilac.

GOLD MEDAL (Keynes 87), c g e, Bloom 41/2 x 3, Bush 41/2 ft. (Improved Gold Medal.) Sunflower yellow tipped and suffused Oriental red; very striking and becoming more popular each year, both in the cut flower market and on the exhibition table. 


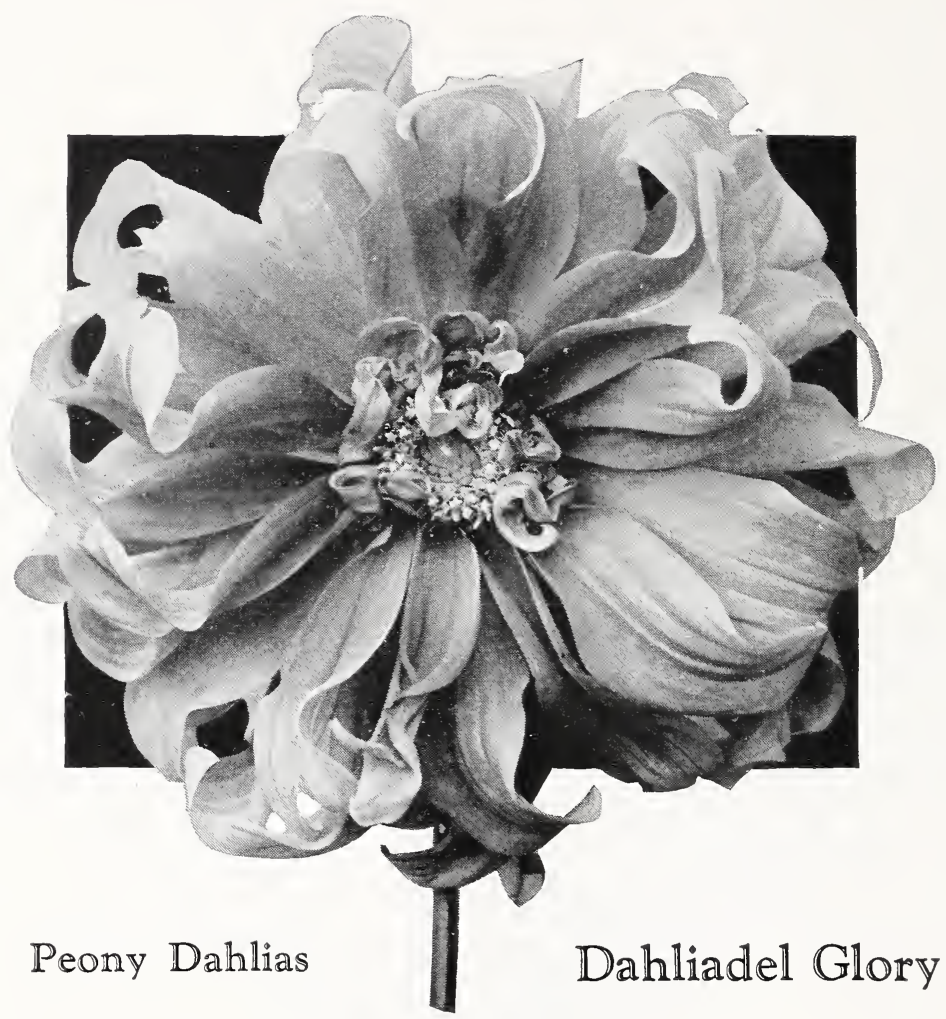

DAHLIADEL GLORY (Dahliadel 82), $g \boldsymbol{e}$, Bloom $8 \times 3$, Bush $41 / 2 f t$. This fine dahlia has a very artistic formation of broad, heavy petals, with a beautiful whirl centre, on long, erect stems. A wonderful color blending of scarlet tipped reddish apricot, giving a henna effect.

Plants, .75

CANADA (Peacock 78), g, Bloom $7 \times 3$, Bush $41 / 2$ ft. One of the best and hardiest pure white peonies. Bush dwarf but produces an abundance of blooms on erect stems well above the foliage.

CITY OF PORTLAND (Chamberlain 80), $g$ e, Bloom $8 \times 5, B$ ush $51 / 2 \mathrm{ft}$. The best and largest clear yellow peony dahlia we have found, producing exhibition blooms from early to late on erect stems.

DRUM MAJOR (Derre 82), $g$ e, Bloom $8 \times 21 / 2, B$ sh $4 \mathrm{ft}$. A rich, fiery red with a lemon yellow centre and petals more or less tipped and marked yellow. A bright and showy variety in the garden.

$\$ 1.00$

MRS. FRANCES E. BULLARD (Broomall 83), $g$ e, Bloom $9 x 4, B u s h ~ 4 \frac{1}{2} f t$. This is the largest peony in our list. The petals are long, pointed and gracefully twisted, forming a very distinct flower of a clear silver or pastel pink, shading lighter at the centre. First blooms usually come with full centres. Free, early and profuse bloomer on strong stems.

Tubers, \$1.50; Plants, .75

THE U. S. A. (Stillman 80), $g$ e, Bloom $8 \times 4, B u s h ~ f t$. An old dahlia but a good seller. It is a peony dahlia, but in general form it resembles the picture of Jane Cowl. Color, a vivid orange. An early, free bloomer. 


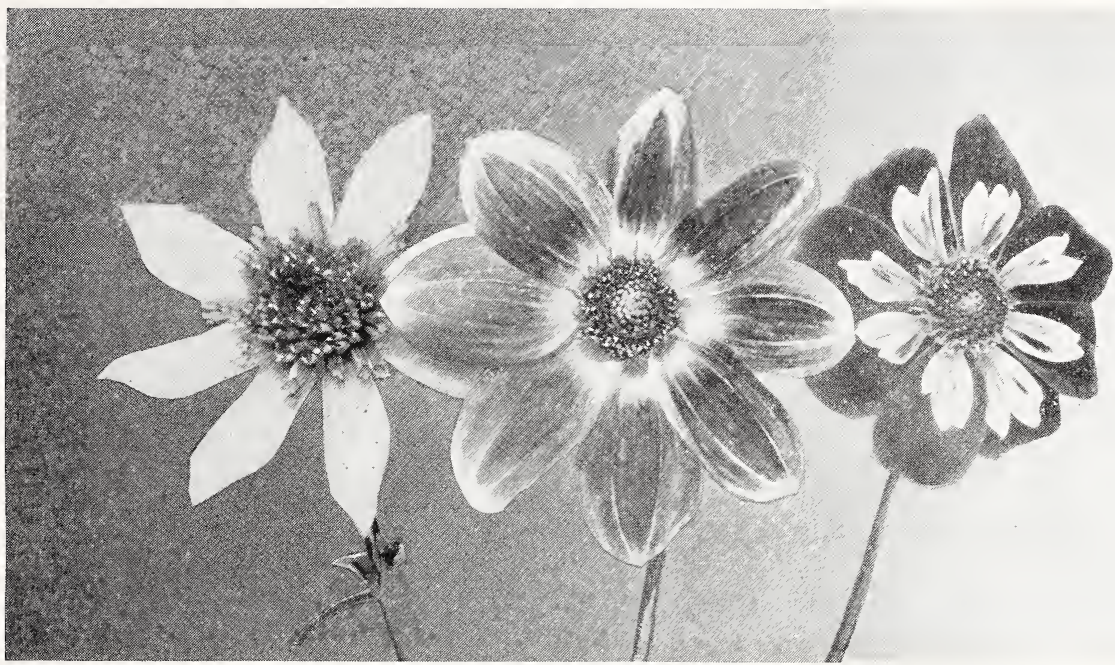

ANEMONE

SINGLE

COLLARETTE

\section{Anemone Dahlias}

ADA FINCH (Wouters 83), g, Bloom 31/2, Bush 21/2 ft. A fine bedding or border dahlia, free, early and profuse. This creamy white flower differs from the Century type by having small quilled petals of the same color covering the entire centre.

\section{Single Dahlias}

AUTUMN CENTURY (Bassett 76), g, Bloom 41/2, Bush 5 ft. A beautiful autumn tint, delicate madder lake, shading yellow at centre.

DAHLIADEL CENTURY (Dahliadel 80), g, Bloom 5, Bush $5 \mathrm{ft}$. It is all that can be asked for in a white single dahlia. Its size, form, habit of growth, productiveness and clear, pure white color put it far ahead of anything else.

GARNET POINSETTIA (Peacock 84), 1929, g e, Bloom 7, Bush $6 \mathrm{ft}$. Rich, glowing garnet with a brilliant, glistening sheen. Large blooms of poinsettia form are held on long, stiff stems on strong plants, producing profusely.

$\$ 1.00$

JAMES WELLER (Peacock 82), $g$ e, Bloom 6, Bush $51 / 2$ ft. Effective because of its color combination of rich golden yellow with central zone of each petal soft rosy red. Large, wellformed blooms are held erect on long, stiff stems. Early and continuous blooms.

PURITY (Peacock 84), g e, Bloom 7, Bush 6 ft. Pure white, perfectly formed, on long, stiff stems. Petals are broad and heavy and slightly recurved. A good grower and bloomer. $\quad .50$

NEWPORT WONDER (Robertson 84), g, Bloom 6, Bush 51/2 ft. A very popular and artistic dahlia. Petals pointed and slightly twisted. Color, rose pink with a gold suffusinn.

SCARLET CENTURY (Peacock 80), $\mathrm{g}$ e, Bloom 5, Bush $5 \mathrm{ft}$. Bright, glowing scarlet on erect stems. Good grower, free bloomer, with petals evenly placed.

TANGO (Dahliadel 79), g, Bloom 51/2, Bush 6 ft. A lively autumn tint, cadmium yellow, shaded scarlet orange.

\section{Collarette Dahlias}

GEANT DE LYON (Vilmore 89), g e, Bloom 5, Bush $4 \mathrm{ft}$. Rich, velvety carmine maroon, with long, cream color petals. Free, early flowering on erect stems. The prettiest of all collarette dahlias. 


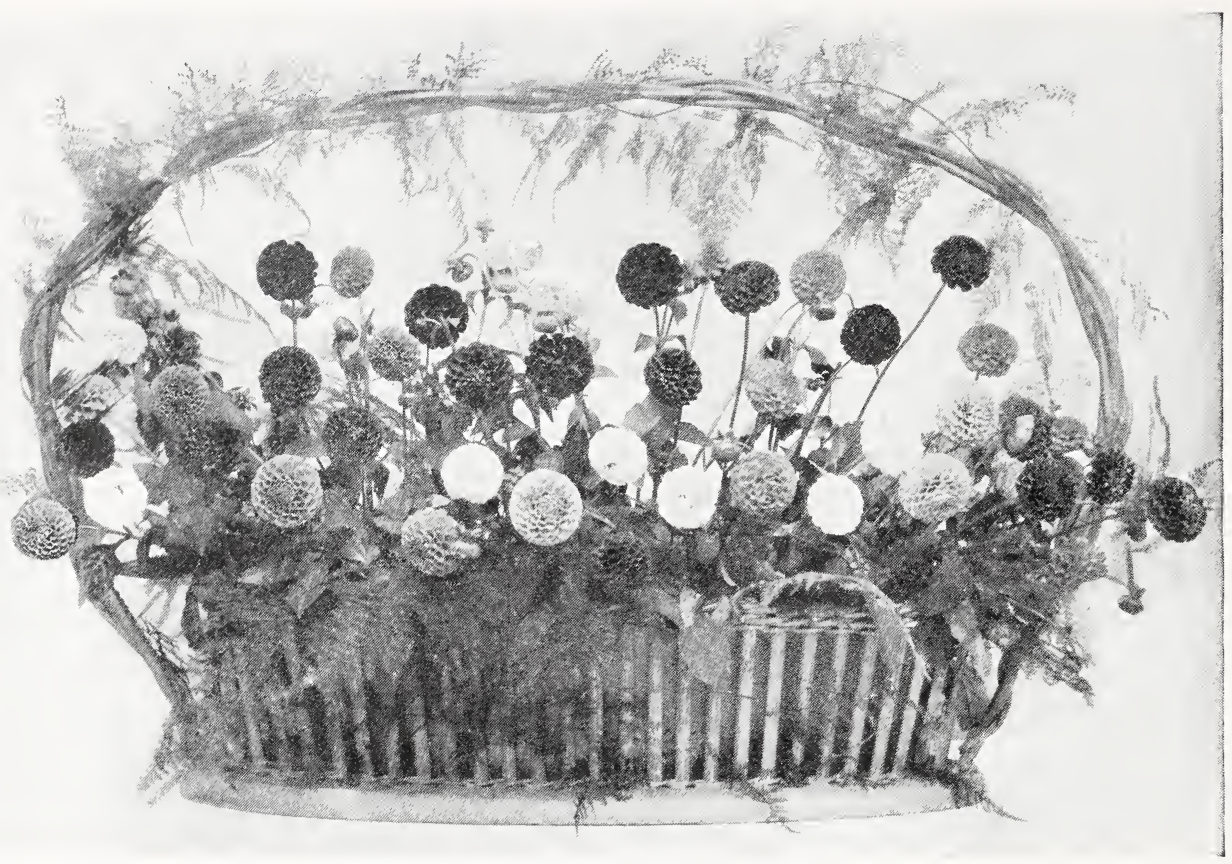

\section{POMPON DAHLIAS}

\section{INTRODUCTIONS}

BOB WHITE (Dahliadel 89), 1930, c $g$ e, Bloom 11/2, Bush 2 ft. This dahlia can best be described as a white Johnny. It is milk white, having just a cast of yellow when opening. Bush is low and spreading, with blooms on long stems, literally all over the bush, making it ideal for bedding as well as the right form for exhibiting, for it is as deep as its diameter.

Tubers, $\$ 1.00 ;$ Plants, $\$ 1.00$

DOT (Dahliadel 89), 1930, c g e, Bloom 11/2, Bush 3 ft. We have here a pure white pom on perfect stems, a strong grower, early bloomer and a beautiful bush in bloom. This is the best all-around white Pompon you can grow. Bob White will probably win on the exhibition table, where the smallest perfect bloom reigns supreme, but as a cut flower for decorating or in the garden, Dot is the best so far introduced.

Tubers, $\$ 1.00 ;$ Plants, $\$ 1.00$

\section{GENERAL LIST}

AIMEE (Boston 85), c g e, Bloom 11/4, Bush 21/2 ft. A popular tiny orange cadmium shaded apricot, on long stems

.50

ATOM (Edymel 88), c $g$ e, Bloom 11/4, Bush $2 \mathrm{ft}$. One of the best early and profuse bloomers of perfect form. Color, fiery red.

Tubers, .75; Plants, .50

BELLE OF SPRINGFIELD (83), c g e, Bloom 11/4, Bush $2 \mathrm{ft}$. One of the smallest and most popular on the exhibition table. Soft red.

BRONZE BEAUTY (78), c g, Bloom 13/4, Bush 3 ft. Beautiful golden apricot; a free bloomer, good for cutting.

DARKSOME (Alexander 80), $g$ e, Bloom 13/4, Bush 41/2 ft. One of the best real dark red or maroon.

DEE DEE (Estes 85), c g e, Bloom 11/4, Bush 31/2 ft. One of the daintiest and smallest. Pale lilac, fine for exhibition. 


\section{POMPON DAHLIAS-Continued}

ELFIN (75), c g, Bloom $13 / 4, B u s h ~ 31 / 2 f t$. Light primrose yellow. A good grower and free bloomer.

ELIZABETH (82), $g$ e, Bloom 11/2, Bush 21/2 ft. Lemon yellow, heavily tipped carmine. Fine form and good stems.

EUREKA (82), $g$ e, Bloom $13 / 4$, Bush $3 \mathrm{ft}$. Yellow cadmium with carmine shadings at tips with occasional white petals. Some flowers all-white. Can be rightly called variegated. .35

GERTRUDE (Salbach 85), c g e, Bloom 11/2,Bush $3 \mathrm{ft}$. One of the brightest dahlias grown Color, glowing carmine, of good form on good stems. Tubers, .75; Plants, .50

JESSICA (Turner 80), c $g$ e, Bloom 11/2, Bush $3 \mathrm{ft}$. Yellow, tipped red. Very free and early bloomer with good stems.

.50

KLEINE DOMITEA (78), c $g$ e, Bloom $13 / 4$, Bush $3 \mathrm{ft}$. Bright orange buff. A good grower and early bloomer.

LITTLE BELLE (78), c g, Bloom 11/2, Bush 41/2 ft. Very fine mauve pink with long and erect stems.

LITTLE DAVID (Twitchett 85), c g e, Bloom 11/4, Bush $2 \mathrm{ft}$. A small, perfectly formed russet orange pom. Free bloomer and fine for cutting and exhibiting.

.50

LITTLE EDITH (90), c g e, Bloom 11/4, Bush $2 \frac{1 / 2}{f t}$. As perfect a pom as you can wish for. Color, primrose yellow, tipped bright carmine.

MIDGET (West 80), c g e, Bloom 11/2, Bush $3 \mathrm{ft}$. Salmon suffused with violet. Good form. .50 ROSEA (Keynes 84), c g e, Bloom 13/4, Bush 21/2 ft. Perfect form for exhibition. Rosy lavender. Small and distinctive.

SNOWCLAD (80), $\boldsymbol{c} g$ e, Bloom $1 \frac{1}{2}$, Bush $3 \mathrm{ft}$. One of the best all-around pure whites. Free, early bloomer.

SUNNY DAYBREAK (Keynes 87), c g e, Bloom 11/2, Bush $21 / 2 \mathrm{ft}$. Lemon yellow, heavily tipped cardinal. Flowers of good form.

SUNSET (Keynes 84), c $g$ e, Bloom 1 1/4, Bush $2 \frac{1}{2} \mathrm{ft}$. Fine small exhibition variety, bright orange. Very popular.

.50

YELLOW GEM (McWhirter 83), c g e, Bloom 11/2, Bush $3 \mathrm{ft}$. Clear canary yellow, of fine form.

ALL THE ABOVE VARIETIES ARE THE SAME FORM AS ILLUSTRATION

\section{Dahlia Tubers That Will Winter}

First, sidestep the varieties that are known to be poor root makers.

Second, plant only stock that has been properly grown without previous forcing.

Third, fertilize so that your plants will have a balanced ration, namely, nitrogen in manures, humus or bone meal; and phosphoric acid in acid phosphate or bone meal, and potash in wood ashes, sulphate, or muriate of potash.

Fourth, cultivation is worth more than watering for healthy plant growth. Water thoroughly only when necessary (not more than once a week in a dry spell), but cultivate once a week throughout the season, until the middle of September, then stop. This check will help materially in ripening the tubers.

Selected stock in either green plants or tubers properly fertilized, watered and cultivated will produce wonderful blooms, and the tubers will have every chance of wintering. A complete starch formation is essential for the proper wintering of a dahlia tuber, and the above suggestions are essential.

DIGGING AND STORING. After the first black frost, cut off the tops at the ground and allow to stand a few days to bleed out. Then dig with a garden fork. Care should be exercised not to break the tuber necks. Cut the stalk back again to about 2 inches above the crown. Then by tapping on the cut stalk endwise with a light instrument, most of the dirt will free without injury to the necks of the tubers. Dry in the sun a few hours, and your clumps are ready to store. A root or white potato cellar is preferable with a temperature of about 40 degrees. In this they need no protection or covering. The average house cellar is too dry and hot, and in such conditions the clumps should be placed in the coolest part and packed upside down in a box in dry sand, ashes or preferably ground Peat Moss.

After the tubers are stored a month, it is well to look them over, trim out any portion showing rot and dip all the fresh cuts in equal parts of hydrated lime and flowers of sulphur, and pack them back again as before. Should the tubers show signs of shriveling, place dampened Peat Moss over the top of the box to prevent further drying.

Dahlia tubers air dried and so packed should keep well until spring with no further handling, providing they were grown properly, well ripened and not frosted. 


\section{DAHLIA GROWERS' SUPPLIES}

DAHLIADEL PLANT FOOD-Made especially for dahlias, of the highest grade materials, for the production of fine flowers and strong tubers, and so blended to have a balanced food available as needed by the plant. Good also for all outdoor flowers and vegetables. A very economical fertilizer.

Directions: Spring application, 3 to $6 \mathrm{lbs}$. to each 100 square feet. August application, 3 to $4 \mathrm{lbs}$. This may be divided into three applications, but not over $10 \mathrm{lbs}$. to ten hills should be applied during a season.

Price, F. O. B. factory in Philadelphia, 50 lbs., $\$ 3.00 ; 100$ lbs., $\$ 5.50 ; 200$ lbs., $\$ 10.00 ;$ ton, $\$ 90.00$. We can ship in the States of New Jersey, Pennsylvania, Delaware, and New York only, owing to State regulations.

DOMESTIC PRUNING SHEARS-Double cutter; works especially well for dividing tubers. The steel in these shears stands up better in sand and dirt than any shear we have found. For general pruning we find them very satisfactory. Postpaid, $\$ 3.25$.

IMPORTED PRUNING SHEARS-Made especially for root cutting. Double cutting blades curved and pointed, making them the best type for dividing dahlia clumps. This is the shear we are using for all our dividing and trimming. Suitable for general pruning as well. Postpaid, \$4.00.

PYRETHROL-A non-poisonous Pyrethrum Insecticide, effective on all insect life, especially Japanese beetles, and not injurious to animals or plants. Will not burn or stain foliage or flowers. Directions for application sent with order. Postpaid, including the fourth zone, $1 / 2 \mathrm{lb} ., \$ .60 ; 2 \mathrm{lbs}$., $\$ 1.60 ; 10$ lbs., $\$ 6.35$.

BRASS SPRAYER GUNS-Continuous spray, one-quart size. Suitable for spraying Pyrethrol, nicotine or soap sprays, but not for sprays containing lime or solids. Postpaid, including the fourth zone, $\$ 2.15$.

DAHLIADEL NICOTONE-A 3\% nicotine dust. 5 lbs., $\$ 1.50 ; 25$ lbs., $\$ 5.75$ by express, collect. By parcel post, prepaid, including the fourth zone, $1 \mathrm{lb}$., $\$ .50 ; 2$ lbs., $\$ .90 ; 5$ lbs., $\$ 1.75$. For distant shipments, include additional postage.

DAHLIADEL DUSTING OUTFIT-Consisting of one pump-type duster with extension spout for dusting small plants without stooping, and $1 \mathrm{lb}$. Dahliadel Nicotone. Postpaid, including the fourth zone, $\$ 2.10$, with $2 \mathrm{lbs}$. of nicotine, $\$ 2.50$. For distant shipments, include additional postage.

VERMOREL "ORANGE" DUSTER-The best knapsack duster we have found for applying nicotine dust. F. O. B. Vineland. Shipping weight, 18 lbs. Price, $\$ 15.00$.

MODERN DAHLIA CULTURE-By W. H. Waite. Written to meet the needs of the novice and to interest the expert. 126 pages of clear type, well illustrated. Cloth binding. The best book to date. $\$ 1.60$ postpaid.

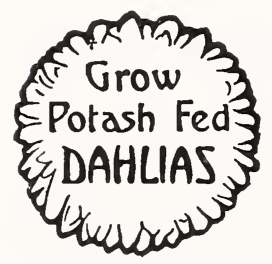

TRADE MARKS
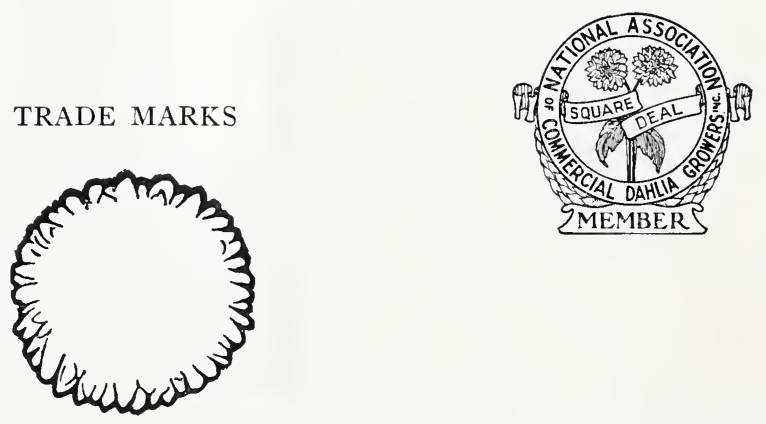

Potash Fed DAHLIAS

DAHLIADEL NURSERIES 


\title{
DAHLIADEL COLLECTIONS
}

\section{DAHLIADEL TRIO}

\author{
$\$ 2.50$ \\ Emma Marie

\section{A-INTRODUCTORY COL.} \\ $\$ 1.00$ \\ Value $\$ 3.00-\$ 4.00$ \\ 6 tubers tagged, all different and fine- \\ named varieties. This collection is made \\ up of a good assortment of colors, no \\ singles and a wonderful value.
}

Value $\$ 4.00$

Eastern Star

Casper G. Ware

\section{BEGINNERS' SURPRISE COLLECTION}

$\$ 2.00$

Value $\$ 6.00$ to $\$ 8.00$

12. tubers tagged, all different and fine-named varieties not used in Collection A. This collection is a good assortment of colors and types, no singles. A very popular Dahliadel collection for each year, it is better, as finer varieties find their way into it.

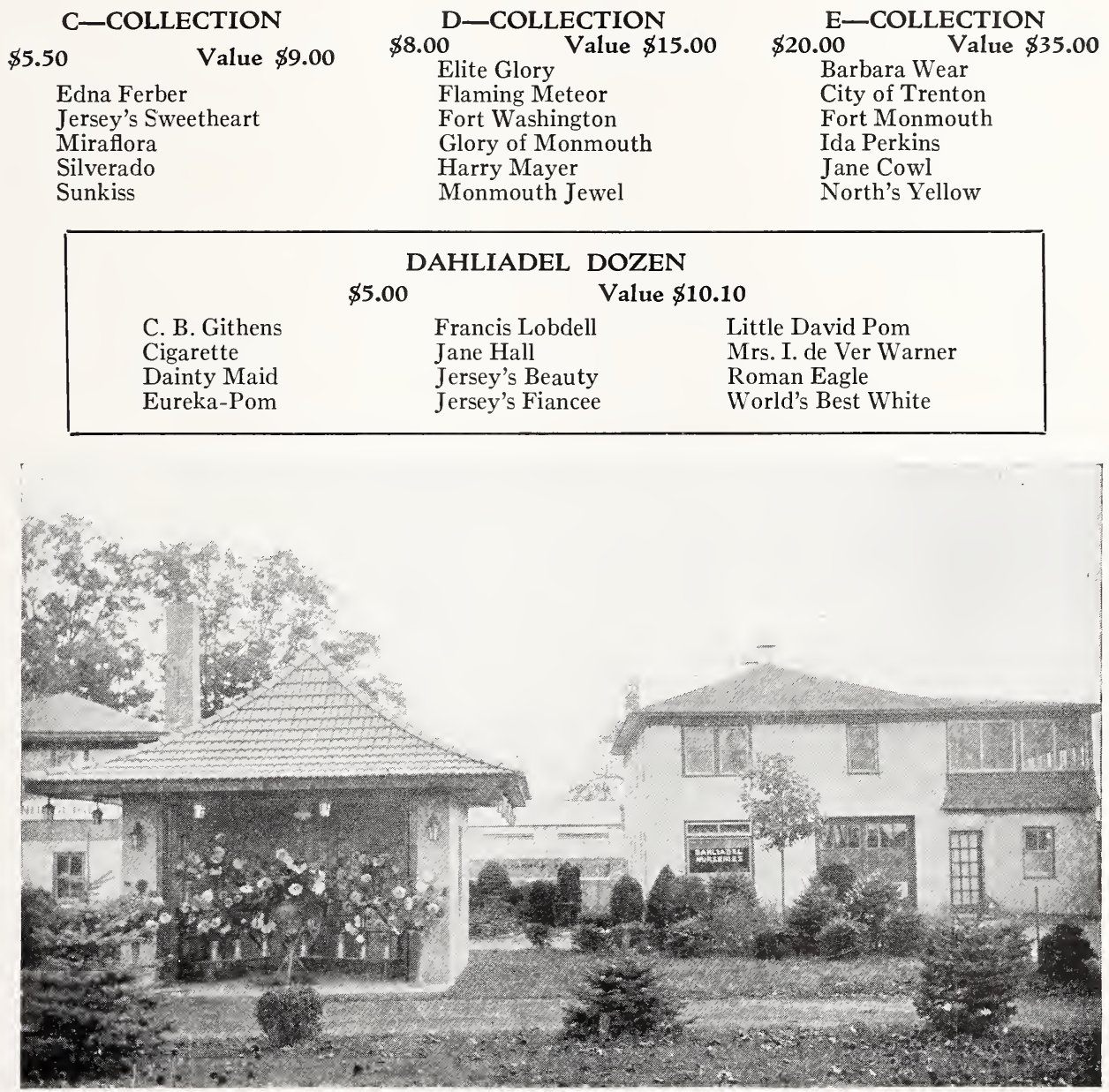

DAHLIADEL NURSERIES

If you have never had the pleasure of visiting our trial grounds, you should see them during September or October, when a wealth of blooms and a riot of color beckon a welcome at Dahliadel Nurseries. Old and new friends always welcome. 


\section{$\mathbb{N D E X}$}

You will find some of your old friends listed in the index without page or folio. In most cases these varieties are so well known descriptions are omitted from the catalog.

We will have most of the Introductions for 1930 and will be glad to quote on your list, but we prefer to grow these varieties a year before cataloging them.

ABBREVIATIONS USED IN INDEX.-A-Anemone. B-Ball. Coll-Collerette. C-Cactus, Incurved, Recurved or Straight. S-C-Semi-Cactus, formerly Hybrid Cactus. FD-Formal Decorative, formerly Decorative. ID-Informal Decorative, formerly Hybrid Decorative. MD-Miniature Decorative. P-Peony. PomPompon. S-Single.

\begin{tabular}{|c|c|c|c|c|c|c|c|}
\hline \multicolumn{2}{|c|}{ Page } & $\frac{\text { Tubers }}{\not \ddot{0.75}}$ & $\frac{\text { Plants }}{\$ 5.00}$ & \multicolumn{2}{|c|}{ Page } & 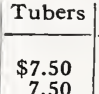 & $\begin{array}{c}\text { Plants } \\
\$ 3.75 \\
3.75\end{array}$ \\
\hline $\begin{array}{r}43 \\
32 \\
32 \\
7 \\
18 \\
33 \\
37 \\
15 \\
10 \\
42 \\
3 \\
41 \\
24 \\
10 \\
26 \\
37 \\
33 \\
19 \\
15 \\
35 \\
17 \\
42 \\
4 \\
31 \\
38 \\
9 \\
3 \\
35 \\
13 \\
43 \\
42 \\
15\end{array}$ & 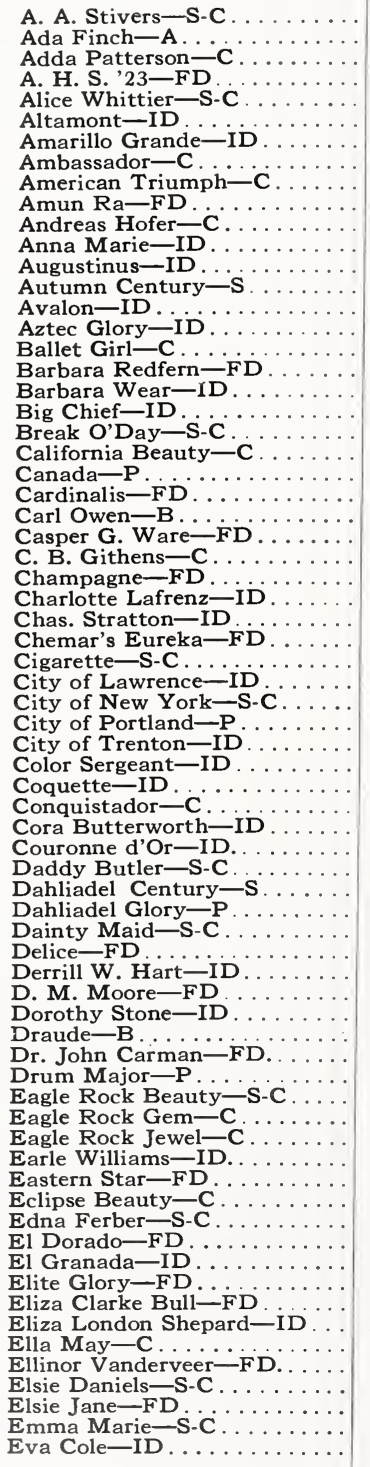 & 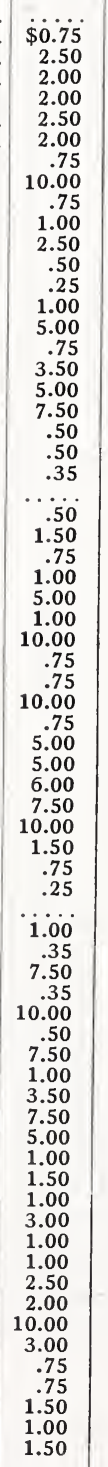 & 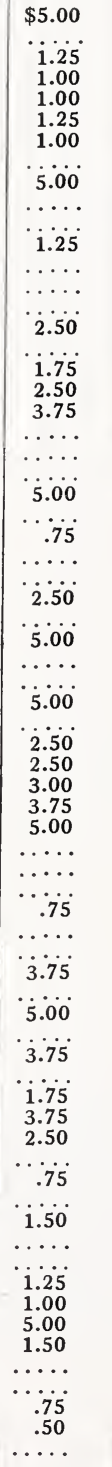 & 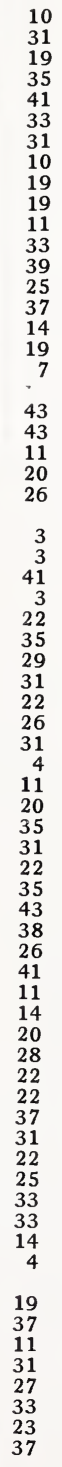 & 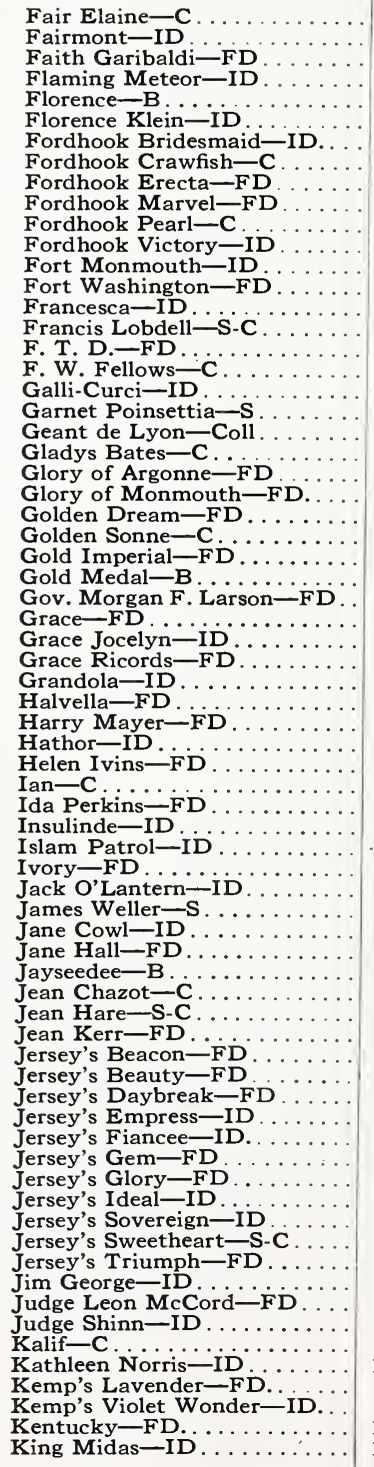 & 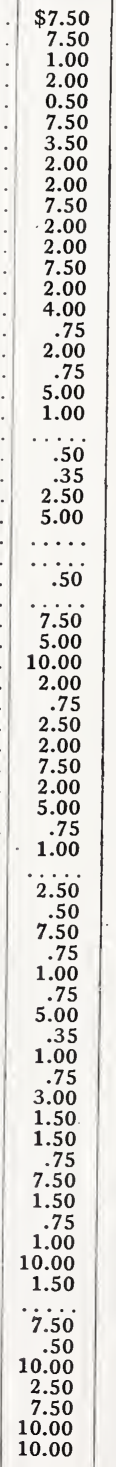 & 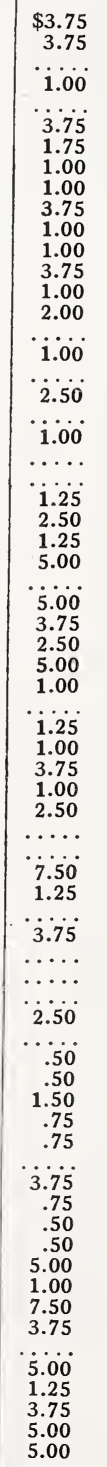 \\
\hline
\end{tabular}




\section{INDEX-Continued!}

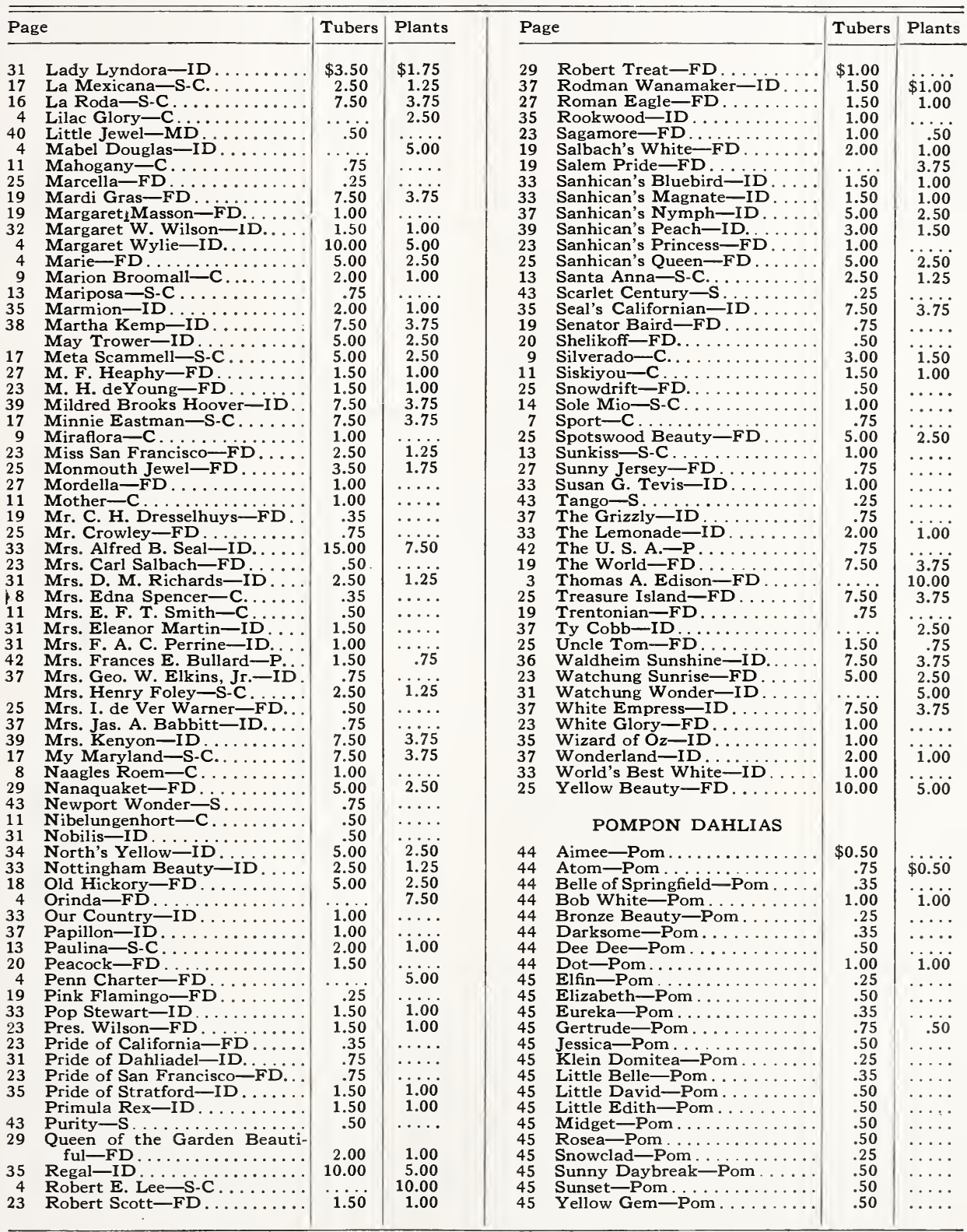

Here's hoping for the biggest and best year ever for all the dahlia shows. Even though we have experienced a couple of trying seasons, there have been some wonderful exhibits all over the country, and this year should be even greater. 


\section{F R E E}

YOU MAY SELECT YOUR OWN COMPLIMENTARY TUBERS from the following list on orders for DAHLIA TUBERS AND PLANTS from this catalog, except on collections. On each dollar you are allowed $25 \mathrm{c}$ toward any variety in this list. For example, on an order of $\$ 6.00$ worth of tubers or plants you may select $\$ 1.50$ worth from the following list free, or a $\$ 2.00$ variety by paying $50 \mathrm{c}$ additional.

Amun $\mathrm{Ra} \ldots \ldots \ldots \ldots .75$

Avalon ............ 1.00

Casper G. Ware....... 1.50

City of Trenton...... 5.00

Eastern Star ........ 150

E. B. Roberts......... . .75

Ellinor Vanderveer .... . .75
Faith Garibaldi ......\$1.00

Grandola .......... 2.00

Harry Mayer ......... 2.50

Jersey's Sovereign .... .75

Kemp's Lavender ....... 2.50

Klein Domitea Pom.... .25

Marcella .......... .25
Margaret W. Wilson....\$1.50

Neatness Pom ....... .50

Robert Scott ......... 1.50

Sanhican's Bluebird .... 1.50

Sanhican's Princess .... 1.00

Snowclad Pom ....... .25

Snowdrift $\ldots \ldots \ldots \ldots \ldots . .50$

\section{POSITIVELY NO FREE TUBERS ON COLLECTIONS OR SPECIAL OFFERS}

DAHLIAS of QUALITY and DISTINCTION mean for you QUALITY tubers with all the health and vitality a well-grown tuber should have, regardless of cost of production, and DISTINCTION by growing only the worthwhile varieties of the bright and pleasing shades and colors. Our forty acres of healthy stock and 17,000 square feet of floor space completely equipped for growing, storing and shipping dahlias await your needs.

\section{OUR GUARANTEE}

All dahlia tubers and plants are guaranteed healthy and true to name to the extent of replacement with true stock. Tubers that fail to start in three weeks will be replaced upon their return. POTASH FED DAHLIAS have given such universal satisfaction the past season that we are going one step further and guarantee Dahliadel 1930 Introductions to prove entirely satisfactory to the extent of replacement with the same variety or one of any other of equal value from the following season's catalog. Satisfaction and safe delivery guaranteed.

Orders will be filled with strong, field-grown root divisions unless green plants are specified. We will notify you if unable to supply any variety, as we do not substitute. Six of one variety for the price of five.

\section{TERMS AND DELIVERY}

CASH WITH ORDER. Stamps accepted up to $\$ 3.00$; above that amount, check, money order or cash by registered mail. Tubers will be sent April 15th to May 15th by parcel post prepaid, unless shipment is C. O. D., in which case the customer pays the C. O. D. charges. Shipments to sections where plantings are at a different time will be made accordingly.

WARNING. Do not send cash by mail unless you have it registered.

NOTICE ON GREEN PLANT SHIPMENTS. Plants will be shipped from April 15th to June 15th, but cannot be sent C. O. D., as this causes delay. When tubers and plants are ordered together, tubers will be held and shipped with the plants unless otherwise specified. For shipments of 200 miles or over, we recommend plants should travel parcel post, "Special Delivery." For this please add $25 \mathrm{c}$ to your remittance. We pay all regular postage.

We guarantee plants as well as tubers to arrive in good condition, but cannot guarantee plants if shipped over 200 miles unless sent "Special Delivery."

\section{DAHLIADEL NURSERIES}




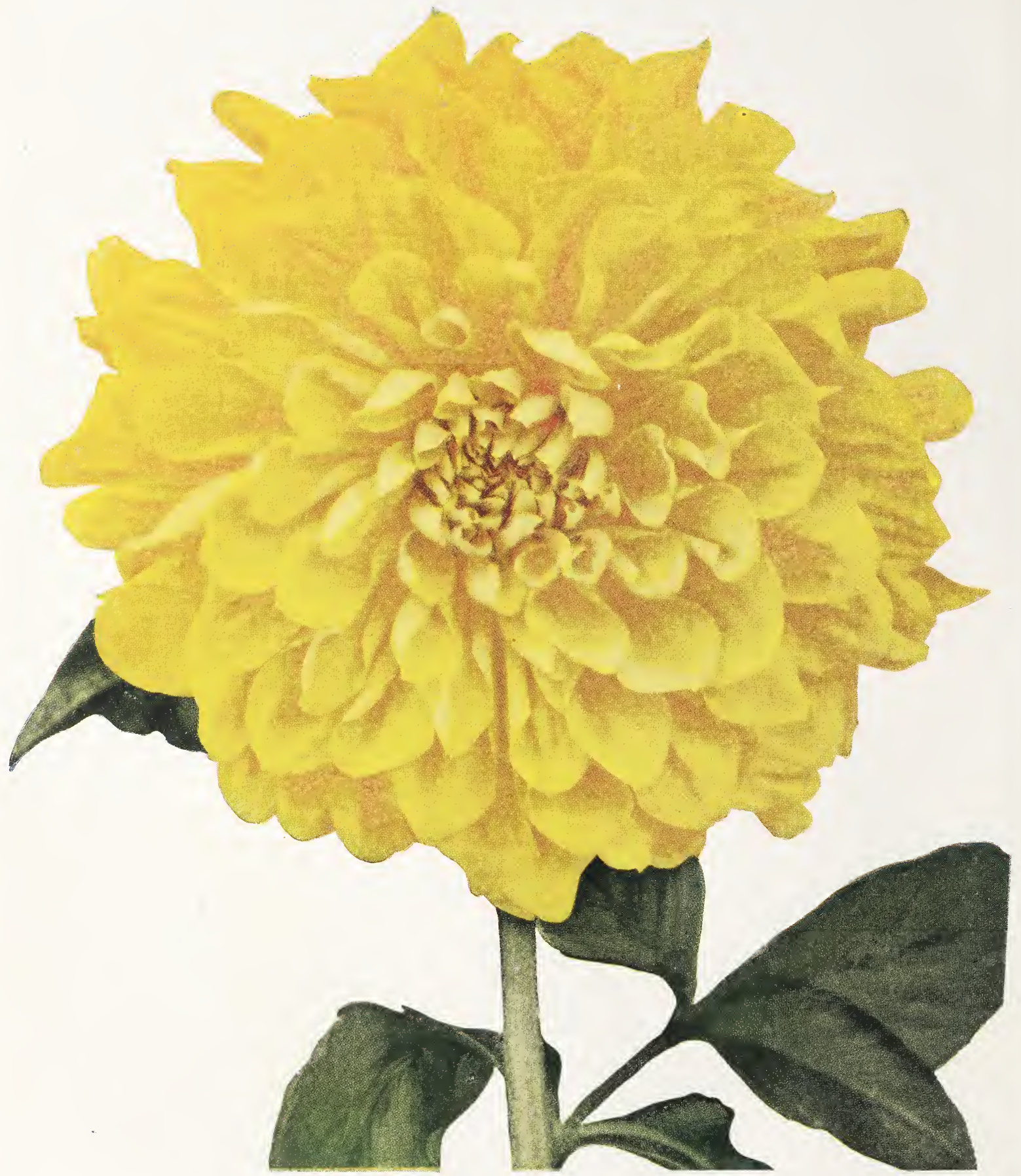

EASTERN STAR (Dahliadel 85), c ge, Bloom $9 x 4$, Bush $5 \mathrm{ft}$. The color reproduction cannot portray the lively tones of this wonderful dahlia, but does give you a general idea. Color, a saffron yellow with old gold shadings. Flowers of great substance and good keeping qualities, with full centres held on strong, erect stems. Excellent bush growth and free flowering. Eastern Star has a wonderful prize-winning record and is one of the finest exhibition dahlias you can grow. D. S. of N. J. Cert.

Tubers, \$1.50; Plants, .75 


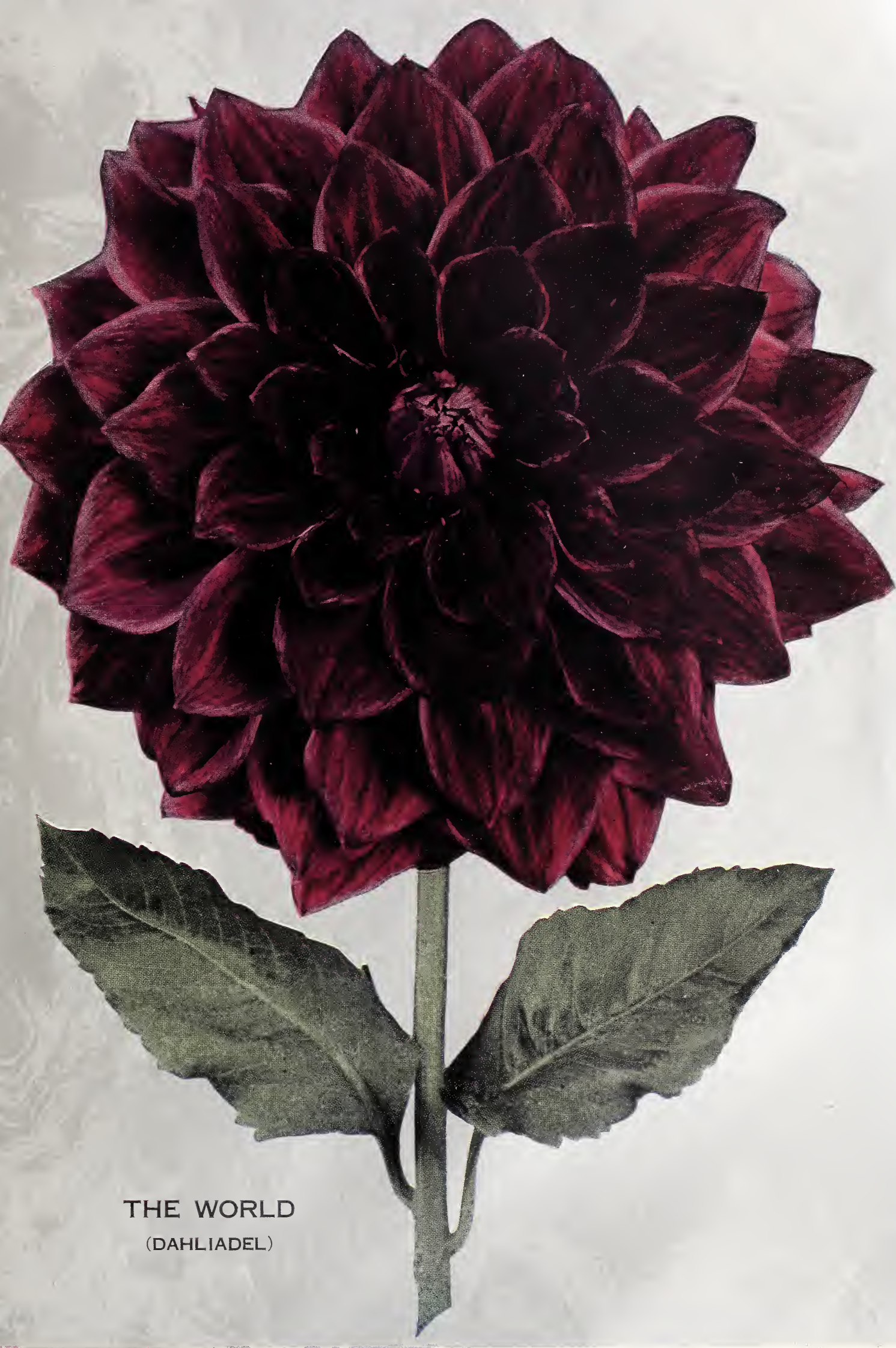




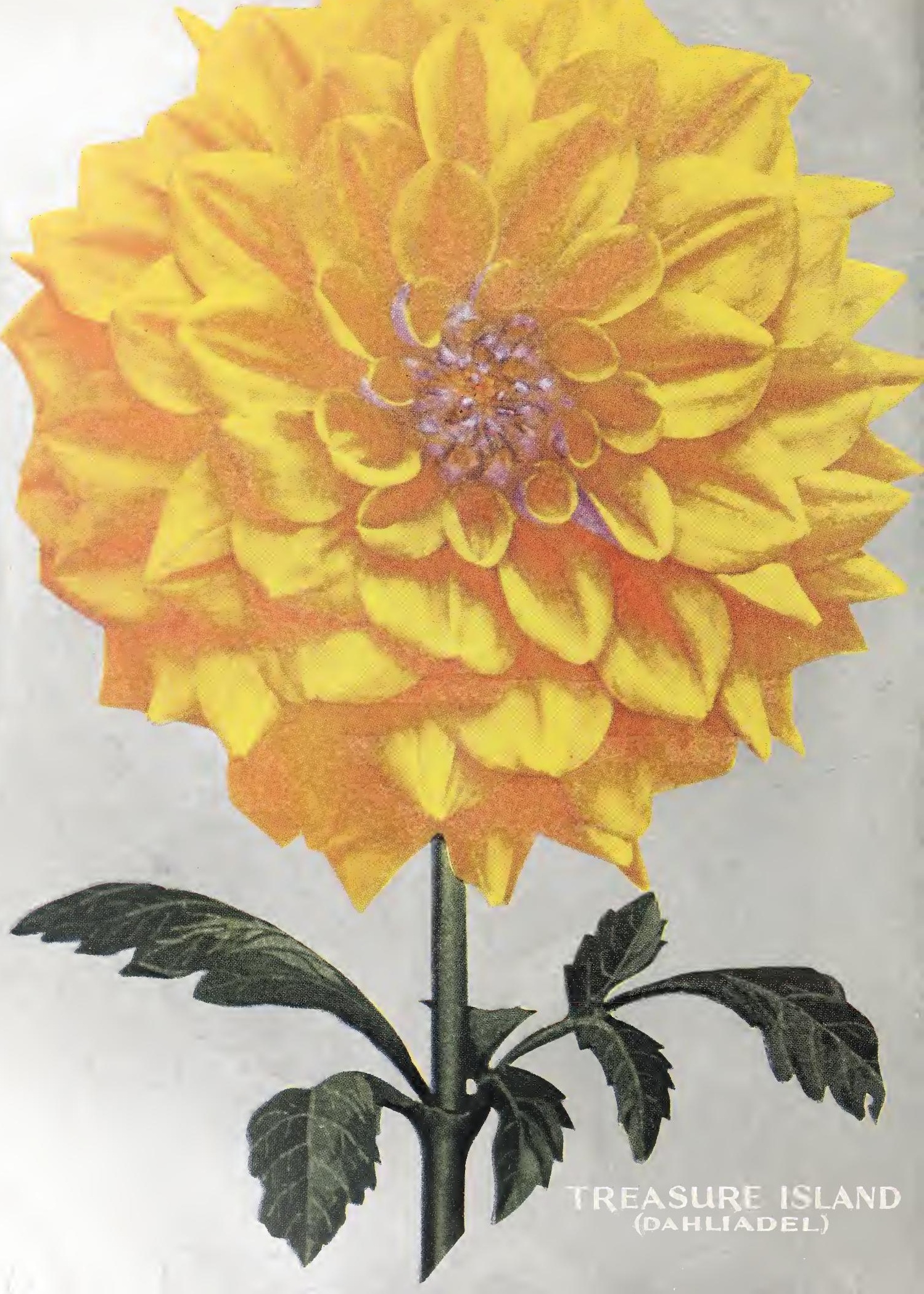

